Supporting Information For

\title{
Synthesis of Anhydroryanodol
}

\author{
Kang Du, ${ }^{\dagger}$ Matthew J. Kier, ${ }^{\dagger}$ Zachary D. Stempel, ${ }^{\dagger}$ Valer Jeso, ${ }^{\dagger}$ Arnold L. Rheingold, ${ }^{\ddagger}$ \\ Glenn C. Micalizio*† \\ ${ }^{\dagger}$ Department of Chemistry, Burke Laboratory, Dartmouth College, Hanover, NH 03755 \\ ${ }^{\ddagger}$ Department of Chemistry, University of California, San Diego, La Jolla, CA 92093. \\ glenn.c.micalizio@dartmouth.edu
}

\section{Table of Contents}

1. Materials and Methods

2. Experimental Procedures

A: Synthesis of Substrate $\mathbf{1 2}$ for Annulation $\quad$ S3

$\begin{array}{ll}\text { B: Ti-mediated Oxidative Annulation en route to } \mathbf{1 8} & \text { S7 }\end{array}$

$\begin{array}{ll}\text { C: Synthesis of Anhydroryanodol } 25 & \text { S11 }\end{array}$

3. NMR Data Comparison of Anhydroryanodol between literature and this Report $\quad$ S19

4. NMR Data $\quad$ S21

5. X-ray Data of Compound $14 \quad$ S46

$\begin{array}{lr}\text { 6. References } & \text { S72 }\end{array}$ 


\section{Materials and Methods}

All reactions were conducted in flame-dried glassware under a nitrogen atmosphere with dry solvents, unless otherwise noted. All reagents and starting materials were purchased from commercial sources and used as supplied, unless otherwise indicated. Anhydrous diethyl ether $\left(\mathrm{Et}_{2} \mathrm{O}\right)$, tetrahydrofuran (THF), toluene (PhMe), dimethylformamide (DMF) and dichloromethane (DCM) were obtained by Glass Contour Solvent Purification System. 1,2-dichloroethane (DCE) and acetonitrile $\left(\mathrm{CH}_{3} \mathrm{CN}\right)$ were purchased from Acros. Benzene was purchased from Sigma-Aldrich. Bis(benzonitrile)palladium(II)chloride $\left(\mathrm{Pd}(\mathrm{PhCN})_{2} \mathrm{Cl}_{2}\right)$, Wilkinson's and Crabtree's Catalysts were purchased from Strem Chemicals. Hoveyda-Grubbs (II) Catalyst was purchased from SigmaAldrich. $\mathrm{Cp}_{2} \mathrm{TiCl}_{2}$ and $t-\mathrm{BuOOH}$ (ca $5.5 \mathrm{~N}$ in nonane) were purchased from Sigma-Aldrich. Titanium isopropoxide $\left(\mathrm{Ti}(\mathrm{O} i-\mathrm{Pr})_{4}\right)$ was purchased from Acros, and titanium isopropoxide was distilled before use. $i-\mathrm{PrMgCl}(2.0 \mathrm{M}$ in THF) was purchased from Sigma-Aldrich and was titrated against salicylaldehyde phenylhydrazone. ${ }^{1} n$-BuLi (2.5 M in hexanes) was purchased from Sigma-Aldrich and titrated against $\mathrm{N}$-benzylbenzamide, Lithium bis(trimethylsilyl)amide (LiHMDS, 1.0 M in THF) and potassium bis(trimethylsilyl)amide (KHMDS, 0.5 M in toluene) were purchased from SigmaAldrich. Yields refer to chromatographically and spectroscopically $\left({ }^{1} \mathrm{H} N M R\right)$ homogeneous materials, unless otherwise stated. Flash column chromatography was performed on the Biotage ${ }^{\circledR}$ Automated Liquid Chromatography System Isolera One ${ }^{\circledR}$ using Biotage ${ }^{\circledR}$ SNAP KP-Sil 10-100 g silica gel cartridges, Biotage ${ }^{\circledR}$ SNAP HP-Sphere ultra 10-25 g and Biotage ${ }^{\circledR}$ Sfär Silica HC 5-25 g silica gel cartridges or by using Sorbent Technologies ${ }^{\mathrm{TM}}$ silica gel, $60 \AA$ (60-43 $\mu \mathrm{m}$ particle size) as stated. TLC analyses were performed on EMD TLC Silica gel $60 \mathrm{~F}_{254}$ Glass Plates and the spots were visualized by UV-light $\left(254 \mathrm{~nm}\right.$ ) or an aqueous solution of $\mathrm{KMnO}_{4}$ or $p$-anisaldehyde. ${ }^{1} \mathrm{H} \mathrm{NMR}$ data were recorded on Bruker Avance III 500 (TBI probe) and $600 \mathrm{MHz}$ (BBFO probe) spectrometer with calibration of spectra to residual $\mathrm{CDCl}_{3}(7.26 \mathrm{ppm}), \mathrm{CD}_{3} \mathrm{OD}$ (3.31 ppm). ${ }^{13} \mathrm{C} \mathrm{NMR}$ data were recorded at $150 \mathrm{MHz}$ on $600 \mathrm{MHz}$ spectrometer (BBFO probe) with calibration to the central line of $\mathrm{CDCl}_{3}$ (77.16 ppm), $\mathrm{CD}_{3} \mathrm{OD}(49.00 \mathrm{ppm})$. Infrared spectra were recorded on a JASCO FT/IRM4100 Fourier Transform Infrared Spectrometer. HRMS (ESI or EI) analyses were performed at the Mass Spectrometry Laboratory of University of Illinois at Urbana-Champaign. X-ray analysis data was collected from Crystallography Facility at University of California San Diego. All compounds purified by chromatography were sufficiently pure for use in further experiments, unless indicated otherwise. For abbreviations, PMB: Para-methoxybenzyl, NBS: $N$-bromosuccinimide, DMSO: dimethyl sulfoxide DDQ: 2,3-dichloro-5,6-dicyano-1,4-benzoquinone, TPAP: tetrapropylammonium perruthenate, NMO: $\mathrm{N}$-methylmorpholine- $\mathrm{N}$-oxide, $\mathrm{DI} \mathrm{H}_{2} \mathrm{O}$ : deionized water, TASF: tris(dimethylamino)sulfonium difluorotrimethylsilicate, $m$-CPBA: metaChloroperbenzoic acid. 


\section{Experimental Procedures}

\section{A. Synthesis of Substrate 12 for Annulation}

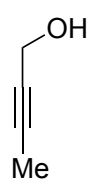

7

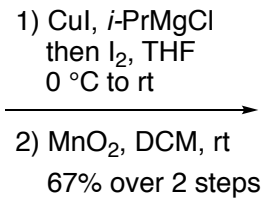

$67 \%$ over 2 steps<smiles>CC(C)/C(C=O)=C(/I)C(=O)Cl</smiles>

S1

A suspension of compound 7 ( $3.5 \mathrm{~g}, 0.050 \mathrm{~mol}, 1.0$ equiv.) and Cul ( $0.95 \mathrm{~g}, 5.0 \mathrm{mmol}, 0.10$ equiv.) in $50 \mathrm{~mL}$ THF was cooled to $0{ }^{\circ} \mathrm{C}$ and $i-\operatorname{PrMgCl}$ (1.89 M in THF, $63 \mathrm{~mL}, 0.12 \mathrm{~mol}, 2.5$ equiv.) was added dropwise over 30 minutes. The reaction solution was allowed to warm to rt and stirred overnight for ca. $24 \mathrm{~h}$ before it was cooled to $-78{ }^{\circ} \mathrm{C}$. A solution of iodine $(19 \mathrm{~g}, 0.075 \mathrm{~mol}, 1.5$ equiv.) in $40 \mathrm{~mL}$ THF was added dropwise. The mixture was warmed to $\mathrm{rt}$ and poured in a beaker containing $300 \mathrm{~mL}$ saturated aqueous $\mathrm{NaH}_{2} \mathrm{PO}_{4}$ solution, then $200 \mathrm{~mL}$ saturated aqueous $\mathrm{Na}_{2} \mathrm{~S}_{2} \mathrm{O}_{3}$ solution was added, followed by $200 \mathrm{~mL}$ ethyl ether. The suspension mixture was filtered through a fritted glass funnel. The organic layer was separated and the aqueous layer was extracted with ethyl ether (200 mL X 3). The combined organic layers were washed with brine, dried over anhydrous $\mathrm{MgSO}_{4}$, filtered through a fritted glass funnel, rinsed with $100 \mathrm{~mL}$ ethyl ether and the filtrate was concentrated in vacuo to yield a crude liquid. ${ }^{2}$

To a solution of the above crude material in $350 \mathrm{~mL}$ dichloromethane at $\mathrm{rt}$ was added manganese dioxide $(43 \mathrm{~g}, 0.50 \mathrm{~mol})$, the resulting black suspension was stirred at $\mathrm{rt}$ for ca. $72 \mathrm{~h}$. The suspension mixture was filtered through a fritted glass funnel, rinsed with $200 \mathrm{~mL}$ dichloromethane and the filtrate was concentrated in vacuo. Purification of the crude product by $\mathrm{SiO}_{2}$ flash column chromatography using $3 \%$ ethyl ether:97\% pentane as the eluent afforded 8.0 $\mathrm{g}$ of desired product $\mathbf{S 1}$ as a clear, colorless oil (67\% over 2 steps). Spectral data for S1: ${ }^{1} \mathrm{H}$ NMR $\left(600 \mathrm{MHz}, \mathrm{CDCl}_{3}\right) \delta 9.58(\mathrm{~d}, J=1.9 \mathrm{~Hz}, 1 \mathrm{H}), 3.18$ (heptd, $\left.J=7.1,1.9 \mathrm{~Hz}, 1 \mathrm{H}\right), 2.91(\mathrm{~s}, 3 \mathrm{H}), 1.15(\mathrm{~d}, J$ $=7.1 \mathrm{~Hz}, 6 \mathrm{H}) ;{ }^{13} \mathrm{C} \mathrm{NMR}\left(150 \mathrm{MHz}, \mathrm{CDCl}_{3}\right) \delta 200.0,145.4,119.9,33.9,29.0,20.1$; IR (thin film): 2961, $2932,2873,1749,1683,1584,1455,1381,1248,1040 \mathrm{~cm}^{-1}$; HRMS (ESI) calculated for $\mathrm{C}_{7} \mathrm{H}_{12} \mathrm{IO}$ $\left[\mathrm{M}+\mathrm{H}^{+}\right]$238.9933; found, 238.9931.<smiles>C/C(I)=C(\C=O)C(C)C</smiles>

S1

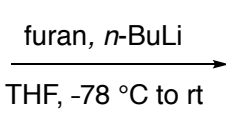

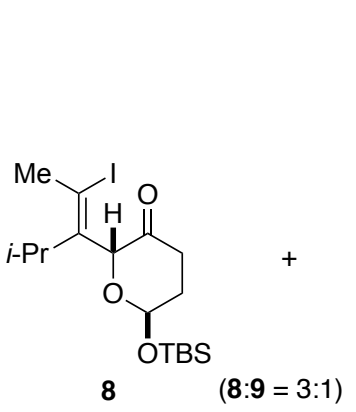

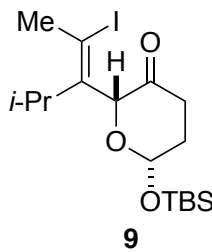

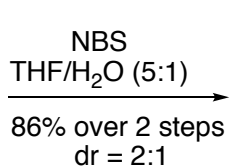

$\mathrm{dr}=2: 1$

S2<smiles>CC(C)/C(=C(/I)C(C)I)C1(O)O[C@H](O)C=CC1=O</smiles>

TBSOTf, lutidine DCM, -78 to $-40{ }^{\circ} \mathrm{C}$
$95 \%$<smiles>CCCCC1(C(=C(C)I)C(C)C)OC([Se-])C=CC1=O</smiles>

S4 


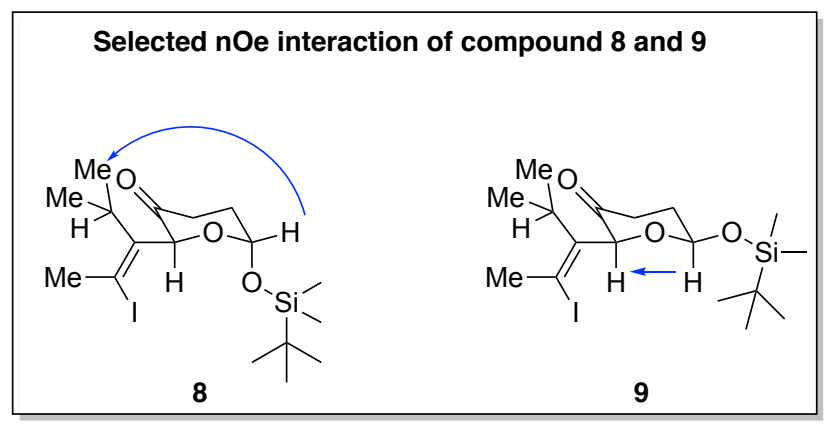

To a stirring solution of furan ( $5.1 \mathrm{~g}, 0.075 \mathrm{~mol}, 2.5$ equiv.) in $30 \mathrm{~mL}$ THF at $-78{ }^{\circ} \mathrm{C}$ was added $n$-BuLi (2.67 M in hexanes, $13 \mathrm{~mL}, 0.036 \mathrm{~mol}, 1.2$ equiv.) dropwise over 15 minutes. The resulting solution was stirred at $-78^{\circ} \mathrm{C}$ for 10 minutes, then slowly warmed to $\mathrm{rt}$ for ca. 30 minutes and cooled back to $-78{ }^{\circ} \mathrm{C}$. To this yellow suspension was added a solution of aldehyde $\mathbf{S 1}(7.2 \mathrm{~g}$, 0.030 mol, 1.0 equiv.) in $56 \mathrm{~mL}$ THF dropwise over 10 minutes, and the mixture was stirred at $78{ }^{\circ} \mathrm{C}$ until the reaction was judged to be complete by TLC analysis. The reaction was quenched by adding $100 \mathrm{~mL}$ saturated aqueous $\mathrm{NH}_{4} \mathrm{Cl}$ solution. The organic layer was separated and the aqueous layer was extracted with ethyl acetate $(50 \mathrm{~mL} \times 3)$. The combined organic layers were washed with brine, dried over anhydrous $\mathrm{Na}_{2} \mathrm{SO}_{4}$, filtered through a fritted glass funnel, rinsed with $20 \mathrm{~mL}$ ethyl acetate and the filtrate was concentrated in vacuo. The crude oil S2 (9.6 g) was used directly for the next step without further purification.

A stirring solution of $89 \%$ weight of above crude compound $\mathbf{S 2}(8.2 \mathrm{~g})$ in $160 \mathrm{~mL}$ THF and $32 \mathrm{~mL}$ DI water was cooled to $-15^{\circ} \mathrm{C}$, NBS $(5.3 \mathrm{~g}, 0.030 \mathrm{~mol})$ was added in one portion. The resulting suspension was stirred at $-15^{\circ} \mathrm{C}$ for 60 minutes. The reaction was quenched by adding $80 \mathrm{~mL} 10 \%$ aqueous $\mathrm{KI}$ solution and $80 \mathrm{~mL}$ saturated aqueous $\mathrm{Na}_{2} \mathrm{~S}_{2} \mathrm{O}_{3}$ solution. The organic layer was separated and the aqueous layer was extracted with ethyl acetate $(50 \mathrm{~mL} \times 3)$. The combined organic layers were dried over anhydrous $\mathrm{Na}_{2} \mathrm{SO}_{4}$, filtered through a fritted glass funnel, rinsed with $20 \mathrm{~mL}$ ethyl acetate and the filtrate was concentrated in vacuo. Purification of the crude product by $\mathrm{SiO}_{2}$ flash column chromatography using $20 \%$ ethyl acetate:80\% hexanes as the eluent afforded $7.4 \mathrm{~g}$ of compound S3 as an oil (86\% yield over 2 steps, 2.0:1 dr was checked with ${ }^{1} \mathrm{H}$ NMR after column chromatography).

To a stirring solution of compound S3 $(7.9 \mathrm{~g}, 0.024 \mathrm{~mol}, 1.0$ equiv.) in $210 \mathrm{~mL}$ dichloromethane at $-78^{\circ} \mathrm{C}$ was added 2,6 -lutidine ( $3.6 \mathrm{~g}, 0.034 \mathrm{~mol}, 1.4$ equiv.) followed by adding TBSOTf ( $7.6 \mathrm{~g}, 0.029 \mathrm{~mol}, 1.2$ equiv.) dropwise over 10 minutes. The reaction solution was stirred at $-40{ }^{\circ} \mathrm{C}$ for ca. 120 minutes. The reaction was quenched by adding $30 \mathrm{~mL}$ saturated aqueous $\mathrm{NaHCO}_{3}$ solution. The organic layer was separated and the aqueous layer was extracted with dichloromethane $(30 \mathrm{~mL} \times 2)$. The combined organic layers were washed with brine, dried over anhydrous $\mathrm{Na}_{2} \mathrm{SO}_{4}$, filtered through a fritted glass funnel, rinsed with $20 \mathrm{~mL}$ dichloromethane and the filtrate was concentrated in vacuo. Purification of the crude product by $\mathrm{SiO}_{2}$ flash column chromatography using $14 \%$ ethyl acetate: $86 \%$ hexanes as the eluent afforded $10 \mathrm{~g}$ of compound S4 as an oil (95\%).

To a flask equipped with a magnetic stir bar was added compound S4 $(30 \mathrm{~g}, 0.069 \mathrm{~mol}, 1.0$ equiv.) and $\mathrm{Rh}\left(\mathrm{PPh}_{3}\right)_{3} \mathrm{Cl}(3.1 \mathrm{~g}, 3.4 \mathrm{mmol}, 0.05$ equiv.).The reaction flask was evacuated with vacuum and backfilled with nitrogen 3 times. $300 \mathrm{~mL}$ benzene was added and hydrogen gas was bubbled into the solution for ca. 10 minutes. The resulting solution was stirred under hydrogen atmosphere at rt overnight. The mixture was filtered through a short pad of silica gel, washed with $25 \%$ ethyl acetate: $75 \%$ hexanes as the eluent to afford $22 \mathrm{~g}$ of mixture compounds $\mathbf{8}$ and $\mathbf{9}$ as an oil (73\% total for compounds 8 and $9,3: 1 d r$ was assigned by ${ }^{1} \mathrm{H}$ NMR analysis of the crude 
product mixture after silica plug). Further separation of compound $\mathbf{8}$ and it's diastereoisomer $\mathbf{9}$ by $\mathrm{SiO}_{2}$ flash column chromatography on a Biotage ${ }^{\circledR}$ SNAP Ultra HP-Sphere $50 \mathrm{~g}$ cartridge with gradient elution ( $2 \%-7 \%$ ethyl acetate in hexanes with 5\% DCM) afforded $12 \mathrm{~g}$ of compound 8 as an oil. ${ }^{i}$

Note: The ${ }^{1} H$ NMR spectra of this compound show broadened signals which were difficult to assign and integrate properly. Two signals were difficult to find and one signal was missing from the ${ }^{13} \mathrm{C} N \mathrm{NR}$. We attribute these observations to hindered rotation of the vinyl group about the dihydro-2H-pyran-3(4H)-one ring.

Spectral data for 8: ${ }^{1} \mathrm{H}$ NMR $\left(500 \mathrm{MHz}, \mathrm{CDCl}_{3}\right) \delta 5.45(\mathrm{t}, J=3.5 \mathrm{~Hz}, 1 \mathrm{H}), 5.22(\mathrm{br} \mathrm{s}, 0.8 \mathrm{H})$, $2.96(\mathrm{dq}, J=14.0,7.1 \mathrm{~Hz}, 1 \mathrm{H}), 2.73-2.63(\mathrm{~m}, 4 \mathrm{H}), 2.53(\mathrm{dt}, J=16.7,5.8 \mathrm{~Hz}, 1 \mathrm{H}), 2.47-2.35(\mathrm{~m}, 1 \mathrm{H})$, 2.01-1.93 (m, 1H), $1.07(\mathrm{~d}, J=7.1 \mathrm{~Hz}, 3 \mathrm{H}), 1.03(\mathrm{~d}, J=7.1 \mathrm{~Hz}, 3 \mathrm{H}), 0.93(\mathrm{~s}, 9 \mathrm{H}), 0.17(\mathrm{~s}, 3 \mathrm{H}), 0.15$ (s, 3H); ${ }^{13} \mathrm{C} \mathrm{NMR}\left(150 \mathrm{MHz}, \mathrm{CDCl}_{3}\right) \delta 207.5,144.3,101.3,91.3,34.3,31.3,31.1,30.9,25.9,21.8$, 20.4, 18.2, -4.1, -5.3; IR (thin film): 2955, 2924, 2857, 1729, 1461, 1254, 1128, 1036, 987, 837, $780 \mathrm{~cm}^{-1}$; HRMS (ESI) calculated for $\mathrm{C}_{17} \mathrm{H}_{31} \mathrm{O}_{3} \mathrm{NaSil}\left[\mathrm{M}+\mathrm{Na}^{+}\right]$461.0985; found, 461.0978.<smiles>C=C(C)CCC(C)=O</smiles>

8

10<smiles>C=C(C)CCC(=O)[C@H]1CC([OH2+])OC(/C(=C(/C)I)C(C)C)C1=O</smiles>

S5 (with enols)

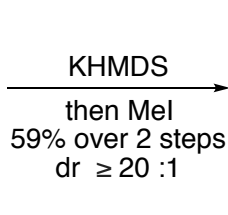<smiles>C=C(C)CCC(=O)C1(C)CC([OH2+])OC(/C(=C(/C)I)C(C)C)(C(C)C)C1=O</smiles>

11

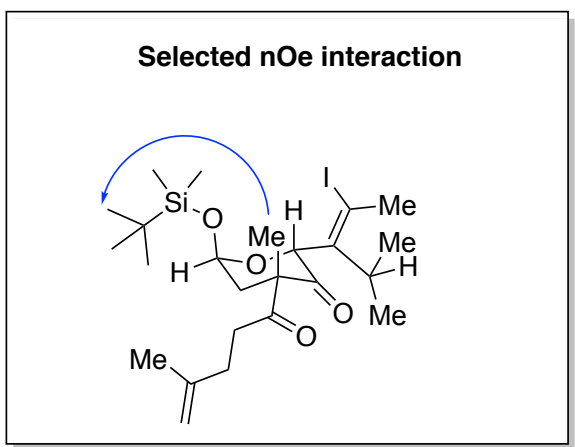

The acyl cyanide $\mathbf{1 0}$ was prepared according to a reported literature procedure. ${ }^{3}$

To a stirring solution of compound $8\left(2.2 \mathrm{~g}, 5.0 \mathrm{mmol}, 1.0\right.$ equiv.) in $12 \mathrm{~mL}$ THF at $-78{ }^{\circ} \mathrm{C}$ was added LiHMDS (1.0 M in THF, $5.5 \mathrm{~mL}, 5.5 \mathrm{mmol}, 1.1$ equiv.) dropwise over 2 minutes and the resulting solution was stirred at $-78{ }^{\circ} \mathrm{C}$ for 60 minutes, then acyl cyanide 10 ( $0.68 \mathrm{~g}, 5.5 \mathrm{mmol}, 1.1$ equiv.) was added dropwise. The reaction mixture was allowed to slowly warm to rt and stirred overnight for ca. $18 \mathrm{~h}$. The reaction was quenched by adding $10 \mathrm{~mL}$ saturated aqueous $\mathrm{NH}_{4} \mathrm{Cl}$ solution at $\mathrm{rt}$ followed by $30 \mathrm{~mL}$ ethyl acetate. The organic layer was separated and the aqueous layer was extracted with ethyl acetate $(30 \mathrm{~mL} \times 2)$. The combined organic layers were washed with brine, dried over anhydrous $\mathrm{Na}_{2} \mathrm{SO}_{4}$, filtered through a fritted glass funnel, rinsed with $10 \mathrm{~mL}$ ethyl acetate and the filtrate was concentrated in vacuo. Purification of the crude product by $\mathrm{SiO}_{2}$ flash column chromatography using $5 \%$ ethyl ether: $95 \%$ hexanes as the eluent afforded $2.5 \mathrm{~g}$ of product $\mathbf{S} 5$ as a viscous oil.

To a stirring solution of $\mathbf{S 5}\left(2.5 \mathrm{~g}, 4.7 \mathrm{mmol}, 1.0\right.$ equiv.) in $20 \mathrm{~mL}$ THF at $-78{ }^{\circ} \mathrm{C}$ was added KHMDS ( $0.5 \mathrm{M}$ in toluene, $11 \mathrm{~mL}, 5.6 \mathrm{mmol}, 1.2$ equiv.) dropwise over 10 minutes. The resulting

' The $22 \mathrm{~g}$ mixture of compounds 8 and $\mathbf{9}$ was divided into 20 equal portions and each portion was separately purified on Biotage 
solution was stirred at $-78{ }^{\circ} \mathrm{C}$ for 40 minutes, then Mel $(2.7 \mathrm{~g}, 19 \mathrm{mmol}, 4.0$ equiv.) was added dropwise. The reaction mixture was allowed to slowly warm to rt and stirred for ca. $13 \mathrm{~h}$. The reaction was quenched by adding $5 \mathrm{~mL}$ saturated aqueous $\mathrm{NH}_{4} \mathrm{Cl}$ solution at rt followed by $20 \mathrm{~mL}$ ethyl acetate. The organic layer was separated and the aqueous layer was extracted with ethyl acetate $(20 \mathrm{~mL} \times 2)$. The combined organic layers were washed with brine, dried over anhydrous $\mathrm{Na}_{2} \mathrm{SO}_{4}$, filtered through a fritted glass funnel, rinsed with $10 \mathrm{~mL}$ ethyl acetate and the filtrate was concentrated in vacuo. Purification of the crude product by $\mathrm{SiO}_{2}$ flash column chromatography on a Biotage ${ }^{\circledR}$ SNAP Ultra HP-Sphere 50 g cartridge with gradient elution (1\%-14\% ethyl acetate in hexanes with $7 \%$ DCM) afforded $1.6 \mathrm{~g}$ of compound 11 as a viscous oil (59\% over 2 steps).

Note: As seen earlier with $\mathbf{8}$, the ${ }^{1} \mathrm{H}$ NMR spectra of this compound show broadened signals which were difficult to assign and integrate properly. Several signals were difficult to find and one signal was missing from ${ }^{13} \mathrm{C} N \mathrm{NMR}$. We attribute these observations to hindered rotation of the vinyl group about the dihydro- $2 \mathrm{H}$-pyran-3(4H)-one ring.

Spectral data for 11: ${ }^{1} \mathrm{H}$ NMR $\left(600 \mathrm{MHz}, \mathrm{CDCl}_{3}\right) \delta 5.55(\mathrm{t}, \mathrm{J}=6.3 \mathrm{~Hz}, 1 \mathrm{H}), 5.38(\mathrm{Br} \mathrm{s}, 0.9 \mathrm{H})$, $4.70(\mathrm{~s}, 1 \mathrm{H}), 4.62(\mathrm{~s}, 1 \mathrm{H}), 2.85(\mathrm{dd}, J=14.6,6.3 \mathrm{~Hz}, 1 \mathrm{H}), 2.77-2.61(\mathrm{~m} .5 \mathrm{H}), 2.41(\mathrm{Br} \mathrm{s}, 0.9 \mathrm{H}), 2.31-$ $2.23(\mathrm{~m}, 1 \mathrm{H}), 2.18-2.10(\mathrm{~m}, 1 \mathrm{H}), 1.73-1.65(\mathrm{~m}, 4 \mathrm{H}), 1.36(\mathrm{~s}, 3 \mathrm{H}), 1.09(\mathrm{~d}, J=7.3 \mathrm{~Hz}, 3 \mathrm{H}), 1.00(\mathrm{~d}, J$ $=7.0 \mathrm{~Hz}, 3 \mathrm{H}), 0.90(\mathrm{~s}, 9 \mathrm{H}), 0.11(\mathrm{~s}, 3 \mathrm{H}), 0.10(\mathrm{~s}, 3 \mathrm{H}) ;{ }^{13} \mathrm{C} \mathrm{NMR}\left(150 \mathrm{MHz}, \mathrm{CDCl}_{3}\right) \delta$ 207.4, 205.3, 144.3, 142.5, 110.5, 103.6, 91.7, 85.8, 61.6, 39.1, 36.1, 32.1, 31.6, 29.8, 25.9, 22.7, 21.8, 20.8, 18.0, $-4.0,-5.3$; IR (thin film): 2956, 2930, 2884, 2857, 1707, 1461, 1362, 1254, 1120, 1081, 1048, 1000, $895,837,781 \mathrm{~cm}^{-1}$; HRMS (ESI) calculated for $\mathrm{C}_{24} \mathrm{H}_{41} \mathrm{O}_{4} \mathrm{NaSil}\left[\mathrm{M}+\mathrm{Na}^{+}\right]$571.1716; found, 571.1716.

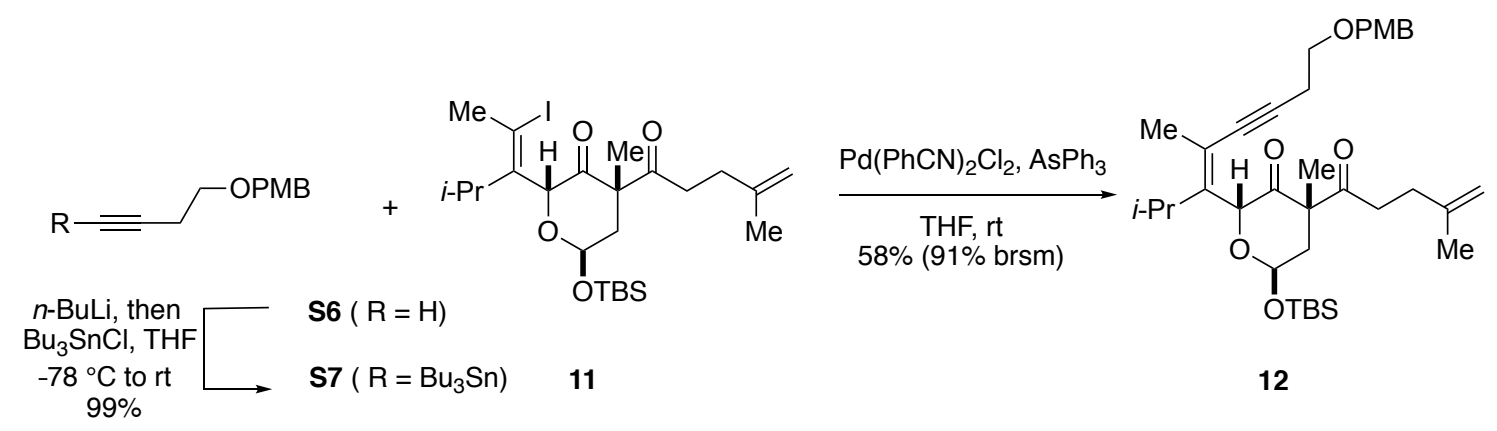

To a stirring solution of compound $\mathbf{S 6}{ }^{4}(10 \mathrm{~g}, 0.053 \mathrm{~mol}, 1.0$ equiv. $)$ in $0.10 \mathrm{~L} \mathrm{THF}$ at $-78{ }^{\circ} \mathrm{C}$ was added $n$-BuLi ( $2.57 \mathrm{M}$ in THF, $21 \mathrm{~mL}, 0.053 \mathrm{~mol}, 1.0$ equiv.) dropwise over 15 minutes and the resulting solution was stirred at $-78{ }^{\circ} \mathrm{C}$ for 60 minutes, then freshly distilled tributyltin chloride (17 g, $0.053 \mathrm{~mol}, 1.0$ equiv.) was added dropwise over 15 minutes. The reaction mixture was stirred at $-78{ }^{\circ} \mathrm{C}$ for 60 minutes, then allowed to slowly warm to rt and stirred for an additional 2 h. The reaction was quenched by adding $50 \mathrm{~mL}$ saturated aqueous $\mathrm{NH}_{4} \mathrm{Cl}$ solution at $\mathrm{rt}$ followed by $100 \mathrm{~mL}$ ethyl ether. The organic layer was separated and the aqueous layer was extracted with ethyl ether $(150 \mathrm{~mL} \times 2)$. The combined organic layers were washed with brine, dried over anhydrous $\mathrm{Na}_{2} \mathrm{SO}_{4}$, filtered through a fritted glass funnel, rinsed with $50 \mathrm{~mL}$ ethyl ether and the filtrate was concentrated in vacuo to yield $26 \mathrm{~g}$ of compound $\mathbf{S 7}$ as an oil. The crude oil was directly used for the next step without further purification. ${ }^{5}$

A stirring solution of $\mathbf{S 7}$ ( $3.4 \mathrm{~g}, 7.2 \mathrm{mmol}, 2.5$ equiv.) and compound 11 (1.6 g, $2.9 \mathrm{mmol}$. 1.0 equiv.) in $29 \mathrm{~mL}$ THF was degassed by bubbling a stream of nitrogen through it for 5 minutes. To the above solution was added $\mathrm{Pd}(\mathrm{PhCN})_{2} \mathrm{Cl}_{2}(0.11 \mathrm{~g}, 0.29 \mathrm{mmol}, 0.10$ equiv. $)$ and $\mathrm{AsPh}_{3}(0.18 \mathrm{~g}$, $0.58 \mathrm{mmol}, 0.20$ equiv.) and the resulting solution was stirred overnight at $\mathrm{rt}$ for ca. $17 \mathrm{~h}$. The solution was concentrated in vacuo. Purification of the crude product by $\mathrm{SiO}_{2}$ flash column chromatography using $10 \%$ ethyl acetate: $90 \%$ hexanes as the eluent afforded $0.6 \mathrm{~g}$ recovered 
starting material (11) and $1.0 \mathrm{~g}$ of desired product 12 as a viscous oil $(58 \%, 91 \% \mathrm{brsm}){ }^{6}$ Spectral data for 12: ${ }^{1} \mathrm{H}$ NMR $\left(500 \mathrm{MHz}, \mathrm{CDCl}_{3}\right) \delta 7.24(\mathrm{~d}, J=8.6 \mathrm{~Hz} 2 \mathrm{H}), 6.87(\mathrm{~d}, J=8.6 \mathrm{~Hz}, 2 \mathrm{H}), 5.65$ (br s, $1 \mathrm{H}), 5.55(\mathrm{t}, J=6.3 \mathrm{~Hz}, 1 \mathrm{H}), 4.70(\mathrm{~s}, 1 \mathrm{H}), 4.62(\mathrm{~s}, 1 \mathrm{H}), 4.45(\mathrm{~s}, 2 \mathrm{H}), 3.79(\mathrm{~s}, 3 \mathrm{H}), 3.52(\mathrm{td}, J=7.5,1.8$ $\mathrm{Hz}, 2 \mathrm{H}), 2.80(\mathrm{dd}, J=14.6,6.3 \mathrm{~Hz}, 1 \mathrm{H}), 2.76-2.67(\mathrm{~m}, 1 \mathrm{H}), 2.57(\mathrm{t}, J=7.4 \mathrm{~Hz}, 2 \mathrm{H}), 2.53-2.39(\mathrm{~m}$, $2 \mathrm{H}), 2.31-2.23(\mathrm{~m}, 1 \mathrm{H}), 2.18-2.11(\mathrm{~m}, 1 \mathrm{H}), 1.93(\mathrm{~s}, 3 \mathrm{H}), 1.69(\mathrm{~s}, 3 \mathrm{H}), 1.63-1.58(\mathrm{~m}, 1 \mathrm{H}), 1.30(\mathrm{~s}$, 3H), $1.07(\mathrm{~d}, J=7.3 \mathrm{~Hz}, 3 \mathrm{H}), 0.95(\mathrm{~d}, J=7.0 \mathrm{~Hz}, 3 \mathrm{H}), 0.89(\mathrm{~s}, 9 \mathrm{H}), 0.11(\mathrm{~s}, 3 \mathrm{H}), 0.08(\mathrm{~s}, 3 \mathrm{H}) ;{ }^{13} \mathrm{C} \mathrm{NMR}$ $\left(150 \mathrm{MHz}, \mathrm{CDCl}_{3}\right) \delta 208.7,205.5,159.4,144.4,143.6,130.3,129.4,120.2,113.9,110.5,91.7,89.8$, 82.6, 77.5, 72.7, 68.5, 61.6, 55.4, 39.2, 36.1, 31.6, 29.2, 25.8, 22.7, 22.2, 21.8, 21.0, 20.7, 19.9, 18.0, -4.3, -5.3; IR (thin film): 2961, 2931, 2857, 1707, 1613, 1513, 1462, 1362, 1303, 1250, 1119, $1036,1000,896,836,781 \mathrm{~cm}^{-1}$; HRMS (ESI) calculated for $\mathrm{C}_{36} \mathrm{H}_{54} \mathrm{O}_{6} \mathrm{NaSi}\left[\mathrm{M}+\mathrm{Na}^{+}\right]$633.3587; found, 633.3592 .

\section{B. Ti-mediated Oxidative Annulation en route to 18}

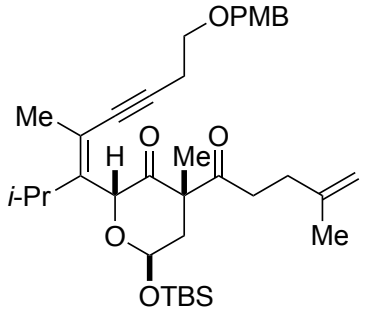

12

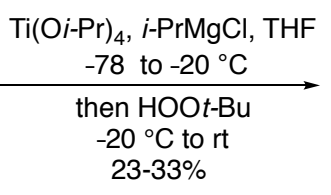

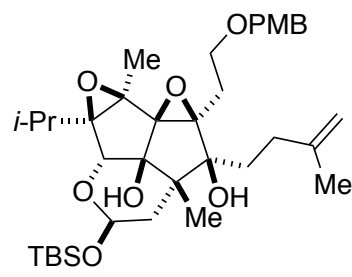

13 (6:1 with a mono-epoxide)

Note: the yield of this oxidative annulation reaction slightly varied with scale. A representative procedure is described below.

To a stirring solution of $\mathrm{Ti}(\mathrm{Oi}-\mathrm{Pr})_{4}\left(0.29 \mathrm{~g}, 1.0 \mathrm{mmol}, 2.0\right.$ equiv.) in $2.5 \mathrm{~mL} \mathrm{THF}$ at $-78{ }^{\circ} \mathrm{C}$ was added $i-\operatorname{PrMgCl}(1.63 \mathrm{M}$ in THF, $1.2 \mathrm{~mL}, 2.0 \mathrm{mmol}, 4.0$ equiv.) dropwise over 2 minutes and the resulting solution was stirred at $-78^{\circ} \mathrm{C}$ for 30 minutes. Then, a solution of compound $12(0.31$ $\mathrm{g}, 0.51 \mathrm{mmol}, 1.0$ equiv.) in $2.5 \mathrm{~mL}$ THF was added dropwise. The reaction mixture was allowed to slowly warm to $-20^{\circ} \mathrm{C}$ and stirred at $-20^{\circ} \mathrm{C}$ for ca. $4 \mathrm{~h}$. A solution of $t$-BuOOH (ca. $5.5 \mathrm{M}$ in nonane, $1.1 \mathrm{~mL}, 6.1 \mathrm{mmol}, 12$ equiv.) was then added dropwise at $-20^{\circ} \mathrm{C}$. The reaction mixture was slowly warmed to rt and stirred for ca. $12 \mathrm{~h}$, then cooled to $-78^{\circ} \mathrm{C}$ and quenched by adding $6 \mathrm{~mL}$ halfsaturated aqueous $\mathrm{NaHCO}_{3}$ solution. The mixture was allowed to warm to rt and stirred for 60 minutes. $10 \mathrm{~mL}$ ethyl ether was added, the organic layer was separated and the aqueous layer was extracted with ethyl ether $(15 \mathrm{~mL} \times 2)$. The combined organic layers were washed with brine, dried over anhydrous $\mathrm{Na}_{2} \mathrm{SO}_{4}$, filtered through a fritted glass funnel, rinsed with $15 \mathrm{~mL}$ ethyl ether and the filtrate was concentrated in vacuo. Purification of the crude product by $\mathrm{SiO}_{2}$ flash column chromatography on a Biotage ${ }^{\circledR}$ SNAP Ultra HP-Sphere 10 g cartridge with gradient elution (4\%$30 \%$ ethyl acetate in hexanes with 5\% DCM) afforded $0.12 \mathrm{~g}$ recovered starting material (12) and $77 \mathrm{mg}$ of a 6:1 mixture of desired bisepoxide (13) contaminated with a product containing a single epoxide as an oil. This mixture was further purified by HPLC to attain material suitable for spectroscopic characterization.

Spectral data for 13: ${ }^{1} \mathrm{H}$ NMR $\left(500 \mathrm{MHz}, \mathrm{CDCl}_{3}\right) \delta 7.22(\mathrm{~d}, J=8.2 \mathrm{~Hz}, 2 \mathrm{H}), 6.86(\mathrm{~d}, J=8.6$ $\mathrm{Hz}, 2 \mathrm{H}), 5.15(\mathrm{Br} \mathrm{s}, J=2.5 \mathrm{~Hz}, 1 \mathrm{H}), 4.70(\mathrm{~s}, 1 \mathrm{H}), 4.66(\mathrm{~s}, 1 \mathrm{H}), 4.45-4.41(\mathrm{~m}, 2 \mathrm{H}), 4.05(\mathrm{~s}, 1 \mathrm{H}), 3.80$ $(\mathrm{s}, 3 \mathrm{H}), 3.66-3.61(\mathrm{~m}, 2 \mathrm{H}), 3.08(\mathrm{~s}, 1 \mathrm{H}), 2.46(\mathrm{~s}, 1 \mathrm{H}), 2.39(\mathrm{dt}, J=14.6,5.9 \mathrm{~Hz}, 1 \mathrm{H}), 2.24-2.13(\mathrm{~m}$, 2H), $2.07(\mathrm{dt}, J=15.3,7.9 \mathrm{~Hz}, 1 \mathrm{H}), 1.85(\mathrm{hept}, J=6.8 \mathrm{~Hz}, 1 \mathrm{H}), 1.73(\mathrm{~s}, 3 \mathrm{H}), 1.72-1.63(\mathrm{~m}, 2 \mathrm{H}), 1.47-$ $1.42(\mathrm{~m}, 2 \mathrm{H}), 1.40(\mathrm{~s}, 3 \mathrm{H}), 1.19(\mathrm{~s}, 3 \mathrm{H}), 1.16(\mathrm{~d}, J=6.9 \mathrm{~Hz}, 3 \mathrm{H}), 1.08(\mathrm{~d}, J=7.3 \mathrm{~Hz}, 3 \mathrm{H}), 0.92(\mathrm{~s}, 9 \mathrm{H})$, 
0.15 (s, 3H), 0.12 (s, 3H); ${ }^{13} \mathrm{C}$ NMR $\left(150 \mathrm{MHz}, \mathrm{CDCl}_{3}\right) \delta 159.5,146.6,129.9,129.7,114.0,109.6$, $90.2,84.1,82.6,76.5,74.0,73.2,66.9,66.8,55.4,50.1,37.8,32.0,30.9,29.9,29.1,25.8,22.9$, 19.8, 18.2, 18.1, 17.8, 11.6, -4.3, -5.5; IR (thin film): 3512, 2954, 2930, 2853, 1254, 1156, 1097, $1038,1000,836 \mathrm{~cm}^{-1}$; MS (ESI) calculated for $\mathrm{C}_{36} \mathrm{H}_{56} \mathrm{O}_{8} \mathrm{SiNa}\left[\mathrm{M}+\mathrm{Na}^{+}\right]$667.4, found 667.1.

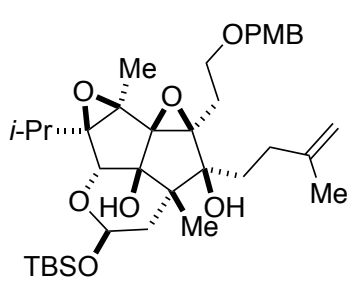

13 (6:1 with a mono-epoxide)

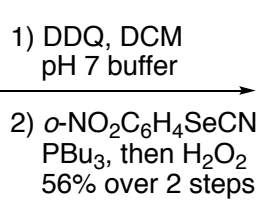

$\mathrm{PBu}_{3}$, then $\mathrm{H}_{2} \mathrm{O}_{2}$

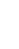

To a stirring solution of $0.13 \mathrm{~g}$ of $6: 1$ mixture of compound $13(0.11 \mathrm{~g}, 0.17 \mathrm{mmol}, 1.0$ equiv.) and it's corresponding monoepoxide $(20 \mathrm{mg}, 0.032 \mathrm{mmol})$ in $10 \mathrm{~mL}$ dichloromethane and $1.0 \mathrm{~mL}$ aqueous buffer ( $\mathrm{pH} \mathrm{7}$ ) at $0{ }^{\circ} \mathrm{C}$ was added $\mathrm{DDQ}$ ( $54 \mathrm{mg}, 0.24 \mathrm{mmol}, 1.4$ equiv.), the reaction mixture was warmed to $\mathrm{rt}$ and stirred for ca. $1 \mathrm{~h}$, then another portion of DDQ $(54 \mathrm{mg}, 0.24 \mathrm{mmol}$, 1.4 equiv.) was added at $0{ }^{\circ} \mathrm{C}$, and the reaction mixture was warmed to rt and stirred for $1 \mathrm{~h}$. The reaction was quenched by adding $6 \mathrm{~mL}$ saturated aqueous $\mathrm{NaHCO}_{3}$ solution at rt. $15 \mathrm{~mL}$ dichloromethane was added, the organic layer was separated and the aqueous layer was extracted with dichloromethane $(15 \mathrm{~mL} \times 2)$. The combined organic layers were washed with brine, dried over anhydrous $\mathrm{Na}_{2} \mathrm{SO}_{4}$, filtered through a fritted glass funnel, rinsed with $15 \mathrm{~mL}$ dichloromethane and the filtrate was concentrated in vacuo. Purification of the crude product by $\mathrm{SiO}_{2}$ flash column chromatography on a Biotage ${ }^{\circledR}$ SNAP Ultra HP-Sphere $10 \mathrm{~g}$ cartridge with gradient elution ( $8 \%-65 \%$ ethyl acetate in hexanes with $5 \%$ dichloromethane) afforded $78 \mathrm{mg}$ of a white solid.

To a stirring solution of $91 \%$ weight of the above white solid (71 $\mathrm{mg}$ ) and ortho-nitrophenyl selenocyanate ( $91 \mathrm{mg}, 0.40 \mathrm{mmol}$ ) in $9.0 \mathrm{~mL}$ THF at rt was added tributyl phosphine ( $83 \mathrm{mg}, 0.41$ $\mathrm{mmol})$ and the resulting solution was stirred at $\mathrm{rt}$ for ca. $4 \mathrm{~h}$. Sodium bicarbonate $(0.11 \mathrm{~g}, 1.3$ mmol) was added at $0{ }^{\circ} \mathrm{C}$, followed by aqueous hydrogen peroxide $(30 \%, 0.30 \mathrm{~mL})$, and the resulting mixture was warmed to $\mathrm{rt}$ and stirred for $1 \mathrm{~h}$. This process of adding hydrogen peroxide $(30 \%, 0.30 \mathrm{~mL})$ was repeated for three more times every $1 \mathrm{~h}$ for a total of four portions of hydrogen peroxide. The reaction was quenched by adding $10 \mathrm{~mL}$ water at $\mathrm{rt}$ and followed by 15 $\mathrm{mL}$ ethyl acetate. The organic layer was separated, then the aqueous layer was extracted with ethyl acetate $(15 \mathrm{~mL} \times 2)$. The combined organic layers were sequentially washed with water, saturated aqueous $\mathrm{Na}_{2} \mathrm{~S}_{2} \mathrm{O}_{3}$, brine, dried over anhydrous $\mathrm{Na}_{2} \mathrm{SO}_{4}$, filtered through a fritted glass funnel, rinsed with $10 \mathrm{~mL}$ ethyl acetate and the filtrate was concentrated in vacuo. Purification of the crude product by $\mathrm{SiO}_{2}$ flash column chromatography using $4 \%$ ethyl acetate:32\% dichloromethane:64\% hexanes as the eluent afforded $44 \mathrm{mg}$ of compound $\mathbf{1 4}$ as a white solid (56\% over 2 steps). Spectral data for 14: ${ }^{1} \mathrm{H}$ NMR $\left(500 \mathrm{MHz}, \mathrm{CDCl}_{3}\right) \delta 6.11(\mathrm{dd}, J=17.1,10.9 \mathrm{~Hz}, 1 \mathrm{H})$, $5.52(\mathrm{dd}, J=17.1,1.7 \mathrm{~Hz}, 1 \mathrm{H}), 5.39(\mathrm{dd}, J=10.9,1.7 \mathrm{~Hz}, 1 \mathrm{H}), 5.24(\mathrm{t}, J=2.4 \mathrm{~Hz}, 1 \mathrm{H}), 4.69(\mathrm{~s}, 1 \mathrm{H})$, $4.66(\mathrm{~s}, 1 \mathrm{H}), 4.09(\mathrm{~s}, 1 \mathrm{H}), 3.07(\mathrm{~s}, 1 \mathrm{H}), 2.43(\mathrm{~s}, 1 \mathrm{H}), 2.18(\mathrm{t}, J=8.3 \mathrm{~Hz}, 2 \mathrm{H}), 1.90-1.80(\mathrm{~m}, 1 \mathrm{H}), 1.75-$ $1.66(\mathrm{~m}, 4 \mathrm{H}), 1.62-1.57(\mathrm{~m}, 2 \mathrm{H}), 1.49-1.44(\mathrm{~m}, 1 \mathrm{H}), 1.23(\mathrm{~s}, 3 \mathrm{H}), 1.22(\mathrm{~s}, 3 \mathrm{H}), 1.18(\mathrm{~d}, J=6.9 \mathrm{~Hz}$, $3 \mathrm{H}), 1.10(\mathrm{~d}, J=7.2 \mathrm{~Hz}, 3 \mathrm{H}), 0.92(\mathrm{~s}, 9 \mathrm{H}), 0.15(\mathrm{~s}, 3 \mathrm{H}), 0.12(\mathrm{~s}, 3 \mathrm{H}) ;{ }^{13} \mathrm{C}$ NMR $\left(150 \mathrm{MHz}, \mathrm{CDCl}_{3}\right) \delta$ 146.8, 128.9, 119.3, 109.4, 90.1, 84.6, 84.0, 78.0, 76.6, 74.3, 74.1, 66.5, 51.0, 37.9, 31.4, 30.2, 29.9, $25.8,22.9,19.8,18.2,17.8,17.1,11.6,-4.3,-5.5$; IR (thin film): 3516, 2958, 2930, 2857, 1341, 
$1251,1145,1035,1000,927,832,780 \mathrm{~cm}^{-1}$; HRMS (ESI) calculated for $\mathrm{C}_{28} \mathrm{H}_{46} \mathrm{O}_{6} \mathrm{SiNa}\left[\mathrm{M}+\mathrm{Na}^{+}\right]$ 529.2961; found, 529.2958 .

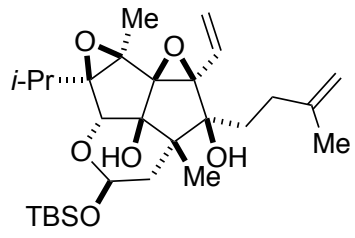

14

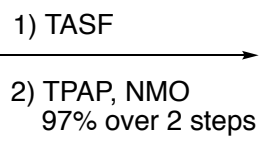

TPAP over 2 steps

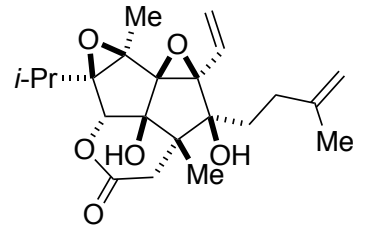

15

To a stirring solution of compound 14 ( $23 \mathrm{mg}, 0.045 \mathrm{mmol}, 1.0$ equiv.) in $2.2 \mathrm{~mL}$ DMF at $0{ }^{\circ} \mathrm{C}$ was added TASF ( $15 \mathrm{mg}, 0.054 \mathrm{mmol}, 1.2$ equiv.) and the resulting solution was stirred at $0{ }^{\circ} \mathrm{C}$ for ca. $1 \mathrm{~h}$. The reaction was quenched by adding $2 \mathrm{~mL}$ saturated aqueous $\mathrm{NH}_{4} \mathrm{Cl}$ solution at $0{ }^{\circ} \mathrm{C}$. $8 \mathrm{~mL}$ ethyl acetate was added, the organic layer was separated and the aqueous layer was extracted with ethyl acetate $(10 \mathrm{~mL} \times 2)$. The combined organic layers were washed with water $(10 \mathrm{~mL} \times 2)$, then brine, dried over anhydrous $\mathrm{Na}_{2} \mathrm{SO}_{4}$, filtered through a fritted glass funnel, rinsed with $10 \mathrm{~mL}$ ethyl acetate and the filtrate was concentrated in vacuo to yield a crude film that was directly used for the next step without further purification.

To a stirring suspension of above crude product and powdered $4 \AA$ molecular sieves (59 $\mathrm{mg}$ ) in $4.5 \mathrm{~mL} \mathrm{CH}{ }_{3} \mathrm{CN}$ at rt was added NMO (12 mg, $0.099 \mathrm{mmol}$ ) and TPAP (2.4 mg, $\left.0.007 \mathrm{mmol}\right)$. The mixture was stirred at $\mathrm{rt}$ for $2 \mathrm{~h}$, then $5.0 \mathrm{~mL}$ ethyl acetate was added. The resulting suspension was filtered through a pad of celite, rinsed with $5 \mathrm{~mL}$ ethyl acetate and the filtrate was concentrated in vacuo. Purification of the crude product by $\mathrm{SiO}_{2}$ flash column chromatography using $17 \%$ ethyl acetate:83\% hexanes as the eluent afforded $17 \mathrm{mg}$ of compound $\mathbf{1 5}$ as a white solid (97\% over 2 steps). Spectral data for $15:{ }^{1} \mathrm{H}$ NMR $\left(500 \mathrm{MHz}, \mathrm{CDCl}_{3}\right) \delta 6.10$ (dd, $J=17.0,10.9$ $\mathrm{Hz}, 1 \mathrm{H}), 5.63(\mathrm{~d}, J=16.9 \mathrm{~Hz}, 1 \mathrm{H}), 5.48(\mathrm{~d}, J=10.8 \mathrm{~Hz}, 1 \mathrm{H}), 4.72(\mathrm{~s}, 1 \mathrm{H}), 4.71(\mathrm{~s}, 1 \mathrm{H}), 4.65(\mathrm{~s}, 1 \mathrm{H})$, $3.03(\mathrm{~s}, 1 \mathrm{H}), 2.51(\mathrm{~d}, J=15.5 \mathrm{~Hz}, 1 \mathrm{H}), 2.48-2.40(\mathrm{br} \mathrm{s}, 1 \mathrm{H}), 2.22-2.12(\mathrm{~m}, 2 \mathrm{H}), 2.06(\mathrm{~d}, J=15.5 \mathrm{~Hz}$, $1 \mathrm{H}), 1.82$ (hept, $J=7.2 \mathrm{~Hz}, 1 \mathrm{H}), 1.77-1.67(\mathrm{~m}, 4 \mathrm{H}), 1.57-1.50(\mathrm{~m}, 1 \mathrm{H}), 1.27(\mathrm{~d}, J=6.9 \mathrm{~Hz}, 3 \mathrm{H}), 1.21$ (s, 3H), 1.09 (s, 3H), 1.06 (d, J = 7.4 Hz, 3H); ${ }^{13} \mathrm{C} \mathrm{NMR} \mathrm{(150} \mathrm{MHz,} \mathrm{CDCl} 3$ ) $\delta 168.4,145.7,127.8,120.8$, 110.0, 85.7, 83.3, 82.6, 79.5, 76.1, 72.0, 67.4, 56.9, 36.3, 30.6, 29.6, 29.1, 22.8, 18.4, 16.9, 12.8, 12.6; IR (thin film): 3470, 2966, 2930, 1754, 1368, 1232, 1057, 945, $734 \mathrm{~cm}^{-1}$; HRMS (ESI) calculated for $\mathrm{C}_{22} \mathrm{H}_{31} \mathrm{O}_{6}\left[\mathrm{M}+\mathrm{H}^{+}\right]$391.2121; found, 391.2111 .

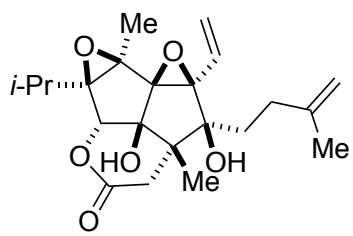

15

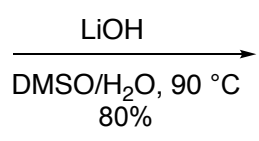

To a stirring solution of compound 15 (5.0 mg, $0.013 \mathrm{mmol}, 1.0$ equiv.) in $0.80 \mathrm{~mL}$ DMSO at $\mathrm{rt}$ was added $\mathrm{LiOH}(0.1 \mathrm{M}$ in water, $0.16 \mathrm{~mL}, 0.016 \mathrm{mmol}, 1.2$ equiv.) and the resulting mixture was stirred at $90{ }^{\circ} \mathrm{C}$ for $24 \mathrm{~h}$, then another portion of $\mathrm{LiOH}(0.1 \mathrm{M}$ in water, $0.16 \mathrm{~mL}, 0.016 \mathrm{mmol}$, 1.2 equiv.) was added and the mixture was stirred at $90{ }^{\circ} \mathrm{C}$ for another $24 \mathrm{~h}$ before being cooled to $0{ }^{\circ} \mathrm{C}$. The reaction was quenched by adding $0.1 \mathrm{~N} \mathrm{HCl}$ until a pH of 4 was reached. The mixture was diluted with $10 \mathrm{~mL}$ dichloromethane and $3 \mathrm{~mL}$ of water. The organic layer was separated and the aqueous layer was extracted with dichloromethane $(10 \mathrm{~mL} \times 2)$. The combined organic layers 
were washed with brine, dried over anhydrous $\mathrm{Na}_{2} \mathrm{SO}_{4}$, filtered through a fritted glass funnel, rinsed with $10 \mathrm{~mL}$ dichloromethane and the filtrate was concentrated in vacuo. Purification of the crude product by $\mathrm{SiO}_{2}$ flash column chromatography using $50 \%$ ethyl acetate:50\% hexanes as the eluent afforded $4.2 \mathrm{mg}$ of compound 17 as a white solid (80\%). Spectral data for $17:{ }^{1} \mathrm{H}$ NMR (600 $\left.\mathrm{MHz}, \mathrm{CDCl}_{3}\right) \delta 6.28(\mathrm{dd}, J=17.4,11.2 \mathrm{~Hz}, 1 \mathrm{H}), 5.66(\mathrm{~d}, J=17.3 \mathrm{~Hz}, 1 \mathrm{H}), 5.46(\mathrm{~d}, J=11.3 \mathrm{~Hz}, 1 \mathrm{H})$, $5.33(\mathrm{~s}, 1 \mathrm{H}), 4.71(\mathrm{~s}, 1 \mathrm{H}), 4.66(\mathrm{~s}, 1 \mathrm{H}), 3.34(\mathrm{~s}, 1 \mathrm{H}), 3.31(\mathrm{~s}, 1 \mathrm{H}), 2.98(\mathrm{~d}, J=18.8 \mathrm{~Hz}, 1 \mathrm{H}), 2.87(\mathrm{~s}$, $1 \mathrm{H}), 2.83(\mathrm{~s}, 1 \mathrm{H}), 2.46(\mathrm{~d}, J=18.8 \mathrm{~Hz}, 1 \mathrm{H}), 2.43-2.33(\mathrm{~m}, 1 \mathrm{H}), 2.23-2.16(\mathrm{~m}, 1 \mathrm{H}), 2.15-2.07(\mathrm{~m}, 1 \mathrm{H})$, $1.69(\mathrm{~s}, 3 \mathrm{H}), 1.67-1.60(\mathrm{~m}, 2 \mathrm{H}), 1.52(\mathrm{~s}, 3 \mathrm{H}), 1.18(\mathrm{~s}, 3 \mathrm{H}), 0.97(\mathrm{~d}, J=6.8 \mathrm{~Hz}, 3 \mathrm{H}), 0.93(\mathrm{~d}, J=7.0 \mathrm{~Hz}$, $3 \mathrm{H}) ;{ }^{13} \mathrm{C}$ NMR $\left(150 \mathrm{MHz}, \mathrm{CDCl}_{3}\right) \delta 168.1,146.0,130.8,119.3,110.5,92.1,90.1,87.0,86.0,80.4$, 75.1, 62.4, 49.1, 42.0, 31.3, 27.8, 24.8, 22.7, 21.4, 20.9, 18.8, 15.6; IR (thin film): 3379, 2966, 2930, $1725,1376,1261,1098,1018.961,909,734 \mathrm{~cm}^{-1}$; HRMS (ESI) calculated for $\mathrm{C}_{22} \mathrm{H}_{32} \mathrm{O}_{7} \mathrm{Na}\left[\mathrm{M}+\mathrm{Na}^{+}\right]$ 431.2046; found, 431.2039 .

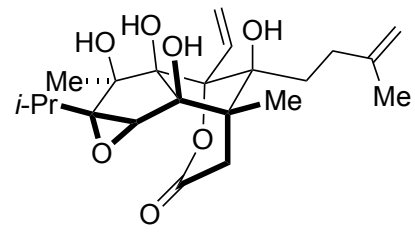

17
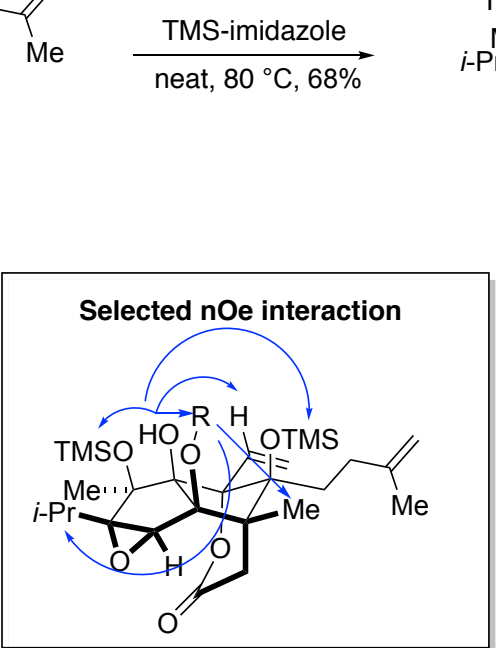

A stirring solution of compound $17(2.9 \mathrm{mg}, 7.1 \mu \mathrm{mol})$ in $0.3 \mathrm{~mL}$ TMS-imidazole was heated at $80{ }^{\circ} \mathrm{C}$ for $18 \mathrm{~h}$ before being cooled to $0{ }^{\circ} \mathrm{C}$ and adding $0.5 \mathrm{~mL}$ methanol in a dropwise fashion. The solution was warmed to rt, then stirred for 10 minutes and concentrated in vacuo. Purification of the crude product by $\mathrm{SiO}_{2}$ flash column chromatography on a Biotage ${ }^{\circledR}$ Sfär Silica HC $10 \mathrm{~g}$ cartridge with gradient elution (10 to 50\% ethyl acetate in hexanes) afforded $3.0 \mathrm{mg}$ of compound 18 as a film (68\%). Spectral data for $18:{ }^{1} \mathrm{H} \mathrm{NMR}\left(600 \mathrm{MHz}, \mathrm{CDCl}_{3}\right) \delta 6.34$ (dd, $J=17.6$, $11.3 \mathrm{~Hz}, 1 \mathrm{H}$ ), 5.54 (dd, $J=17.6,1.9 \mathrm{~Hz}, 1 \mathrm{H}), 5.43(\mathrm{dd}, J=11.3,1.9 \mathrm{~Hz}, 1 \mathrm{H}), 4.72(\mathrm{~s}, 1 \mathrm{H}), 4.59(\mathrm{~s}$, $1 \mathrm{H}), 3.48(\mathrm{~s}, 1 \mathrm{H}), 3.26(\mathrm{~s}, 1 \mathrm{H}), 2.95(\mathrm{~d}, J=18.6 \mathrm{~Hz}, 1 \mathrm{H}), 2.56$ (hept, $J=6.9 \mathrm{~Hz}, 1 \mathrm{H}), 2.41$ (d, $J=18.6$ $\mathrm{Hz}, 1 \mathrm{H}), 2.13-2.01(\mathrm{~m}, 2 \mathrm{H}), 1.72-1.59(\mathrm{~m}, 2 \mathrm{H}), 1.70(\mathrm{~s}, 3 \mathrm{H}), 1.50(\mathrm{~s}, 3 \mathrm{H}), 1.08(\mathrm{~s}, 3 \mathrm{H}), 1.00(\mathrm{~d}, J=$ $6.9 \mathrm{~Hz}, 3 \mathrm{H}), 0.83(\mathrm{~d}, J=7.0 \mathrm{~Hz}, 3 \mathrm{H}), 0.25(\mathrm{~s}, 9 \mathrm{H}), 0.18(\mathrm{~s}, 9 \mathrm{H}), 0.14(\mathrm{~s}, 9 \mathrm{H}) ;{ }^{13} \mathrm{C} \mathrm{NMR}\left(150 \mathrm{MHz}, \mathrm{CDCl}_{3}\right)$ $\delta$ 169.0, 144.6, 133.0, 118.2, 110.2, 92.9, 92.1, 90.8, 90.6, 84.3, 76.3, 61.9, 50.6, 42.2, 30.8, 28.4, 24.7, 23.41, 23.37, 19.3, 19.0, 18.6, 3.1, 2.8, 2.7; IR (thin film): 3497, 2961, 1762, 1449, 1379, 1250, 1160, 1121, 1010, 836, $752 \mathrm{~cm}^{-1}$; MS (ESI) calculated for $\mathrm{C}_{31} \mathrm{H}_{56} \mathrm{O}_{7} \mathrm{Si}_{3} \mathrm{Na}\left[\mathrm{M}+\mathrm{Na}^{+}\right]$647.3; found, 647.1. 


\section{Synthesis of Anhydroryanodol 25}

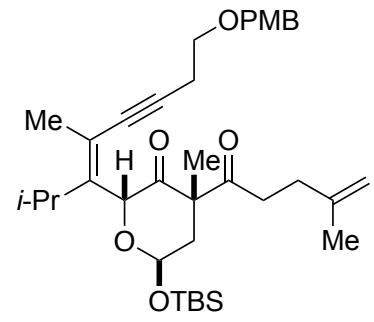

12

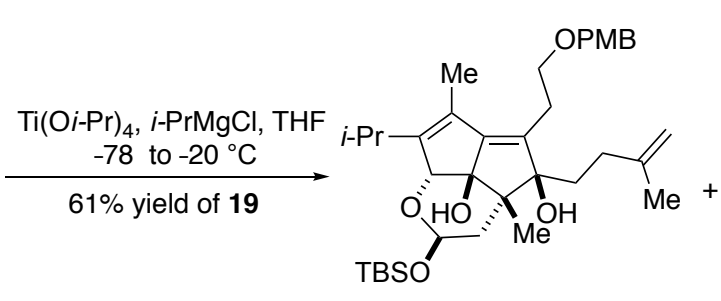

19

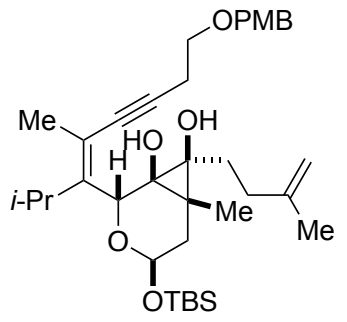

20

crude ratio of 19:20 varied from $\sim 1.4: 1$ to $1.6: 1$

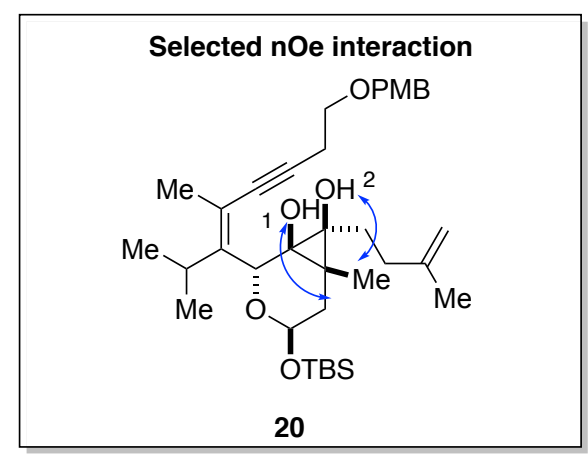

To a stirring solution of $\mathrm{Ti}(\mathrm{Oi}-\mathrm{Pr})_{4}(2.9 \mathrm{~g}, 10 \mathrm{mmol}, 2.0$ equiv. $)$ in $24 \mathrm{~mL}$ THF at $-78^{\circ} \mathrm{C}$ was added $i-\operatorname{PrMgCl}(2.2 \mathrm{M}$ in THF, $9.1 \mathrm{~mL}, 20 \mathrm{mmol}, 4.0$ equiv.) dropwise over 10 minutes and the resulting solution was stirred at $-78^{\circ} \mathrm{C}$ for 30 minutes, then a solution of compound $12(3.1 \mathrm{~g}, 5.1$ mmol, 1.0 equiv.) in $24 \mathrm{~mL} \mathrm{THF} \mathrm{was} \mathrm{added} \mathrm{dropwise} \mathrm{over} 15$ minutes. The reaction mixture was allowed to slowly warm to $-20^{\circ} \mathrm{C}$ and stirred at $-20^{\circ} \mathrm{C}$ for ca. $2 \mathrm{~h}$. The reaction was cooled to $78^{\circ} \mathrm{C}$ and quenched by adding $70 \mathrm{~mL}$ half-saturated aqueous $\mathrm{NaHCO}_{3}$ solution and the mixture was allowed to warm to rt and stirred for 60 minutes. $20 \mathrm{~mL}$ ethyl acetate was added, the organic layer was separated and the aqueous layer was extracted with ethyl acetate $(20 \mathrm{~mL} \times 2)$. The combined organic layers were washed with brine, dried over anhydrous $\mathrm{Na}_{2} \mathrm{SO}_{4}$, filtered through a fritted glass funnel, rinsed with $15 \mathrm{~mL}$ ethyl acetate and the filtrate was concentrated in vacuo. Purification of the crude product by $\mathrm{SiO}_{2}$ flash column chromatography on a Biotage ${ }^{\circledR}$ Sfär Silica $\mathrm{HC} 10 \mathrm{~g}$ cartridge with elution (4\% ethyl acetate in dichloromethane) was accomplished in three batches, and the ratio of 19:20 could only be increased to 2.6:1 (2.6 g). Additional chromatography was avoided due to the instability of 19. Based on the 2.6:1 ratio of compounds 19 and 20 ( $2.6 \mathrm{~g})$, we calculated the yield of 19 to be $61 \%$.

Spectral data for 20 (obtained as an 8:1 mixture with 19): ${ }^{1} \mathrm{H}$ NMR $\left(600 \mathrm{MHz}, \mathrm{CDCl}_{3}\right) \delta$ $7.25(\mathrm{~d}, J=8.9 \mathrm{~Hz}, 2 \mathrm{H}), 6.87(\mathrm{~d}, J=8.6 \mathrm{~Hz}, 2 \mathrm{H}), 5.70(\mathrm{~s}, 1 \mathrm{H}), 5.10(\mathrm{~d}, J=4.8 \mathrm{~Hz}, 1 \mathrm{H}), 4.71(\mathrm{~s}, 1 \mathrm{H})$, $4.70(\mathrm{~s}, 1 \mathrm{H}), 4.52(\mathrm{~d}, J=12.2 \mathrm{~Hz}, 1 \mathrm{H}), 4.49(\mathrm{~d}, J=12.2 \mathrm{~Hz}, 1 \mathrm{H}), 3.80(\mathrm{~s}, 3 \mathrm{H}), 3.56(\mathrm{t}, J=6.3 \mathrm{~Hz}, 2 \mathrm{H})$, $3.40(\mathrm{~s}, 1 \mathrm{H}), 2.89(\mathrm{~s}, 1 \mathrm{H}), 2.77$ (hept, $J=7.2 \mathrm{~Hz}, 1 \mathrm{H}), 2.57(\mathrm{t}, J=6.3 \mathrm{~Hz}, 2 \mathrm{H}), 2.49-2.42(\mathrm{~m}, 1 \mathrm{H})$, 2.04-1.96 (m, 4H), $2.00(\mathrm{~s}, 3 \mathrm{H}), 1.76(\mathrm{~s}, 3 \mathrm{H}), 1.68(\mathrm{~d}, J=15.1 \mathrm{~Hz}, 1 \mathrm{H}), 1.21(\mathrm{~d}, J=7.4 \mathrm{~Hz}, 3 \mathrm{H}), 1.13$ (d, $J=7.2 \mathrm{~Hz}, 3 \mathrm{H}), 1.10(\mathrm{~s}, 3 \mathrm{H}), 0.93(\mathrm{~s}, 9 \mathrm{H}), 0.10(\mathrm{~s}, 3 \mathrm{H}), 0.08(\mathrm{~s}, 3 \mathrm{H}) ;{ }^{13} \mathrm{C} \mathrm{NMR}\left(150 \mathrm{MHz}, \mathrm{CDCl}_{3}\right) \delta$ 159.5, 149.0, 146.6, 129.8, 129.6, 118.1, 114.0, 109.4, 90.8, 90.6, 84.5, 72.3, 69.0, 67.7, 60.9, 57.6, $55.4,38.8,36.0,33.5,29.4,26.4,25.9,23.0,21.3,21.2,20.93,20.91,20.4,15.2,-4.4,-5.5$; IR (thin film): 3411, 2930, 1709, 1611, 1513, 1462, 1250, 1121, 1035, 1001, 837, $776 \mathrm{~cm}^{-1}$; HRMS (ESI) calculated for $\mathrm{C}_{36} \mathrm{H}_{56} \mathrm{O}_{6} \mathrm{SiNa}\left[\mathrm{M}+\mathrm{Na}^{+}\right]$635.3744, found 635.3715 . 


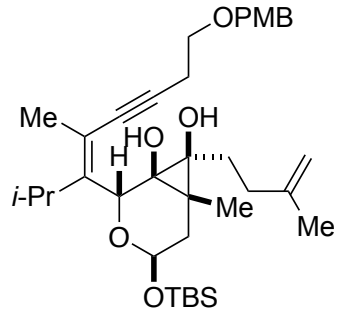

20

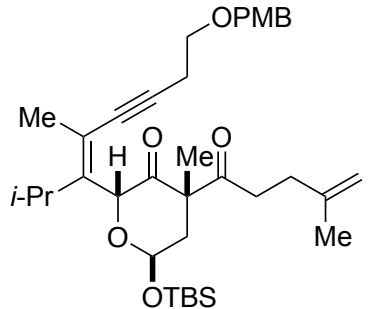

12

To a stirring solution of compound 20 (10 mg, $0.016 \mathrm{mmol}, 1.0$ equiv.) in $0.5 \mathrm{~mL}$ dichloromethane at $0{ }^{\circ} \mathrm{C}$ was added lead(IV) acetate $(14 \mathrm{mg}, 0.032 \mathrm{mmol}, 2.0$ equiv.) and the resulting solution was allowed to warm to rt and stirred for 50 minutes. The reaction was diluted with $5.0 \mathrm{~mL}$ dichloromethane and quenched with $2.0 \mathrm{~mL}$ aqueous saturated $\mathrm{NaHCO}_{3}$ solution at rt. The organic layer was separated and the aqueous layer was extracted with dichloromethane $(5.0 \mathrm{~mL} \times 2)$. The combined organic layers were washed with brine, dried over anhydrous $\mathrm{Na}_{2} \mathrm{SO}_{4}$, filtered through a fritted glass funnel, rinsed with $5.0 \mathrm{~mL}$ dichloromethane and the filtrate was concentrated in vacuo. Purification of the crude product by $\mathrm{SiO}_{2}$ flash column chromatography using $12 \%$ ethyl acetate :88\% hexanes as the eluent afforded $7.0 \mathrm{mg}$ of compound $\mathbf{1 2}$ as a white solid (70\%).<smiles>C=C(C)CCC1(O)C(CCO[18O])=C2C(C)=C(C(C)C)C(OC(C)C)C2(O)C1(C)O</smiles>

19

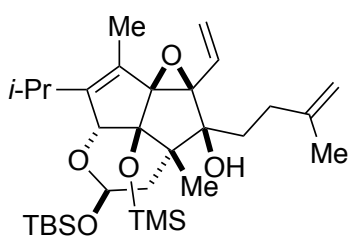

21

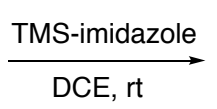

o- $\mathrm{NO}_{2} \mathrm{C}_{6} \mathrm{H}_{4} \mathrm{SeCN}$

$\frac{\mathrm{PBu}_{3} \text {, then } \mathrm{H}_{2} \mathrm{O}_{2}, \mathrm{THF}}{23 \% \text { over } 4 \text { steps }}$

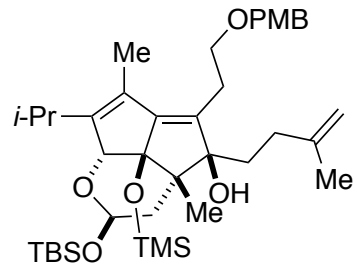

S8 toluene, $60^{\circ} \mathrm{C}$

2) $\mathrm{DDQ}, \mathrm{pH} 7$ buffer $\mathrm{DCM}, 0^{\circ} \mathrm{C}$ to rt

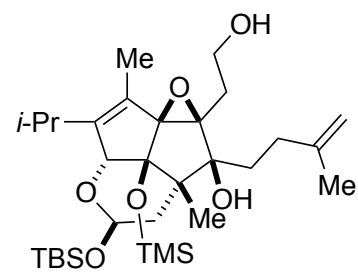

S9

To a stirring solution of $2.6 \mathrm{~g}$ of 2.6:1 mixture of compound 19 ( $1.9 \mathrm{~g}, 3.1 \mathrm{mmol}, 1.0$ equiv.) and compound 20 ( $0.70 \mathrm{~g}, 1.1 \mathrm{mmol})$ in $14 \mathrm{~mL} \mathrm{DCE}$ at rt was added TMS-imidazole $(1.1 \mathrm{~g}, 8.1 \mathrm{mmol}$, 2.6 equiv.) and the resulting solution was stirred at rt overnight for ca. $12 \mathrm{~h}$. At this time, the reaction was cooled to $0{ }^{\circ} \mathrm{C}$, quenched with $1.0 \mathrm{~mL}$ methanol, stirred at $\mathrm{rt}$ for 5 minutes, then concentrated in vacuo. Purification of the crude product by $\mathrm{SiO}_{2}$ flash column chromatography on a Biotage ${ }^{\circledR}$ Sfär Silica HC 25 g cartridge with gradient elution (3\%-24\% ethyl acetate in hexanes) afforded $2.1 \mathrm{~g}$ of compound S8 as an oil. Spectral data for S8: ${ }^{1} \mathrm{H} \mathrm{NMR}\left(600 \mathrm{MHz}, \mathrm{CDCl}_{3}\right) \delta 7.25$ (d, $J=8.6 \mathrm{~Hz}, 2 \mathrm{H}), 6.86(\mathrm{~d}, J=8.6 \mathrm{~Hz}, 2 \mathrm{H}), 5.13(\mathrm{Br} \mathrm{s}, 1 \mathrm{H}), 4.70(\mathrm{~s}, 1 \mathrm{H}), 4.69(\mathrm{~s}, 1 \mathrm{H}), 4.46(\mathrm{~s}, 2 \mathrm{H}), 4.19$ (s, $1 \mathrm{H}$ ), $3.80(\mathrm{~s}, 3 \mathrm{H}), 3.67(\mathrm{td}, J=9.0,6.3 \mathrm{~Hz}, 1 \mathrm{H}), 3.55(\mathrm{td}, J=9.0,5.8 \mathrm{~Hz}, 1 \mathrm{H}$ ), 2.77 (hept $J=7.0$ 
$\mathrm{Hz}, 1 \mathrm{H}), 2.70$ (ddd, $J=13.4,9.0,5.8 \mathrm{~Hz}, 1 \mathrm{H}), 2.49(\mathrm{~s}, 1 \mathrm{H}), 2.49-2.44(\mathrm{~m}, 1 \mathrm{H}), 2.30$ (ddd, $J=15.3$, $12.2,3.9 \mathrm{~Hz}, 1 \mathrm{H}), 2.15(\mathrm{td}, J=13.5,5.2 \mathrm{~Hz}, 1 \mathrm{H}), 1.95(\mathrm{~s}, 3 \mathrm{H}), 1.74(\mathrm{~s}, 3 \mathrm{H}), 1.71-1.58(\mathrm{~m}, 3 \mathrm{H}), 1.43-$ $1.37(\mathrm{~m}, 1 \mathrm{H}), 1.38(\mathrm{~s}, 3 \mathrm{H}), 1.16(\mathrm{~d}, J=6.9 \mathrm{~Hz}, 3 \mathrm{H}), 1.09(\mathrm{~d}, J=7.0 \mathrm{~Hz}, 3 \mathrm{H}), 0.94(\mathrm{~s}, 9 \mathrm{H}), 0.15(\mathrm{~s}, 3 \mathrm{H})$, $0.10(\mathrm{~s}, 3 \mathrm{H}), 0.02(\mathrm{~s}, 9 \mathrm{H}) ;{ }^{13} \mathrm{C}$ NMR $\left(150 \mathrm{MHz}, \mathrm{CDCl}_{3}\right) \delta 159.3,153.8,152.0,147.0,133.4,132.5$, 130.6, 129.4, 113.9, 109.4, 93.4, 91.2, 88.5, 73.9, 72.8, 70.0, 55.4, 46.1, 39.0, 32.1, 31.7, 27.6, 26.8, 25.9, 22.9, 22.8, 20.7, 19.5, 18.2, 12.8, 2.5, -4.2, -5.5 ; IR (thin film): 3466, 2955, 2926, 2860, 1512, 1459, 1249, 1096, 1016, 996, $838 \mathrm{~cm}^{-1}$; HRMS (ESI) calculated for $\mathrm{C}_{39} \mathrm{H}_{64} \mathrm{O}_{6} \mathrm{NaSi}_{2}\left[\mathrm{M}+\mathrm{Na}^{+}\right]$ 707.4139, found 707.4133 .

To a stirring solution of compound $\mathbf{S 8}(2.1 \mathrm{~g}, 3.1 \mathrm{mmol})$ in $0.10 \mathrm{~L}$ toluene at $\mathrm{rt}$ was added $\mathrm{VO}(\mathrm{Oi}-\mathrm{Pr})_{3}(0.39 \mathrm{~g}, 1.6 \mathrm{mmol}, 0.5$ equiv.) and $t-\mathrm{BuOOH}$ (ca. $5.5 \mathrm{M}$ in nonane, $1.7 \mathrm{~mL}, 9.3 \mathrm{mmol}, 3.0$ equiv). The resulting solution was stirred at $60{ }^{\circ} \mathrm{C}$ for 100 minutes. At this time, the reaction mixture was cooled to $\mathrm{rt}$ and quenched with $50 \mathrm{~mL} \mathrm{pH} 7$ buffer and $20 \mathrm{~mL}$ aqueous saturated $\mathrm{Na}_{2} \mathrm{~S}_{2} \mathrm{O}_{3}$ solution at $\mathrm{rt}$. The organic layer was separated and the aqueous layer was extracted with ethyl acetate $(60 \mathrm{~mL} \times 3)$. The combined organic layers were washed with brine, dried over anhydrous $\mathrm{Na}_{2} \mathrm{SO}_{4}$, filtered through a fritted glass funnel, rinsed with $20 \mathrm{~mL}$ ethyl acetate and the filtrate was concentrated in vacuo. Purification of the crude product by $\mathrm{SiO}_{2}$ flash column chromatography on a Biotage ${ }^{\circledR}$ Sfär Silica HC 25 g cartridge with gradient elution (4\%-34\% ethyl ether in hexanes) afforded $1.6 \mathrm{~g}$ of epoxide as an oil. ${ }^{7}$

To a stirring mixture of above epoxide $(1.6 \mathrm{~g}, 2.3 \mathrm{mmol}, 1.0$ equiv.) in $0.11 \mathrm{~L}$ dichloromethane and $36 \mathrm{~mL}$ aqueous buffer $(\mathrm{pH} 7)$ at $0{ }^{\circ} \mathrm{C}$ was added DDQ $(0.64 \mathrm{~g}, 2.8 \mathrm{mmol}, 1.2$ equiv.), the resulting mixture was warmed to $\mathrm{rt}$ and stirred for ca. $1 \mathrm{~h}$, then another portion of $\operatorname{DDQ}\left(0.64 \mathrm{~g}, 2.8 \mathrm{mmol}, 1.2\right.$ equiv.) was added at $0{ }^{\circ} \mathrm{C}$. The resulting reaction mixture was warmed to $\mathrm{rt}$ and stirred for $1 \mathrm{~h}$. The reaction was quenched by adding $80 \mathrm{~mL}$ saturated aqueous $\mathrm{NaHCO}_{3}$ solution at rt. The organic layer was separated and the aqueous layer was extracted with dichloromethane $(150 \mathrm{~mL} \times 2)$. The combined organic layers were washed with brine, dried over anhydrous $\mathrm{Na}_{2} \mathrm{SO}_{4}$, filtered through a fritted glass funnel, rinsed with $20 \mathrm{~mL}$ dichloromethane and the filtrate was concentrated in vacuo. Purification of the crude product by $\mathrm{SiO}_{2}$ flash column chromatography on a Biotage ${ }^{\circledR}$ Sfär Silica HC 25 g cartridge with gradient elution (5\%-40\% ethyl acetate in hexanes) afforded $0.76 \mathrm{~g}$ of compound $\mathbf{S 9}$ as an oil.

To a stirring solution of $\mathbf{S 9}(0.76 \mathrm{~g}, 1.3 \mathrm{mmol}, 1.0$ equiv.) and ortho-nitrophenyl selenocyanate $(0.59 \mathrm{~g}, 2.6 \mathrm{mmol}, 2.0$ equiv. $)$ in $50 \mathrm{~mL}$ THF at rt was added tributyl phosphine $(0.53$ g, $2.6 \mathrm{mmol}, 2.0$ equiv.) and the resulting mixture was stirred at $\mathrm{rt}$ for ca. $4 \mathrm{~h}$. Sodium bicarbonate $\left(0.70 \mathrm{~g}, 8.4 \mathrm{mmol}, 6.5\right.$ equiv.) was added at $0{ }^{\circ} \mathrm{C}$, followed by adding aqueous hydrogen peroxide $(30 \%, 5.8 \mathrm{~mL})$, the mixture was warmed to $\mathrm{rt}$ and stirred for $1 \mathrm{~h}$. This process of adding hydrogen peroxide $(30 \%, 5.8 \mathrm{~mL})$ was repeated for three more times every $1 \mathrm{~h}$ for a total of four portions of hydrogen peroxide. The reaction was quenched by adding $100 \mathrm{~mL}$ water at rt, then $100 \mathrm{~mL}$ ethyl acetate was added, the organic layer was separated and the aqueous layer was extracted with ethyl acetate $(120 \mathrm{~mL} \times 3)$. The combined organic layers were sequentially washed with water, saturated aqueous $\mathrm{Na}_{2} \mathrm{~S}_{2} \mathrm{O}_{3}$ and brine, dried over anhydrous $\mathrm{Na}_{2} \mathrm{SO}_{4}$, filtered through a fritted glass funnel, rinsed with $10 \mathrm{~mL}$ ethyl acetate and the filtrate was concentrated in vacuo. Purification of the crude product by $\mathrm{SiO}_{2}$ flash column chromatography using $7 \%$ ethyl acetate: 93\% hexanes as the eluent afforded $0.39 \mathrm{~g}$ of compound $\mathbf{2 1}$ as a white solid (23\% over 4 steps). Spectral data for $21:{ }^{1} \mathrm{H} \mathrm{NMR}\left(600 \mathrm{MHz}, \mathrm{CDCl}_{3}\right) \delta 6.08$ (dd, $\left.J=17.1,10.9 \mathrm{~Hz}, 1 \mathrm{H}\right), 5.53(\mathrm{dd}, J=17.1$, $1.9 \mathrm{~Hz}, 1 \mathrm{H}), 5.27(\mathrm{dd}, J=10.9,1.9 \mathrm{~Hz}, 1 \mathrm{H}), 5.18(\mathrm{~d}, J=4.8 \mathrm{~Hz}, 1 \mathrm{H}), 4.68(\mathrm{~s}, 1 \mathrm{H}), 4.66(\mathrm{~s}, 1 \mathrm{H}), 4.56$ $(\mathrm{d}, J=1.6 \mathrm{~Hz}, 1 \mathrm{H}$ ), $3.28(\mathrm{~s}, 1 \mathrm{H}), 2.75$ (hept, $J=7.3 \mathrm{~Hz}, 1 \mathrm{H}), 2.24-2.10(\mathrm{~m}, 2 \mathrm{H}), 1.72(\mathrm{~s}, 3 \mathrm{H}), 1.72-$ $1.66(\mathrm{~m}, 1 \mathrm{H}), 1.59(\mathrm{~d}, J=15.1 \mathrm{~Hz}, 1 \mathrm{H}), 1.56-1.51(\mathrm{~m}, 1 \mathrm{H}), 1.50(\mathrm{~d}, J=1.6 \mathrm{~Hz}, 3 \mathrm{H}), 1.46(\mathrm{dd}, J=14.5$, $5.5 \mathrm{~Hz}, 1 \mathrm{H}), 1.17(\mathrm{~s}, 3 \mathrm{H}), 1.16(\mathrm{~d}, J=6.9 \mathrm{~Hz}, 3 \mathrm{H}), 1.10(\mathrm{~d}, J=7.1 \mathrm{~Hz}, 3 \mathrm{H}), 0.90(\mathrm{~s}, 9 \mathrm{H}), 0.13(\mathrm{~s}, 9 \mathrm{H})$, $0.12(\mathrm{~s}, 3 \mathrm{H}), 0.08(\mathrm{~s}, 3 \mathrm{H}) ;{ }^{13} \mathrm{C} \mathrm{NMR}\left(150 \mathrm{MHz}, \mathrm{CDCl}_{3}\right) \delta 149.1,146.9,131.6,130.8,118.3,109.4$, 
90.6, 85.9, 84.8, 81.5, 80.6, 76.2, 53.9, 36.5, 31.1, 29.6, 27.5, 25.9, 22.9, 21.8, 19.8, 18.0, 14.9, 11.0, 2.0, -3.8, -5.2 ; IR (thin film): 3535, 2959, 2930, 2853, 1462, 1388, 1252, 1148, 1096, 1026, 933, 877, 840, $779 \mathrm{~cm}^{-1}$; HRMS (ESI) calculated for $\mathrm{C}_{31} \mathrm{H}_{54} \mathrm{O}_{5} \mathrm{Si}_{2} \mathrm{Na}\left[\mathrm{M}+\mathrm{Na}^{+}\right]$585.3407, found 585.3411.

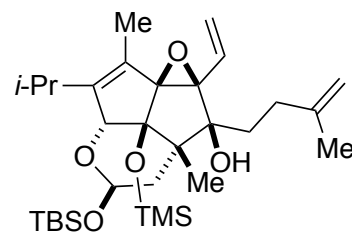

21

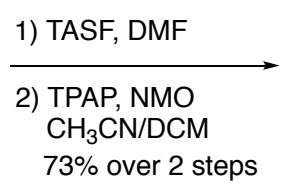

$73 \%$ over 2 steps

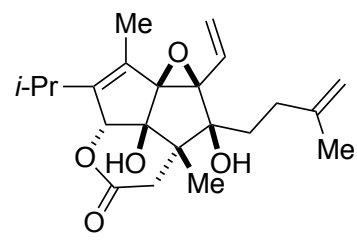

S10

To a stirring solution of 21 ( $0.39 \mathrm{~g}, 0.69 \mathrm{mmol}, 1.0$ equiv.) in $45 \mathrm{~mL} \mathrm{DMF}$ at $0{ }^{\circ} \mathrm{C}$ was added TASF ( $0.96 \mathrm{~g}, 3.5 \mathrm{mmol}, 5.0$ equiv.). The solution was warmed to $\mathrm{rt}$ and stirred for ca. $5 \mathrm{~h}$. The reaction was quenched by adding $60 \mathrm{~mL} \mathrm{pH} 7$ buffer at $0{ }^{\circ} \mathrm{C} .100 \mathrm{~mL}$ ethyl acetate was added, the organic layer was separated and the aqueous layer was extracted with ethyl acetate $(200 \mathrm{~mL} \times 3)$. The combined organic layers were washed with water $(100 \mathrm{~mL} \times 2)$, then brine, dried over anhydrous $\mathrm{Na}_{2} \mathrm{SO}_{4}$, filtered through a fritted glass funnel, rinsed with $30 \mathrm{~mL}$ ethyl acetate and the filtrate was concentrated in vacuo to yield a crude oil. The crude oil was directly used for the next step without further purification.

To a stirring suspension of above crude oil and powdered $4 \AA$ molecular sieves $(1.1 \mathrm{~g})$ in $30 \mathrm{~mL}$ of $\mathrm{CH}_{3} \mathrm{CN} /$ dichloromethane $(\mathrm{v} / \mathrm{v}, 2: 1)$ at $\mathrm{rt}$ was added NMO $(0.36 \mathrm{~g}, 3.1 \mathrm{mmol})$ and TPAP ( $32 \mathrm{mg}, 0.091 \mathrm{mmol})$. The mixture was stirred at $\mathrm{rt}$ for $2 \mathrm{~h}$, then TPAP $(20 \mathrm{mg}, 0.057 \mathrm{mmol}$ ) was added. The mixture was stirred at $\mathrm{rt}$ for another $1 \mathrm{~h}$ and $5.0 \mathrm{~mL}$ ethyl acetate was added. The suspension was filtered through a pad of celite, rinsed with $5 \mathrm{~mL}$ ethyl acetate and the filtrate was concentrated in vacuo. Purification of the crude product by $\mathrm{SiO}_{2}$ flash column chromatography using $20 \%$ ethyl acetate: $80 \%$ hexanes as the eluent afforded $0.19 \mathrm{~g}$ of compound $\mathbf{S 1 0}$ as a white solid (73\% over 2 steps). Spectral data for S10: ${ }^{1} \mathrm{H}$ NMR $\left(500 \mathrm{MHz}, \mathrm{CDCl}_{3}\right) \delta 6.08$ (dd, $J=17.0,10.9$ $\mathrm{Hz}, 1 \mathrm{H}), 5.61(\mathrm{dd}, J=17.1,1.6 \mathrm{~Hz}, 1 \mathrm{H}), 5.41(\mathrm{dd}, J=10.9,1.6 \mathrm{~Hz}, 1 \mathrm{H}), 5.13(\mathrm{~d}, J=1.8 \mathrm{~Hz}, 1 \mathrm{H}), 4.73$ $(\mathrm{s}, 1 \mathrm{H}), 4.67(\mathrm{~s}, 1 \mathrm{H}), 2.88-2.78(\mathrm{~m}, 1 \mathrm{H}), 2.84(\mathrm{~s}, 1 \mathrm{H}), 2.50(\mathrm{~s}, 1 \mathrm{H}), 2.43(\mathrm{~d}, J=15.3 \mathrm{~Hz}, 1 \mathrm{H}), 2.21-$ $2.08(\mathrm{~m}, 2 \mathrm{H}), 2.05(\mathrm{~d}, J=15.3 \mathrm{~Hz}, 1 \mathrm{H}), 1.77-1.68(\mathrm{~m}, 1 \mathrm{H}), 1.72(\mathrm{~s}, 3 \mathrm{H}), 1.57(\mathrm{~d}, J=1.8 \mathrm{~Hz}, 3 \mathrm{H}), 1.57-$ $1.50(\mathrm{~m}, 1 \mathrm{H}), 1.19(\mathrm{~d}, J=6.9 \mathrm{~Hz}, 3 \mathrm{H}), 1.12(\mathrm{~s}, 3 \mathrm{H}), 1.06(\mathrm{~d}, J=7.2 \mathrm{~Hz}, 3 \mathrm{H}) ;{ }^{13} \mathrm{C} \mathrm{NMR}\left(150 \mathrm{MHz}, \mathrm{CDCl}_{3}\right)$ $\delta 169.7,148.9,145.5,132.0,129.0,120.0,110.3,87.5,87.1,83.9,77.0,75.1,55.8,36.3,30.8$, 29.9, 27.6, 22.7, 22.2, 19.2, 12.9, 11.0; IR (thin film): 3460, 2936, 2930, 2870, 1748, 1456, 1369, $1247,1125,1038,1021,927,884 \mathrm{~cm}^{-1}$; HRMS (ESI) calculated for $\mathrm{C}_{22} \mathrm{H}_{31} \mathrm{O}_{5}\left[\mathrm{M}+\mathrm{H}^{+}\right] 375.2171$, found 375.2161 .

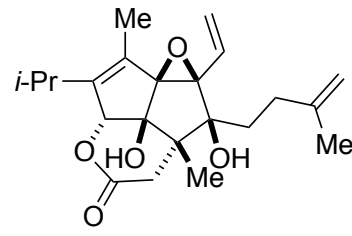

S10

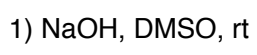

2) Hoveyda-Grubbs II toluene, $85^{\circ} \mathrm{C}$ $92 \%$ over 2 steps 22:23 = 1.3:1

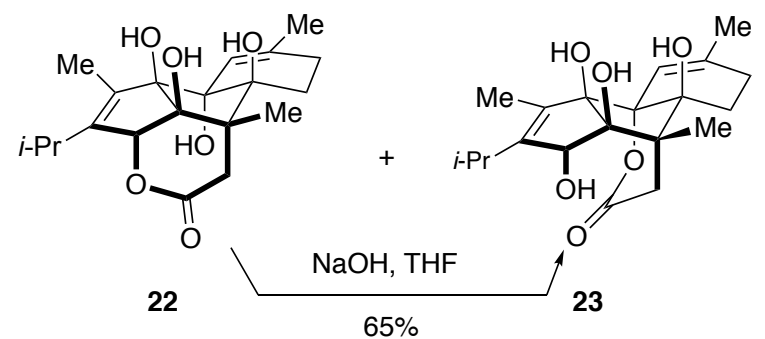




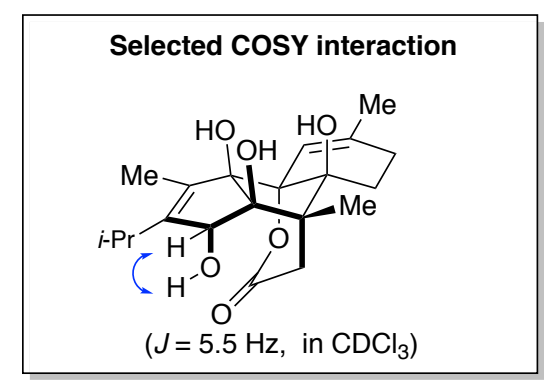

To a stirring solution of compound $\mathbf{S} 10$ ( $0.17 \mathrm{~g}, 0.45 \mathrm{mmol}, 1.0$ equiv.) in $9.0 \mathrm{~mL}$ DMSO at $5{ }^{\circ} \mathrm{C}$ was added $\mathrm{NaOH}(0.5 \mathrm{M}$ in water, $5.4 \mathrm{~mL}, 2.7 \mathrm{mmol}, 6.0$ equiv.) and the resulting mixture was stirred at $\mathrm{rt}$ for $48 \mathrm{~h}$. The reaction mixture was cooled to $6^{\circ} \mathrm{C}$ and quenched by adding $0.1 \mathrm{~N} \mathrm{HCl}$ until a pH of 3 was reached. $20 \mathrm{~mL}$ dichloromethane was added and the mixture was stirred at $\mathrm{rt}$ for 1 minute. The organic layer was separated and the aqueous layer was extracted with dichloromethane $(80 \mathrm{~mL} \times 3)$. The combined organic layers were washed with brine, dried over anhydrous $\mathrm{Na}_{2} \mathrm{SO}_{4}$, filtered through a fritted glass funnel, rinsed with $10 \mathrm{~mL}$ dichloromethane and the filtrate was concentrated in vacuo to yield a crude film. The crude film was used directly for the next step without further purification.

To a mixture of the above crude film and Hoveyda-Grubbs (II) catalyst ( $28 \mathrm{mg}, 0.045 \mathrm{mmol}$ ) was added $90 \mathrm{~mL}$ toluene, the reaction solution was heated at $85^{\circ} \mathrm{C}$ for $18 \mathrm{~h}$, then cooled down to $\mathrm{rt}$ and concentrated in vacuo. Purification of the crude product by $\mathrm{SiO}_{2}$ flash column chromatography using gradient elution (3-5\% methanol in chloroform) afforded $94 \mathrm{mg}$ of compound 22 as a white solid and $57 \mathrm{mg}$ of compound $\mathbf{2 3}$ as a white solid (92\% over 2 steps for compound 22 and 23, 1.3: 1 ratio was assigned by ${ }^{1} \mathrm{H}$ NMR of the crude product mixture before column chromatography). Spectral data for $23:{ }^{1} \mathrm{H}$ NMR $\left(600 \mathrm{MHz}, \mathrm{CD}_{3} \mathrm{OD}\right) \delta 5.78(\mathrm{~s}, 1 \mathrm{H}), 4.75(\mathrm{~s}$, $1 \mathrm{H}), 3.77(\mathrm{~d}, J=19.8 \mathrm{~Hz}, 1 \mathrm{H}), 2.71$ (hept, $J=7.2 \mathrm{~Hz}, 1 \mathrm{H}), 2.36-2.28(\mathrm{~m}, 2 \mathrm{H}), 2.18(\mathrm{dd}, J=18.8,7.7$ $\mathrm{Hz}, 1 \mathrm{H}), 1.87-1.80(\mathrm{~m}, 1 \mathrm{H}), 1.79(\mathrm{~s}, 3 \mathrm{H}), 1.72-1.67(\mathrm{~m}, 4 \mathrm{H}), 1.23(\mathrm{~s}, 3 \mathrm{H}), 1.15(\mathrm{~d}, J=6.9 \mathrm{~Hz}, 3 \mathrm{H})$, $1.10(\mathrm{~d}, J=7.1 \mathrm{~Hz}, 3 \mathrm{H}) ;{ }^{13} \mathrm{C} \mathrm{NMR}\left(150 \mathrm{MHz}, \mathrm{CD}_{3} \mathrm{OD}\right) \delta 173.3,147.5,144.2,133.8,119.0,92.3,90.5$, $89.2,84.3,81.9,48.9,39.8,28.24,28.16,23.6,23.5,21.6,19.5,15.2,11.6$; IR (thin film): 3443 , $3341,2964,2938,2872,1713,1370,1263,1221,1147,1129,1081,1001,968 \mathrm{~cm}^{-1}$; HRMS (ESI) calculated for $\mathrm{C}_{20} \mathrm{H}_{27} \mathrm{O}_{6}\left[\mathrm{M}-\mathrm{H}^{+}\right]$363.1808; found, 363.1799 .

Conversion of compound $\mathbf{2 2}$ to $\mathbf{2 3}$ :

To a stirring solution of compound $22(82 \mathrm{mg}, 0.22 \mathrm{mmol}, 1.0$ equiv.) in $1.6 \mathrm{~mL}$ THF at rt was added aqueous $\mathrm{NaOH}(1.0 \mathrm{M}$ in water, $0.35 \mathrm{~mL}, 0.35 \mathrm{mmol}, 1.6$ equiv.) and the resulting mixture was stirred at $\mathrm{rt}$ for 40 minutes before it was cooled to $0{ }^{\circ} \mathrm{C}$. Aqueous acetic acid $(1.0 \mathrm{M}$ in water, $0.35 \mathrm{~mL}, 0.35 \mathrm{mmol}, 1.6$ equiv.) was then added dropwise. Sodium chloride was added to saturate the aqueous phase. $10 \mathrm{~mL}$ dichloromethane was added and the mixture was warmed to $\mathrm{rt}$ and stirred for 1 minute, the organic layer was separated and the aqueous layer was extracted with dichloromethane $(10 \mathrm{~mL} \times 4)$. The combined organic layers were washed with brine, dried over anhydrous $\mathrm{Na}_{2} \mathrm{SO}_{4}$, filtered through a fritted glass funnel, rinsed with $10 \mathrm{~mL}$ dichloromethane and the filtrate was concentrated in vacuo. Purification of the crude product by $\mathrm{SiO}_{2}$ flash column chromatography using gradient elution (3-5\% methanol in chloroform) afforded $53 \mathrm{mg}$ of compound $\mathbf{2 3}$ as a white solid (65\%). 


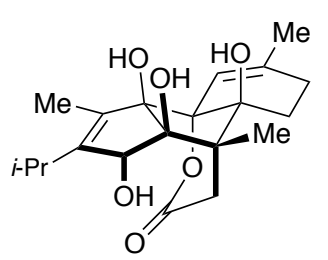

23
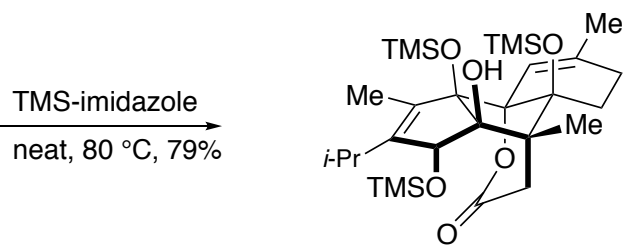

24

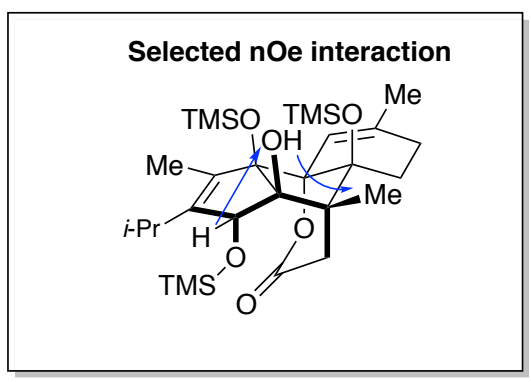

A stirring solution of compound 23 ( $0.12 \mathrm{~g}, 0.33 \mathrm{mmol}, 1.0$ equiv.) in $17 \mathrm{~mL}$ TMS-imidazole was heated at $80^{\circ} \mathrm{C}$ for $18 \mathrm{~h}$ before it was cooled to $0^{\circ} \mathrm{C}$. The reaction was quenched by adding 8 $\mathrm{mL}$ methanol dropwise, and the solution was warmed to $\mathrm{rt}$, then stirred for 10 minutes and concentrated in vacuo to yield a crude solid. Purification of the crude solid by $\mathrm{SiO}_{2}$ flash column chromatography using gradient elution (4-14\% ethyl acetate in hexanes) afforded $0.15 \mathrm{~g}$ of compound 24 as a white solid (79\%). Spectral data for $24:{ }^{1} \mathrm{H} \mathrm{NMR}\left(600 \mathrm{MHz}, \mathrm{CDCl}_{3}\right) \delta 5.74(\mathrm{~s}$, $1 \mathrm{H}), 4.68(\mathrm{~d}, J=2.4 \mathrm{~Hz}, 1 \mathrm{H}$ ), $3.67(\mathrm{~d}, J=19.8 \mathrm{~Hz}, 1 \mathrm{H}$ ), $3.37(\mathrm{~s}, 1 \mathrm{H}), 2.52$ (hept, $J=7.2 \mathrm{~Hz}, 1 \mathrm{H}$ ), 2.27$2.20(\mathrm{~m}, 1 \mathrm{H}), 2.20(\mathrm{~d}, J=19.7 \mathrm{~Hz}, 1 \mathrm{H}), 2.11(\mathrm{dt}, J=18.5,8.1 \mathrm{~Hz}, 1 \mathrm{H}), 1.86(\mathrm{dt}, J=14.7,8.7 \mathrm{~Hz}, 1 \mathrm{H})$, $1.75(\mathrm{~s}, 3 \mathrm{H}), 1.72(\mathrm{~d}, J=2.4 \mathrm{~Hz}, 3 \mathrm{H}), 1.72-1.68(\mathrm{~m}, 1 \mathrm{H}), 1.13-1.08(\mathrm{~m}, 9 \mathrm{H}), 0.20(\mathrm{~s}, 9 \mathrm{H}), 0.17(\mathrm{~s}, 9 \mathrm{H})$, 0.10 (s, 9H); ${ }^{13} \mathrm{C}$ NMR $\left(150 \mathrm{MHz}, \mathrm{CDCl}_{3}\right) \delta 170.3,146.1,139.6,133.0,120.7,94.8,88.6,88.3,86.3$, 85.0, 48.8, 39.5, 27.5, 25.9, 23.5, 21.8, 20.1, 19.9, 16.6, 13.2, 2.2, 2.1, 0.8; IR (thin film): 3529, 2961, 2919, 2850, 1745, 1247, 1156, 1115, 1027, 1000, 902. 864, $838 \mathrm{~cm}^{-1}$; HRMS (ESI) calculated for $\mathrm{C}_{29} \mathrm{H}_{52} \mathrm{O}_{6} \mathrm{Si}_{3} \mathrm{Na}\left[\mathrm{M}+\mathrm{Na}^{+}\right]$603.2969; found, 603.2964.

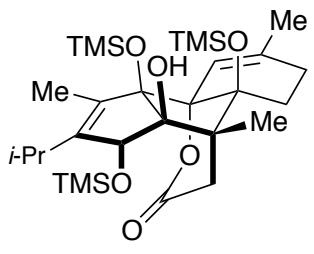

24

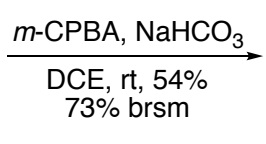

DCE, rt, $54 \%$
$73 \%$ brsm

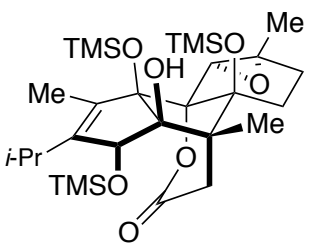

S11

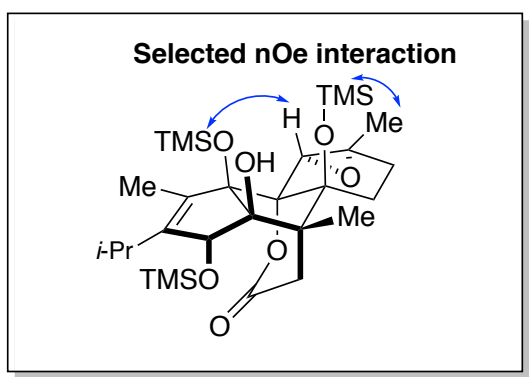

A stirring solution of compound $24\left(10 \mathrm{mg}, 0.017 \mathrm{mmol}, 1.0\right.$ equiv.) in $0.17 \mathrm{~mL} \mathrm{DCE}$ at $0{ }^{\circ} \mathrm{C}$ was sequentially added $\mathrm{NaHCO}_{3}(7.1 \mathrm{mg}, 0.085 \mathrm{mmol}, 5.0$ equiv.) and $m$-CPBA (ca. $77 \%$ pure, 7.6 $\mathrm{mg}, 0.034 \mathrm{mmol}, 2.0$ equiv.). The mixture was warmed to $\mathrm{rt}$ and stirred for $48 \mathrm{~h}$ before it was 
cooled to $0{ }^{\circ} \mathrm{C}$. The mixture was diluted with $5 \mathrm{~mL}$ dichloromethane, $4 \mathrm{~mL}$ saturated aqueous sodium bicarbonate and $4 \mathrm{~mL}$ saturated aqueous sodium thiosulfate were sequentially added dropwise, then the mixture was warmed to rt and stirred for 10 minutes. The organic layer was separated and the aqueous layer was extracted with dichloromethane $(10 \mathrm{~mL} \times 3)$. The combined organic layers were washed with brine, dried over anhydrous $\mathrm{Na}_{2} \mathrm{SO}_{4}$, filtered through a fritted glass funnel, rinsed with $5 \mathrm{~mL}$ dichloromethane and the filtrate was concentrated in vacuo to yield a crude solid. Purification of the crude product by $\mathrm{SiO}_{2}$ flash column chromatography using gradient elution (14-25\% ethyl acetate in hexanes) afforded $2.8 \mathrm{mg}$ recovered starting material (24) and $5.4 \mathrm{mg}$ of compound $\mathbf{S 1 1}$ as a white solid (54\%, 73\% brsm). Spectral data for S11: ${ }^{1} \mathrm{H}$ NMR $\left(600 \mathrm{MHz}, \mathrm{CDCl}_{3}\right) \delta 4.68(\mathrm{~d}, J=2.5 \mathrm{~Hz}, 1 \mathrm{H}), 3.66(\mathrm{~d}, J=19.6 \mathrm{~Hz}, 1 \mathrm{H}), 3.38(\mathrm{~s}, 1 \mathrm{H}), 3.02(\mathrm{~s}, 1 \mathrm{H}), 2.51$ (hept, $J=7.1 \mathrm{~Hz}, 1 \mathrm{H}), 2.16-2.11(\mathrm{~m}, 1 \mathrm{H}), 2.09(\mathrm{~d}, J=19.6 \mathrm{~Hz}, 1 \mathrm{H}), 1.89-1.82(\mathrm{~m}, 1 \mathrm{H}), 1.80(\mathrm{~d}, J=$ $2.1 \mathrm{~Hz}, 3 \mathrm{H}), 1.50-1.44(\mathrm{~m}, 2 \mathrm{H}), 1.42(\mathrm{~s}, 3 \mathrm{H}), 1.14(\mathrm{~s}, 3 \mathrm{H}), 1.12-1.08(\mathrm{~m}, 6 \mathrm{H}), 0.30(\mathrm{~s}, 9 \mathrm{H}), 0.20(\mathrm{~s}$, 9H), 0.13 (s, 9H); ${ }^{13} \mathrm{C} \mathrm{NMR}\left(150 \mathrm{MHz}, \mathrm{CDCl}_{3}\right) \delta 168.8,146.4,132.8,95.6,87.7,86.5,85.3,84.7,57.2$, $56.6,49.0,38.3,26.3,25.9,23.7,20.1,19.9,19.6,17.3,13.3,3.3,2.0,0.8$; IR (thin film): 3550 , 2957, 2930, 2874, 1751, 1452, 1410, 1376, 1250, 1166, 1089, 1035, 968, 898, 861, 841, $752 \mathrm{~cm}^{-1}$; HRMS (ESI) calculated for $\mathrm{C}_{29} \mathrm{H}_{52} \mathrm{O}_{7} \mathrm{Si}_{3} \mathrm{Na}\left[\mathrm{M}+\mathrm{Na}^{+}\right]$619.2919; found, 619.2924.

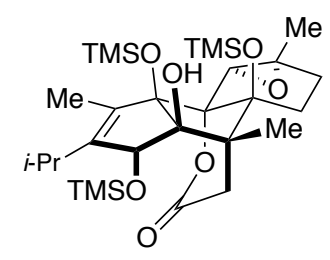

S11

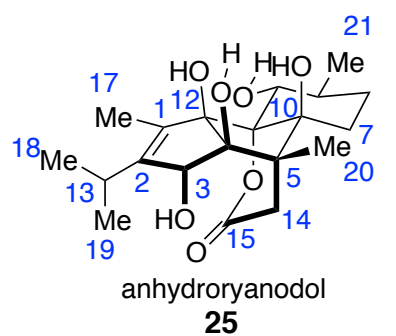

25

To a mixture of $\mathrm{Cp}_{2} \mathrm{TiCl}_{2}(13 \mathrm{mg}, 0.052 \mathrm{mmol})$ and activated zinc powder $(7.0 \mathrm{mg}, 0.11$ $\mathrm{mmol}$ ) was added $2.6 \mathrm{~mL} \mathrm{THF}$, and the mixture was stirred at $\mathrm{rt}$ for $1 \mathrm{~h}$ to provide a green mixture. To a stirring neat solution of compound $\mathbf{S 1 1}\left(6.1 \mathrm{mg}, 0.010 \mathrm{mmol}, 1.0\right.$ equiv.) and $\mathrm{Et}_{3} \mathrm{SiH}$ ( $23 \mathrm{mg}$, $0.20 \mathrm{mmol}, 20$ equiv.) at $0^{\circ} \mathrm{C}$ was added the freshly prepared $\mathrm{Cp}_{2} \mathrm{TiCl}$ (ca. $0.02 \mathrm{~N}$ in THF, $1.4 \mathrm{~mL}$, $0.028 \mathrm{mmol}, 2.8$ equiv.). The reaction mixture was warmed to $\mathrm{rt}$ and stirred for ca. $20 \mathrm{~h}$ before additional freshly prepared $\mathrm{Cp}_{2} \mathrm{TiCl}$ (ca. $0.10 \mathrm{~N}$ in THF, $0.28 \mathrm{~mL}, 0.028 \mathrm{mmol}, 2.8$ equiv.) was added. The reaction mixture was heated at $50{ }^{\circ} \mathrm{C}$ for $2 \mathrm{~h}$, then additional $\mathrm{Cp}_{2} \mathrm{TiCl}$ reagent (ca. $0.10 \mathrm{~N}$ in THF, $0.28 \mathrm{~mL}, 0.028 \mathrm{mmol}, 2.8$ equiv.) was added, the reaction mixture was heated at $50{ }^{\circ} \mathrm{C}$ for another $2 \mathrm{~h}$, then cooled to $0{ }^{\circ} \mathrm{C}$ and quenched by adding $3 \mathrm{~mL}$ saturated aqueous $\mathrm{NaH}_{2} \mathrm{PO}_{4} .5 \mathrm{~mL}$ ethyl ether was added, the organic layer was separated and the aqueous layer was extracted with ethyl ether $(10 \mathrm{~mL} \times 3)$. The combined organic layers were washed with brine, dried over anhydrous $\mathrm{Na}_{2} \mathrm{SO}_{4}$, filtered through a fritted glass funnel, rinsed with $5 \mathrm{~mL}$ ethyl ether and the filtrate was concentrated in vacuo to yield a crude white solid. The crude product was dissolved in $0.5 \mathrm{~mL}$ dichloromethane, filtered through a short silica gel plug and washed with $14 \%$ ethyl acetate: $86 \%$ hexanes as the eluent to yield a crude white solid. ${ }^{8}$

To a stirring solution of the above crude material in $0.20 \mathrm{~mL} \mathrm{DMF}$ at $0{ }^{\circ} \mathrm{C}$ was added a solution of TASF (14 mg, $0.051 \mathrm{mmol}$ ) in $0.20 \mathrm{~mL}$ DMF dropwise. The reaction was warmed to rt and stirred for ca. $4 \mathrm{~h}$, then cooled to $0^{\circ} \mathrm{C}$ and quenched by adding $2 \mathrm{~mL}$ aqueous $\mathrm{pH} 7$ buffer. 5 $\mathrm{mL}$ dichloromethane was added and sodium chloride was added to saturate the aqueous layer. The organic layer was separated, and the aqueous layer was extracted with dichloromethane (15 $\mathrm{mL} \times 3$ ). The combined organic layers dried over anhydrous $\mathrm{Na}_{2} \mathrm{SO}_{4}$, filtered through a fritted glass funnel, rinsed with $10 \mathrm{~mL}$ dichloromethane and the filtrate was concentrated in vacuo to yield a crude film. Purification of the crude product by $\mathrm{SiO}_{2}$ flash column chromatography using gradient 
elution (3-7\% methanol in dichloromethane) afforded $1.5 \mathrm{mg}$ anhydroryanodol 25 as a white solid (38\% over 2 steps). ${ }^{i i}$

Spectral data for $25:{ }^{1} \mathrm{H}$ NMR $\left(600 \mathrm{MHz}, \mathrm{CD}_{3} \mathrm{OD}\right) \delta 4.71(\mathrm{q}, J=2.4 \mathrm{~Hz}, 1 \mathrm{H}), 3.99(\mathrm{~d}, J=10.4$ $\mathrm{Hz}, 1 \mathrm{H}), 3.62(\mathrm{~d}, J=19.8 \mathrm{~Hz}, 1 \mathrm{H}), 2.75$ (hept, $J=6.9 \mathrm{~Hz}, 1 \mathrm{H}), 2.30(\mathrm{~d}, J=19.8 \mathrm{~Hz}, 1 \mathrm{H}), 1.84-1.74(\mathrm{~m}$, $1 \mathrm{H}), 1.77(\mathrm{~d}, J=2.4 \mathrm{~Hz}, 3 \mathrm{H}), 1.63-1.43(\mathrm{~m}, 4 \mathrm{H}), 1.18(\mathrm{~s}, 3 \mathrm{H}), 1.15(\mathrm{~d}, J=6.9 \mathrm{~Hz}, 3 \mathrm{H}), 1.11(\mathrm{~d}, J=7.1$ $\mathrm{Hz}, 3 \mathrm{H}), 1.08(\mathrm{~d}, J=6.5 \mathrm{~Hz}, 3 \mathrm{H})$; $^{13} \mathrm{C} \mathrm{NMR}\left(150 \mathrm{MHz}, \mathrm{CD}_{3} \mathrm{OD}\right) \delta 173.2,148.4,134.3,93.5,92.9,90.4$, 84.7, 84.0, 72.8, 48.9, 40.4, 35.2, 28.8, 28.5, 26.2, 21.6, 19.3, 18.8, 14.7, 12.2; IR (thin film): 3411, $2965,2926,2870,1721,1320,1254,1160,1087,1024 \mathrm{~cm}^{-1}$; HRMS (ESI) calculated for $\mathrm{C}_{20} \mathrm{H}_{29} \mathrm{O}_{7}$ $\left[\mathrm{M}-\mathrm{H}^{+}\right]$381.1913; found, 381.1904 .

ii As previously discussed by Reisman-ref.9, due to the potential formation of borate complex between anhydroryanodol and leached $\mathrm{B}_{2} \mathrm{O}_{3}$ from borosilicate glassware. Soda-lime disposable culture tubes were used for fraction collection during silica gel chromatography. Quartz glassware were used to collect all the fractions and concentrate. Quartz NMR tubes were used for NMR experiment. 


\section{NMR Data Comparison of Anhydroryanodol between literature and this Report}

Comparison ${ }^{1} \mathrm{H}$ NMR data of Synthetic Anhydroryanodol between literature and this report

\begin{tabular}{|c|c|c|}
\hline \multirow[t]{2}{*}{ Carbon number } & $\begin{array}{c}\text { Synthetic Data from } \\
\text { Reisman's Lab, } 2016 \text { (ref. 9) } \\
\left(500 \mathrm{MHz}, \mathrm{CD}_{3} \mathrm{OD}\right)\end{array}$ & $\begin{array}{c}\text { Synthetic } \\
\text { This report } \\
\left(600 \mathrm{MHz}, \mathrm{CD}_{3} \mathrm{OD}\right)\end{array}$ \\
\hline & ${ }^{1} \mathrm{H}[\delta$, multi., J $(\mathrm{Hz})]$, & ${ }^{1} \mathrm{H}[\delta$, multi., J $(\mathrm{Hz})]$, \\
\hline 1 & - & - \\
\hline 2 & - & - \\
\hline 3 & $4.71(q, J=2.3 \mathrm{~Hz}, 1 \mathrm{H})$ & $4.71(q, J=2.4 \mathrm{~Hz}, 1 \mathrm{H})$ \\
\hline 4 & - & - \\
\hline 5 & - & - \\
\hline 6 & - & - \\
\hline 7,8 & $1.62-1.43(\mathrm{~m}, 4 \mathrm{H})$ & $1.63-1.43(\mathrm{~m}, 4 \mathrm{H})$ \\
\hline 9 & $1.84-1.74(\mathrm{~m}, 1 \mathrm{H})$ & $1.84-1.74(\mathrm{~m}, 1 \mathrm{H})$ \\
\hline 10 & $3.98(\mathrm{~d}, J=10.4 \mathrm{~Hz}, 1 \mathrm{H})$ & $3.99(\mathrm{~d}, J=10.4 \mathrm{~Hz}, 1 \mathrm{H})$ \\
\hline 11 & - & - \\
\hline 12 & - & - \\
\hline 13 & 2.75 (hept, $J=7.0 \mathrm{~Hz}, 1 \mathrm{H}$ ) & 2.75 (hept, $J=6.9 \mathrm{~Hz}, 1 \mathrm{H}$ ) \\
\hline $14 a$ & $3.62(\mathrm{~d}, J=19.9 \mathrm{~Hz}, 1 \mathrm{H})$ & $3.62(\mathrm{~d}, J=19.8 \mathrm{~Hz}, 1 \mathrm{H})$ \\
\hline $14 \mathrm{~b}$ & $2.30(\mathrm{~d}, J=19.8 \mathrm{~Hz}, 1 \mathrm{H})$ & $2.30(\mathrm{~d}, J=19.8 \mathrm{~Hz}, 1 \mathrm{H})$ \\
\hline 15 & - & - \\
\hline 17 & $1.77(\mathrm{~d}, J=2.4 \mathrm{~Hz}, 3 \mathrm{H})$ & $1.77(\mathrm{~d}, J=2.4 \mathrm{~Hz}, 3 \mathrm{H})$ \\
\hline 18 & $1.15(\mathrm{~d}, J=7.0 \mathrm{~Hz}, 3 \mathrm{H})$ & $1.15(\mathrm{~d}, J=6.9 \mathrm{~Hz}, 3 \mathrm{H})$ \\
\hline 19 & $1.11(\mathrm{~d}, J=7.0 \mathrm{~Hz}, 3 \mathrm{H})$ & $1.11(\mathrm{~d}, J=7.1 \mathrm{~Hz}, 3 \mathrm{H})$ \\
\hline 20 & $1.18(\mathrm{~s}, 3 \mathrm{H})$ & $1.18(\mathrm{~s}, 3 \mathrm{H})$ \\
\hline 21 & $1.08(\mathrm{~d}, J=6.5 \mathrm{~Hz}, 3 \mathrm{H})$ & $1.08(\mathrm{~d}, J=6.5 \mathrm{~Hz}, 3 \mathrm{H})$ \\
\hline
\end{tabular}


Comparison ${ }^{13} \mathrm{C}$ NMR data of Synthetic Anhydroryanodol between literature and this report

\begin{tabular}{|c|c|c|c|}
\hline Carbon Number & $\begin{array}{c}\text { Synthetic Data from } \\
\text { Reisman's Lab, } 2016 \\
\text { (ref. 9) } \\
\left(126 \mathrm{MHz}, \mathrm{CD}_{3} \mathrm{OD}\right)\end{array}$ & $\begin{array}{c}\text { Synthetic } \\
\text { This Report } \\
\left(150 \mathrm{MHz}, \mathrm{CD}_{3} \mathrm{OD}\right)\end{array}$ & $\begin{array}{c}\text { Chemical Shift } \\
\text { Difference } \\
(\Delta \delta)\end{array}$ \\
\hline & ${ }^{13} \mathrm{C}(\delta) \mathrm{ppm}$ & ${ }^{13} \mathrm{C}(\delta) \mathrm{ppm}$ & ${ }^{13} \mathrm{C}(\Delta \delta)$ \\
\hline 1 & 134.2 & 134.3 & 0.1 \\
\hline 2 & 148.3 & 148.4 & 0.1 \\
\hline 3 & 84.0 & 84.0 & 0.0 \\
\hline 4 & 90.3 & 90.4 & 0.1 \\
\hline 5 & 48.9 & 48.9 & 0.0 \\
\hline 6 & 84.7 & 84.7 & 0.0 \\
\hline 7 & 26.1 & 26.2 & 0.1 \\
\hline 8 & 28.8 & 28.8 & 0.0 \\
\hline 9 & 35.2 & 35.2 & 0.0 \\
\hline 10 & 72.8 & 72.8 & 0.0 \\
\hline 11 & 92.8 & 92.9 & 0.1 \\
\hline 12 & 93.4 & 93.5 & 0.1 \\
\hline 13 & 28.5 & 28.5 & 0.0 \\
\hline 14 & 40.3 & 40.4 & 0.1 \\
\hline 15 & 173.2 & 173.2 & 0.0 \\
\hline 17 & 12.2 & 12.2 & 0.0 \\
\hline 18 & 19.3 & 19.3 & 0.0 \\
\hline 19 & 21.6 & 21.6 & 0.0 \\
\hline 20 & 14.7 & 14.7 & 0.0 \\
\hline 21 & 18.8 & 18.8 & 0.0 \\
\hline
\end{tabular}


4. NMR Data 


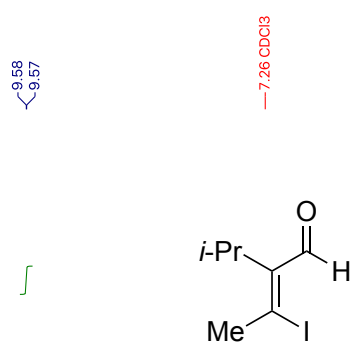

S1

${ }^{1} \mathrm{H}$ NMR $\left(600 \mathrm{MHz}, \mathrm{CDCl}_{3}\right)$

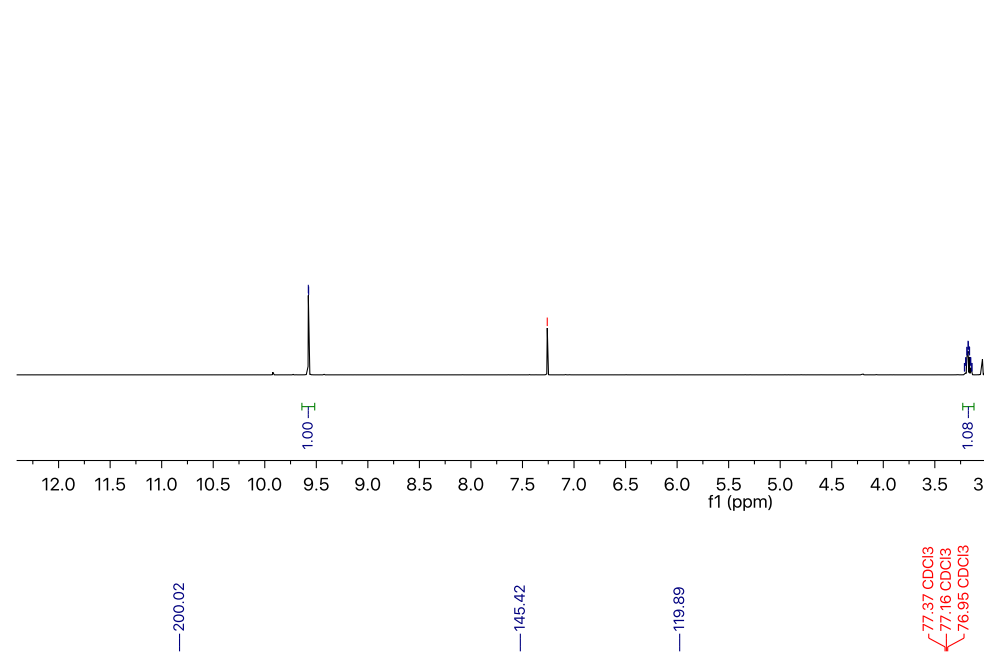

S1

${ }^{13} \mathrm{C}$ NMR $\left(150 \mathrm{MHz}, \mathrm{CDCl}_{3}\right)$
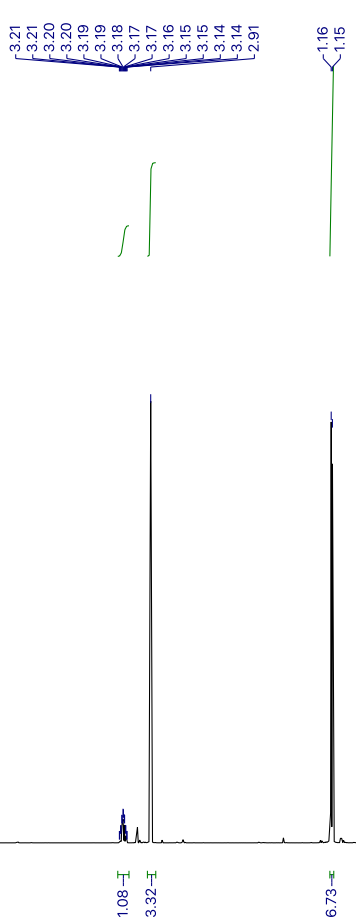

$\begin{array}{llllllllll}3.0 & 2.5 & 2.0 & 1.5 & 1.0 & 0.5 & 0.0 & -0.5 & -1.0 & -1.5\end{array}$

๙

30

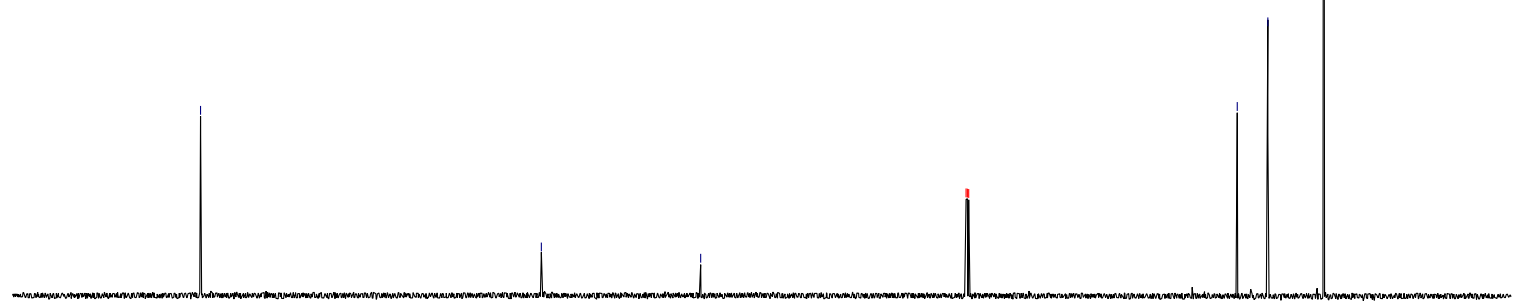

220

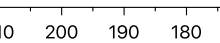

$170 \quad 160$

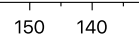

$1201110 \quad 100$

80

70

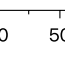




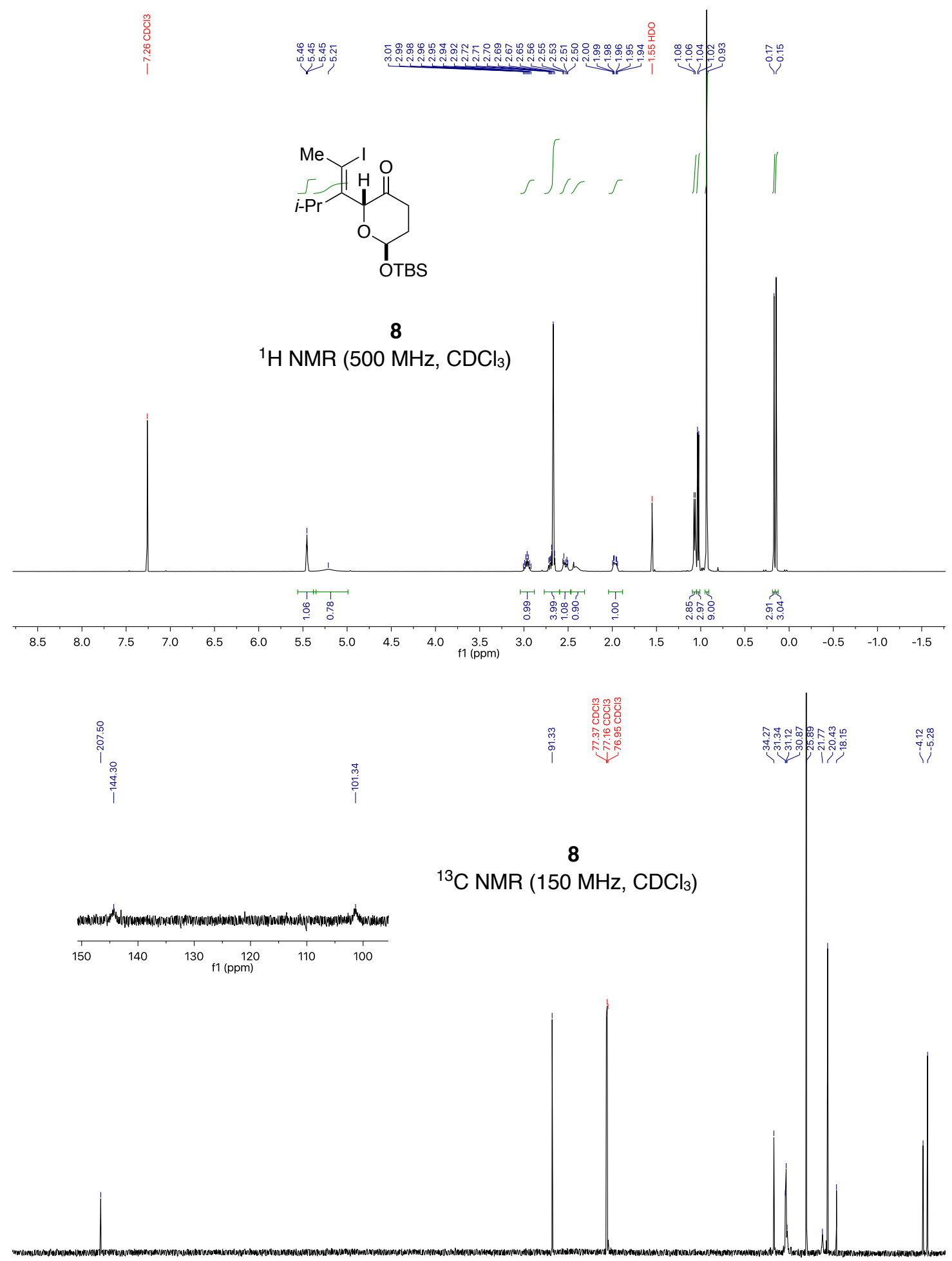

$\begin{array}{llllllllllllllllllllllllllllll}30 & 220 & 210 & 200 & 190 & 180 & 170 & 160 & 150 & 140 & 130 & 120 & \begin{array}{c}110 \\ \mathrm{f}(\mathrm{ppm})\end{array} & 100 & 90 & 80 & 70 & 60 & 50 & 40 & 30 & 20 & 10 & 0 & 0\end{array}$ 


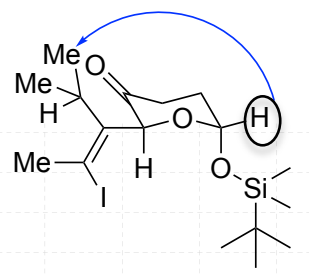

Selected 1D nOe of 8 (500 MHz, $\mathrm{CDCl}_{3}$ )
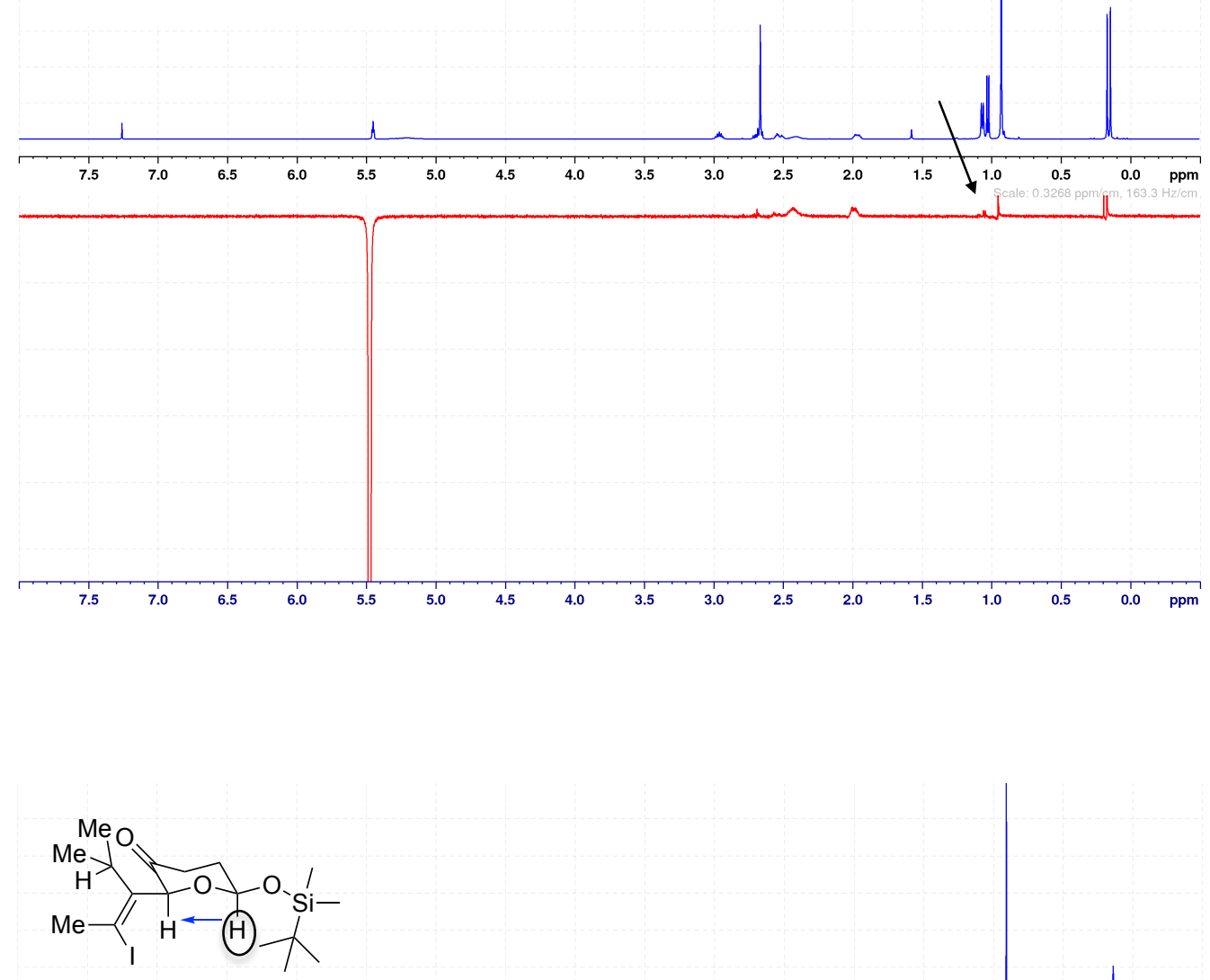

Selected 1D nOe of 9 $\left(500 \mathrm{MHz}, \mathrm{CDCl}_{3}\right.$ )

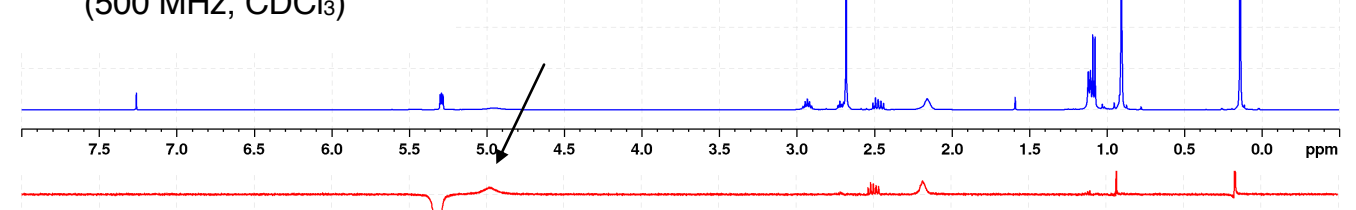



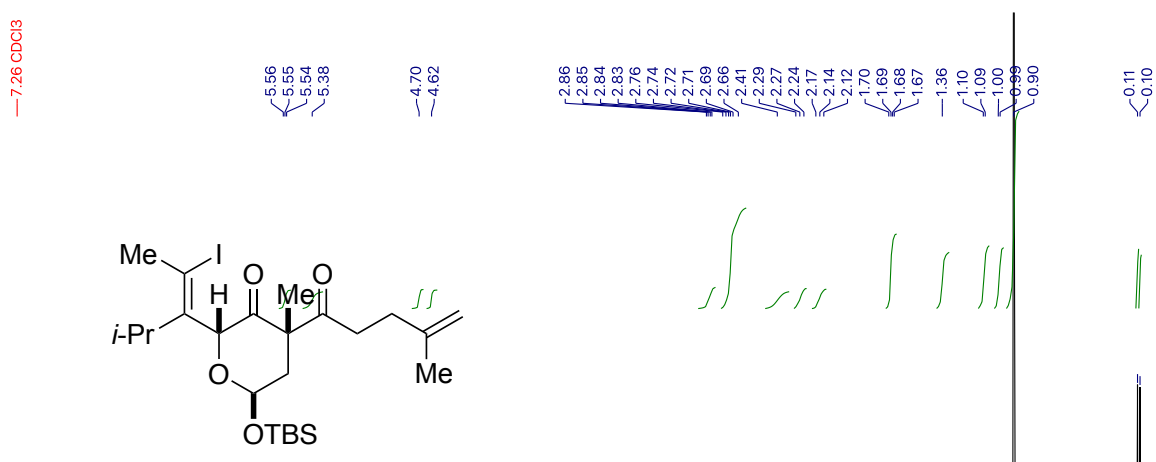

11

${ }^{1} \mathrm{H}$ NMR $\left(600 \mathrm{MHz}, \mathrm{CDCl}_{3}\right)$
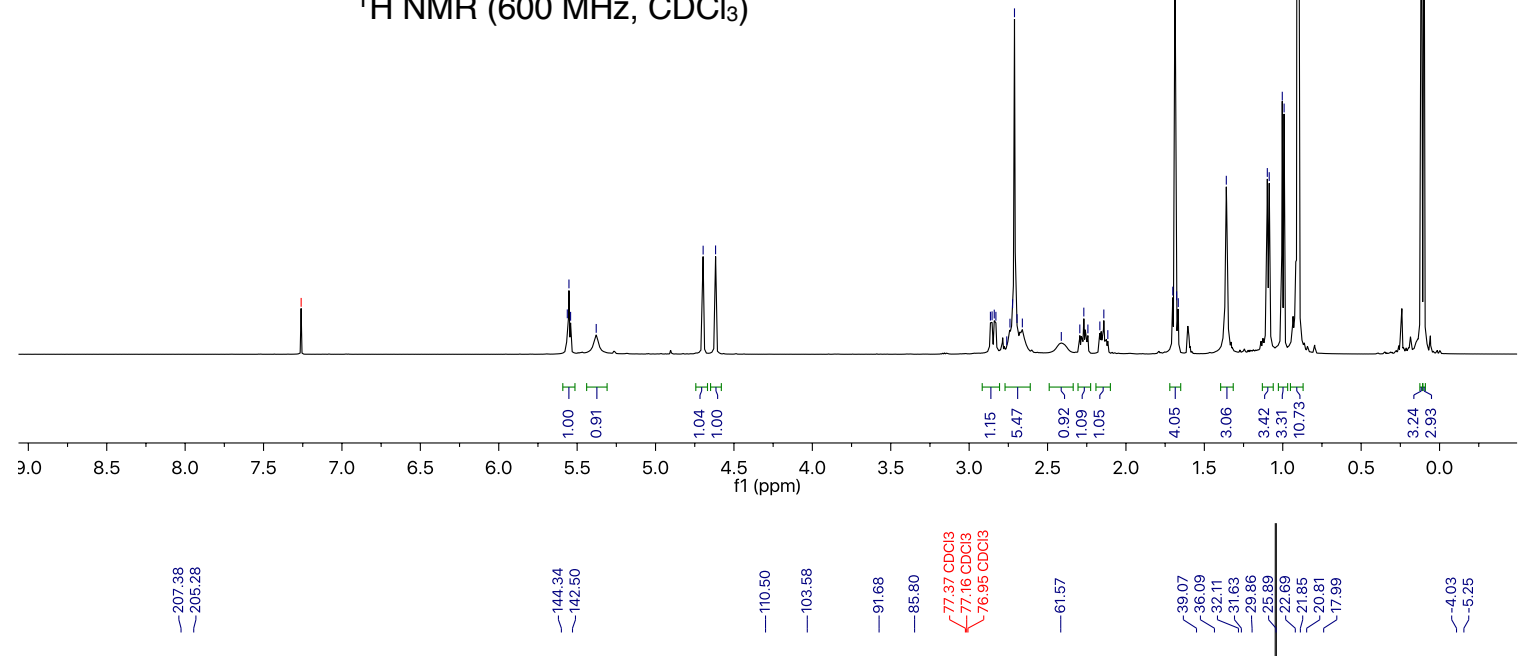

11

${ }^{13} \mathrm{C} \mathrm{NMR}\left(150 \mathrm{MHz}, \mathrm{CDCl}_{3}\right)$

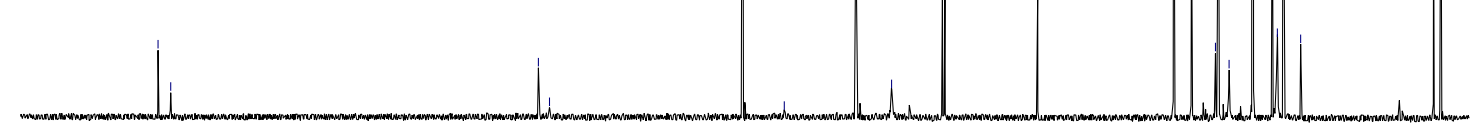

\begin{tabular}{lllllllllllllllllllllllllll}
\hline 30 & 220 & 210 & 200 & 190 & 180 & 170 & 160 & 150 & 140 & 130 & 120 & 110 & 100 & 90 & 80 & 70 & 60 & 50 & 40 & 30 & 20 & 10 & 0 &
\end{tabular} 


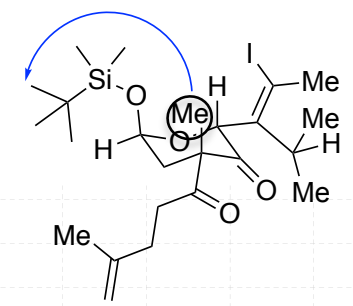

Selected 1D nOe of $\mathbf{1 1}$

$\left(500 \mathrm{MHz}, \mathrm{CDCl}_{3}\right)$
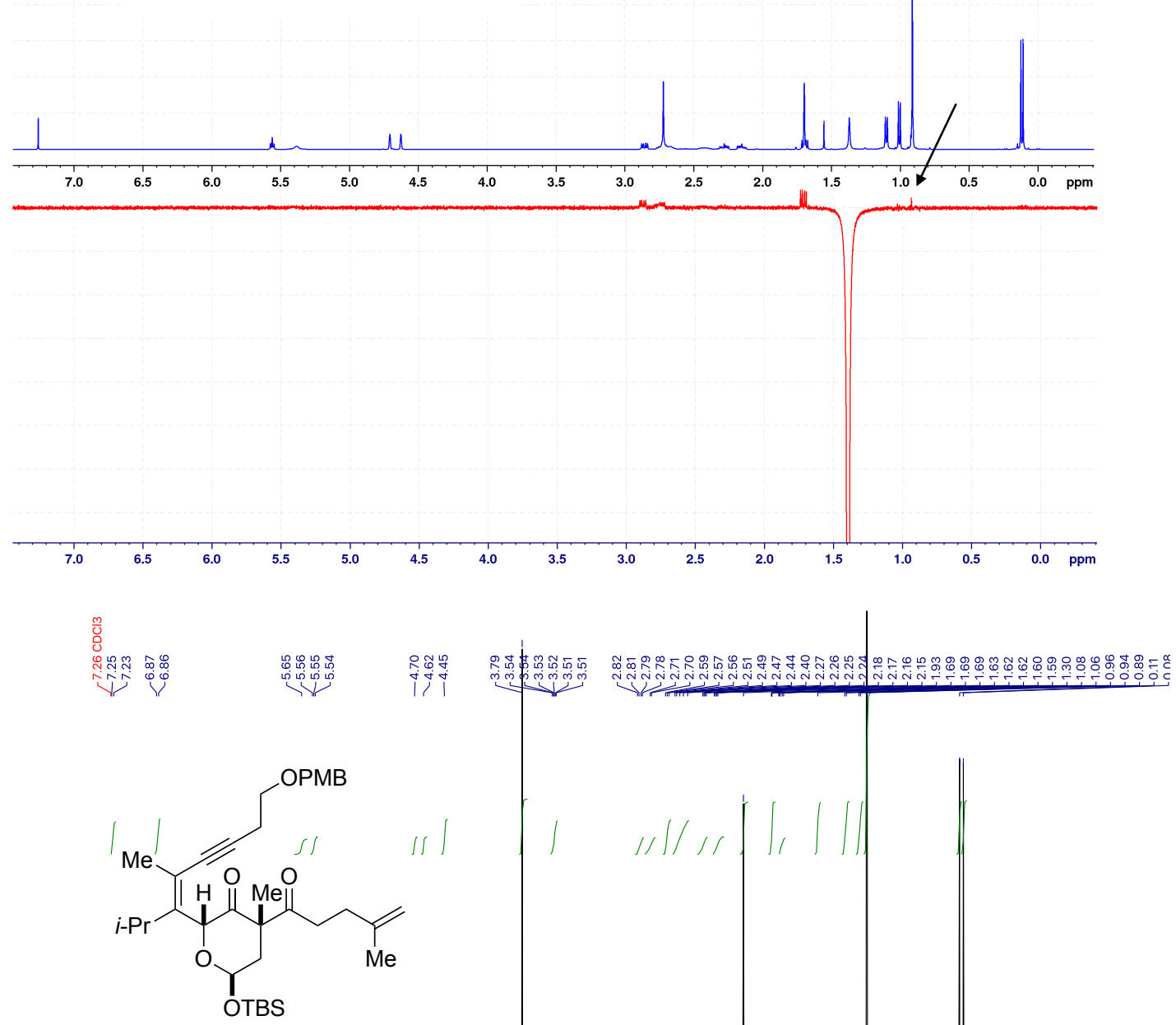

12

${ }^{1} \mathrm{H}$ NMR $\left(500 \mathrm{MHz}, \mathrm{CDCl}_{3}\right)$

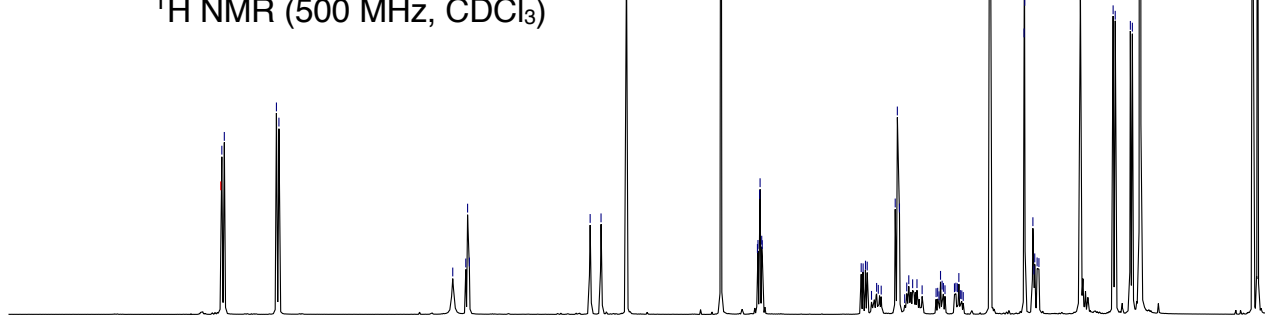

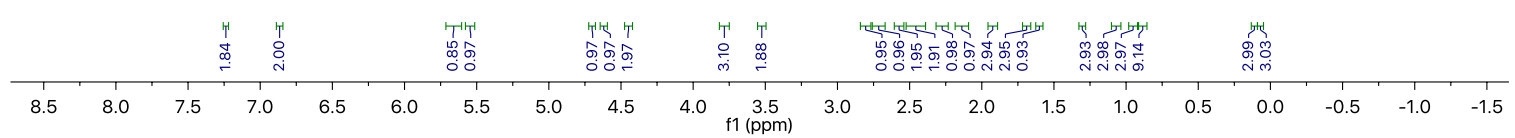




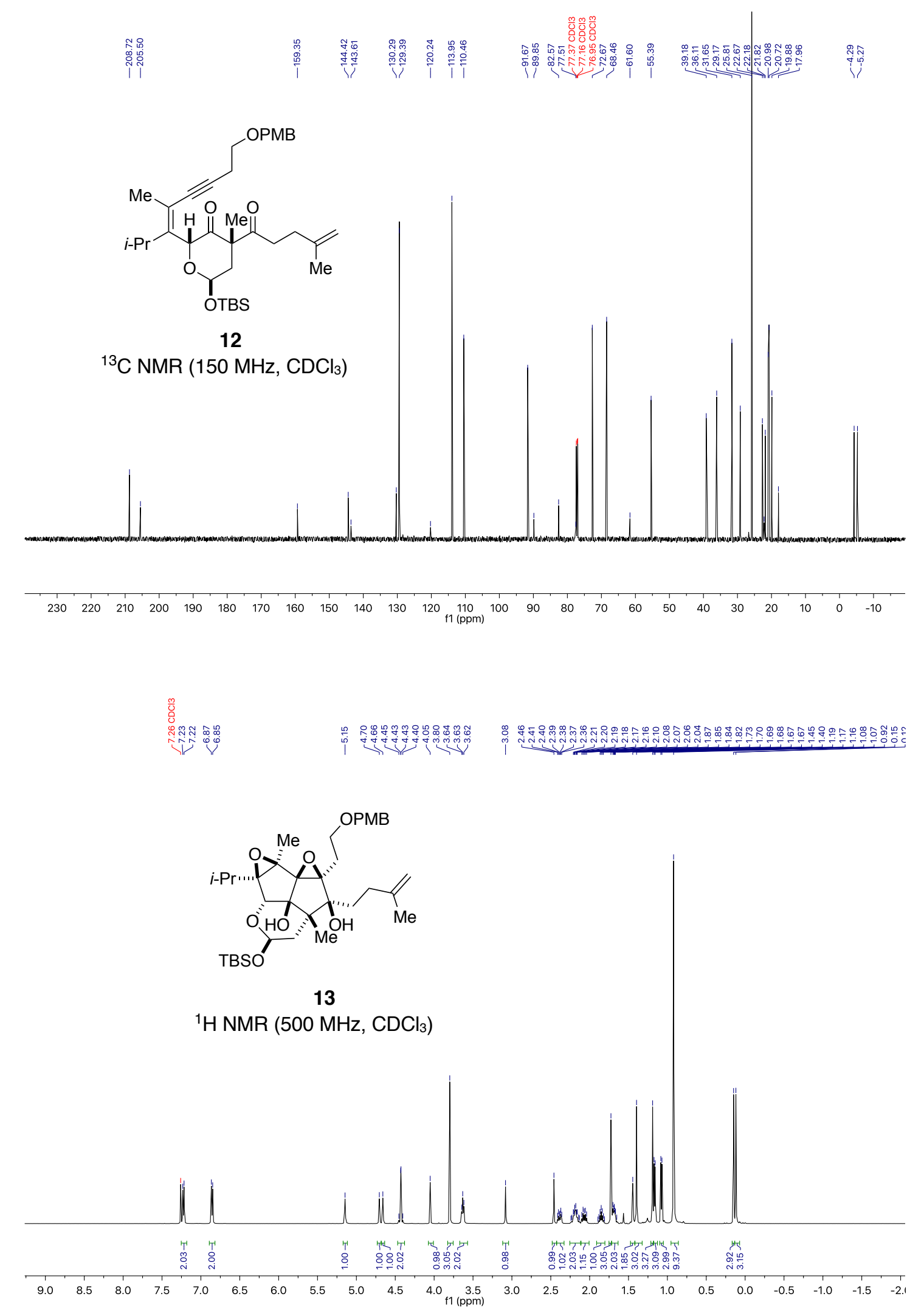



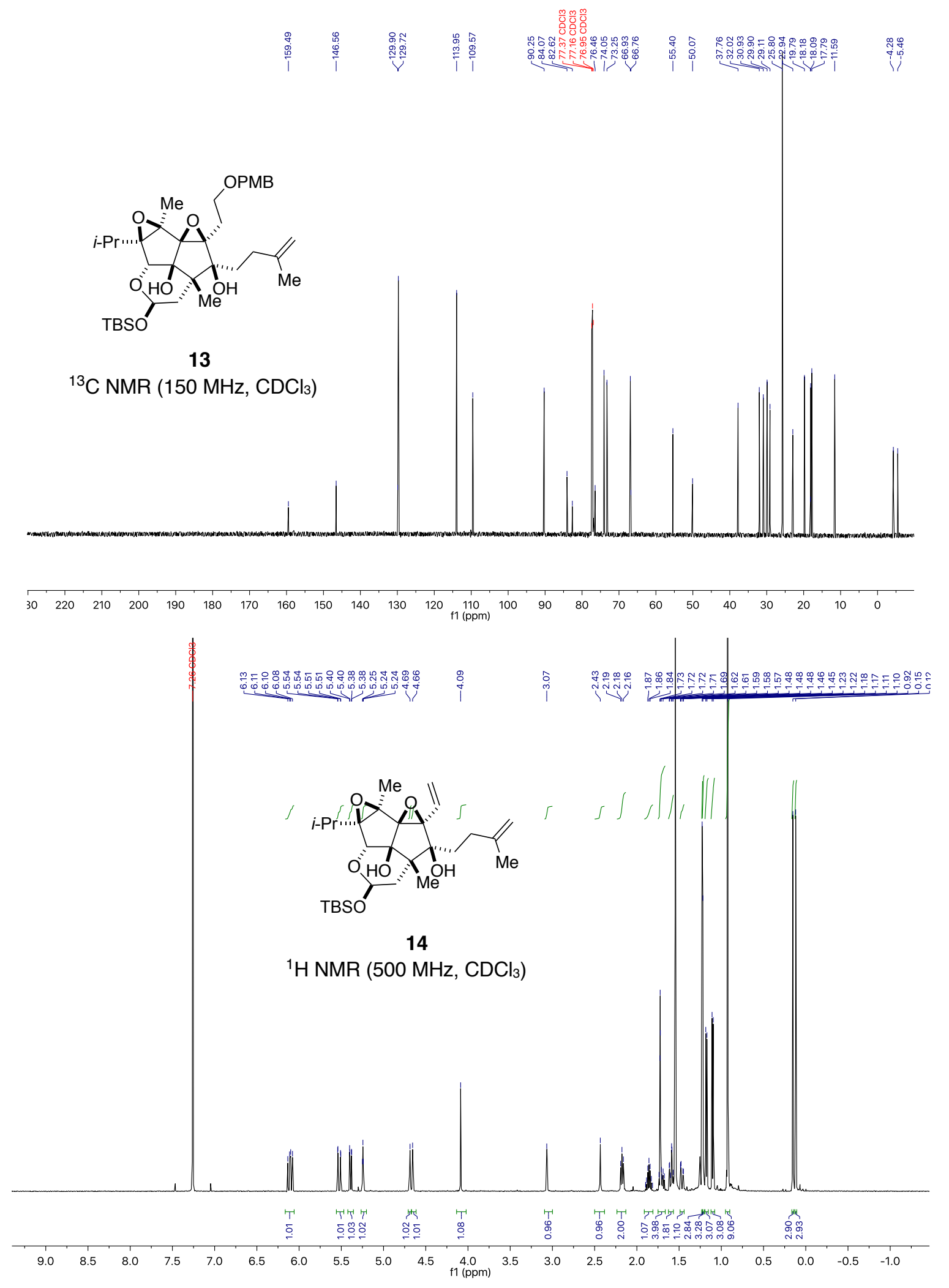

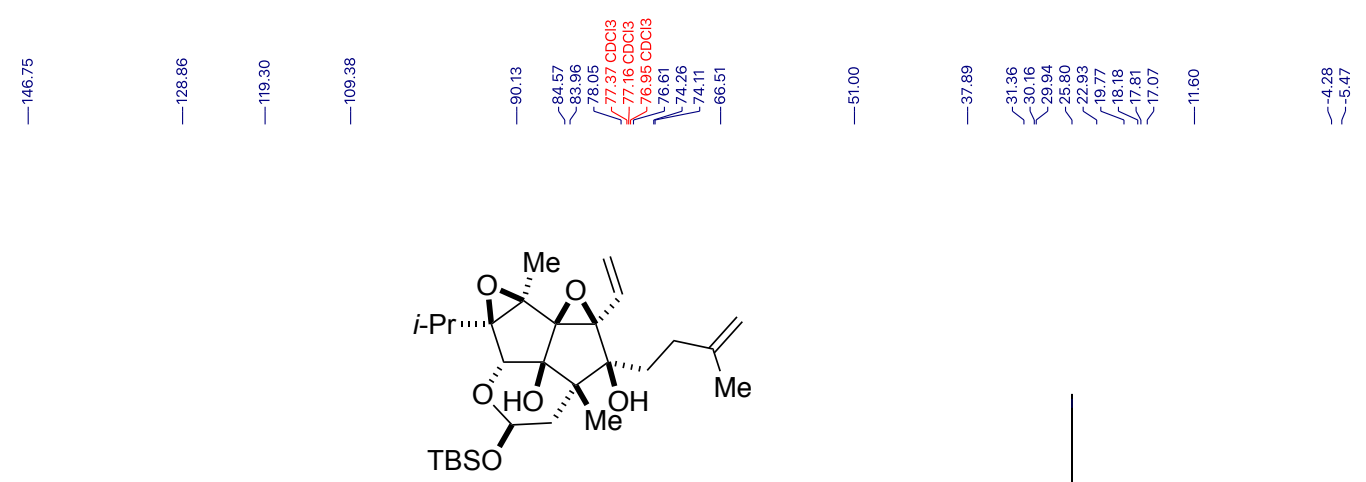

14

${ }^{13} \mathrm{C}$ NMR $\left(150 \mathrm{MHz}, \mathrm{CDCl}_{3}\right)$
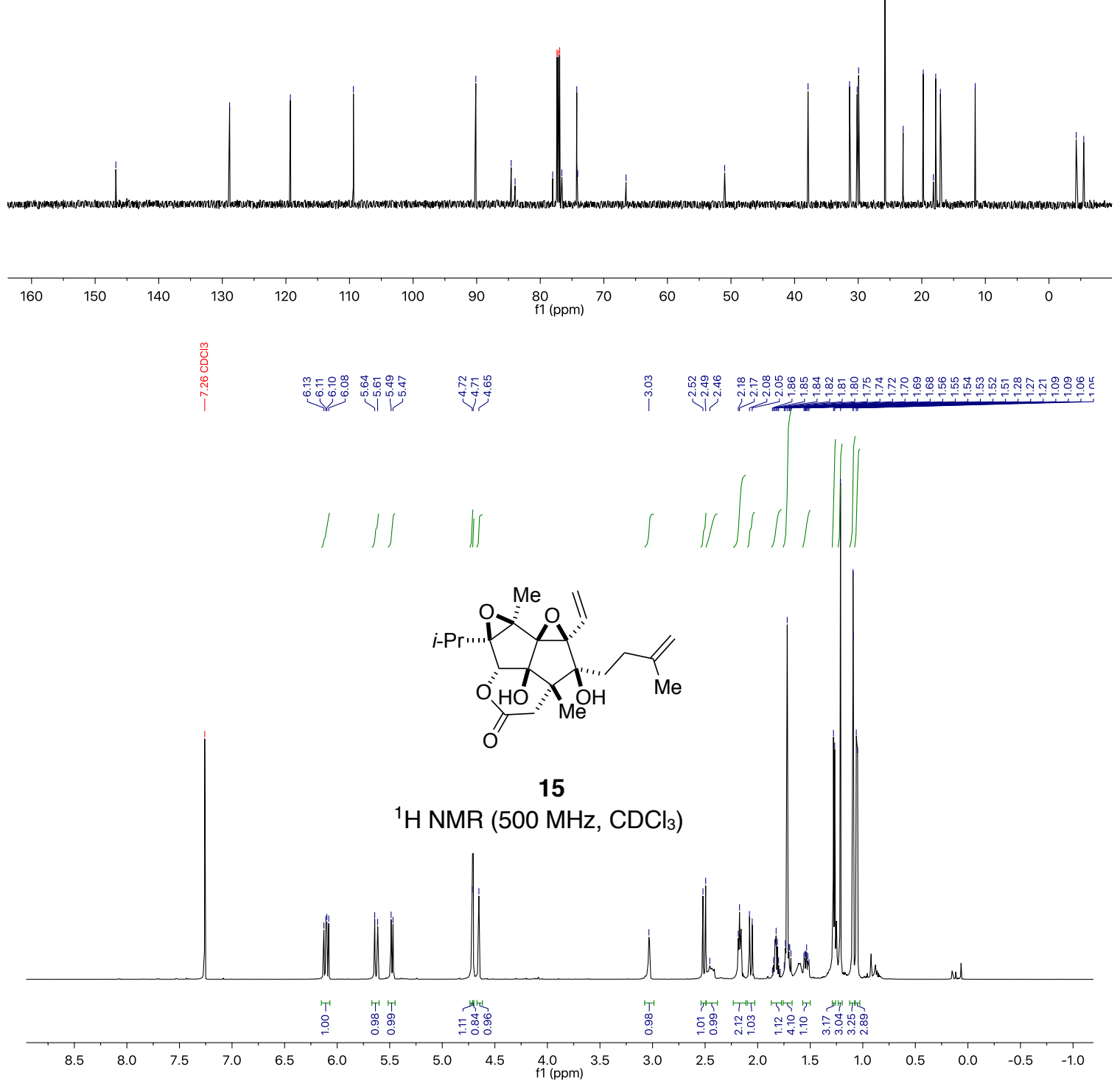


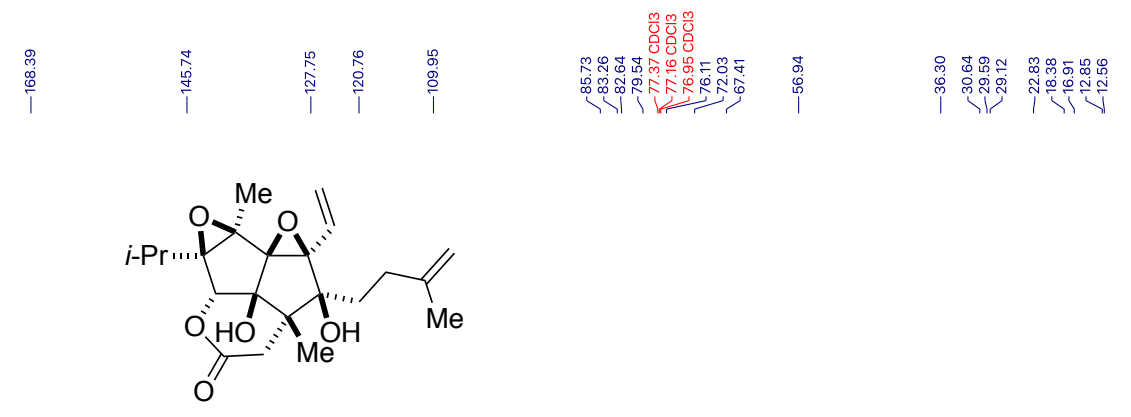

15

${ }^{13} \mathrm{C}$ NMR $\left(150 \mathrm{MHz}, \mathrm{CDCl}_{3}\right)$
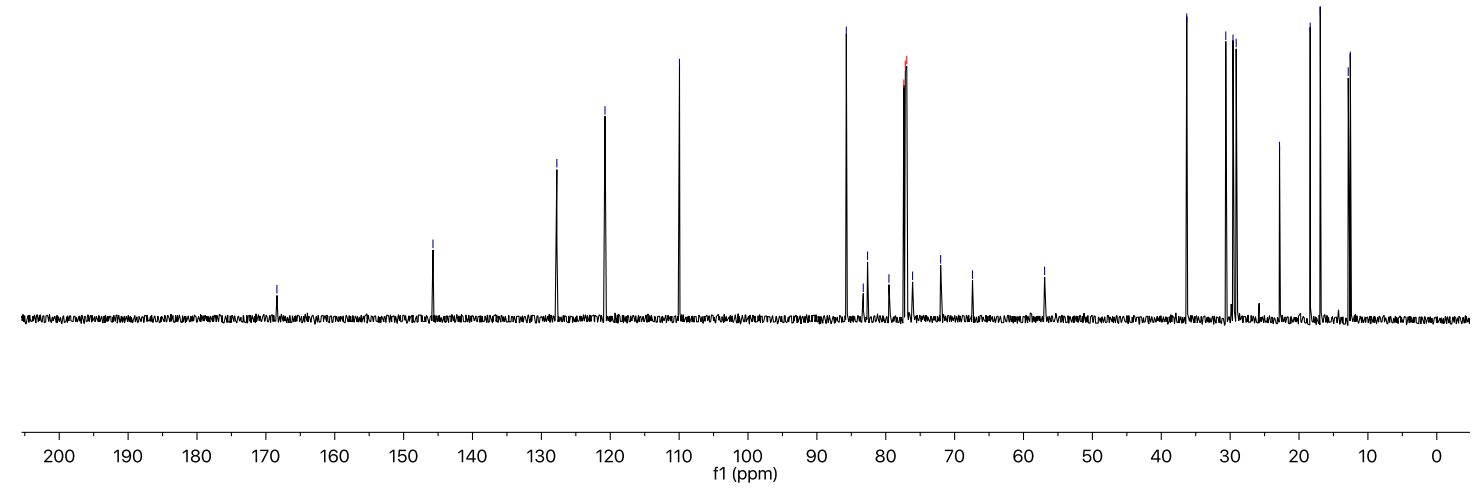

إن

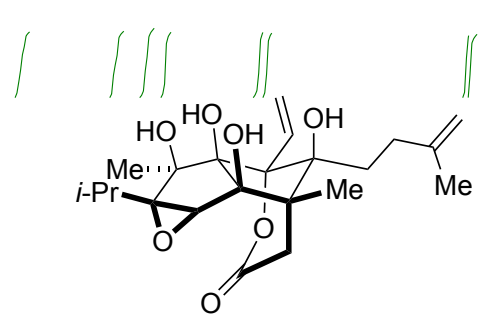

17

${ }^{1} \mathrm{H}$ NMR $\left(600 \mathrm{MHz}, \mathrm{CDCl}_{3}\right)$

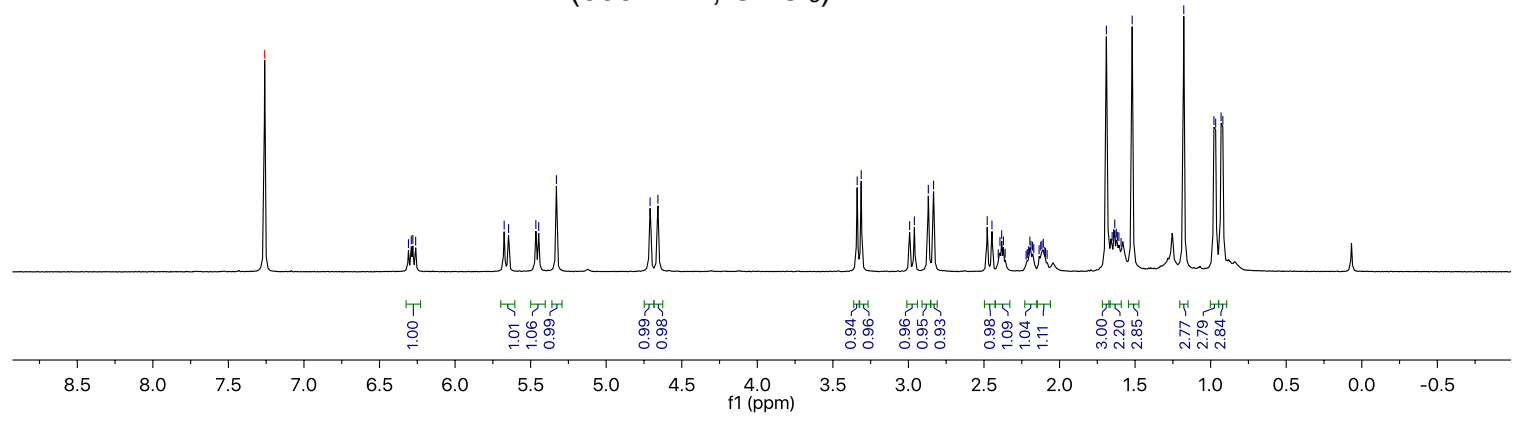



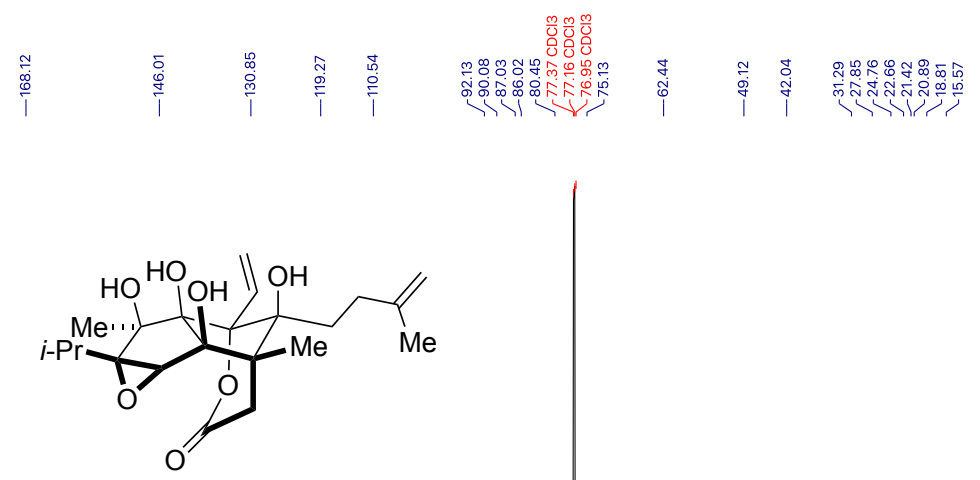

17

${ }^{13} \mathrm{C}$ NMR (150 MHz, $\left.\mathrm{CDCl}_{3}\right)$
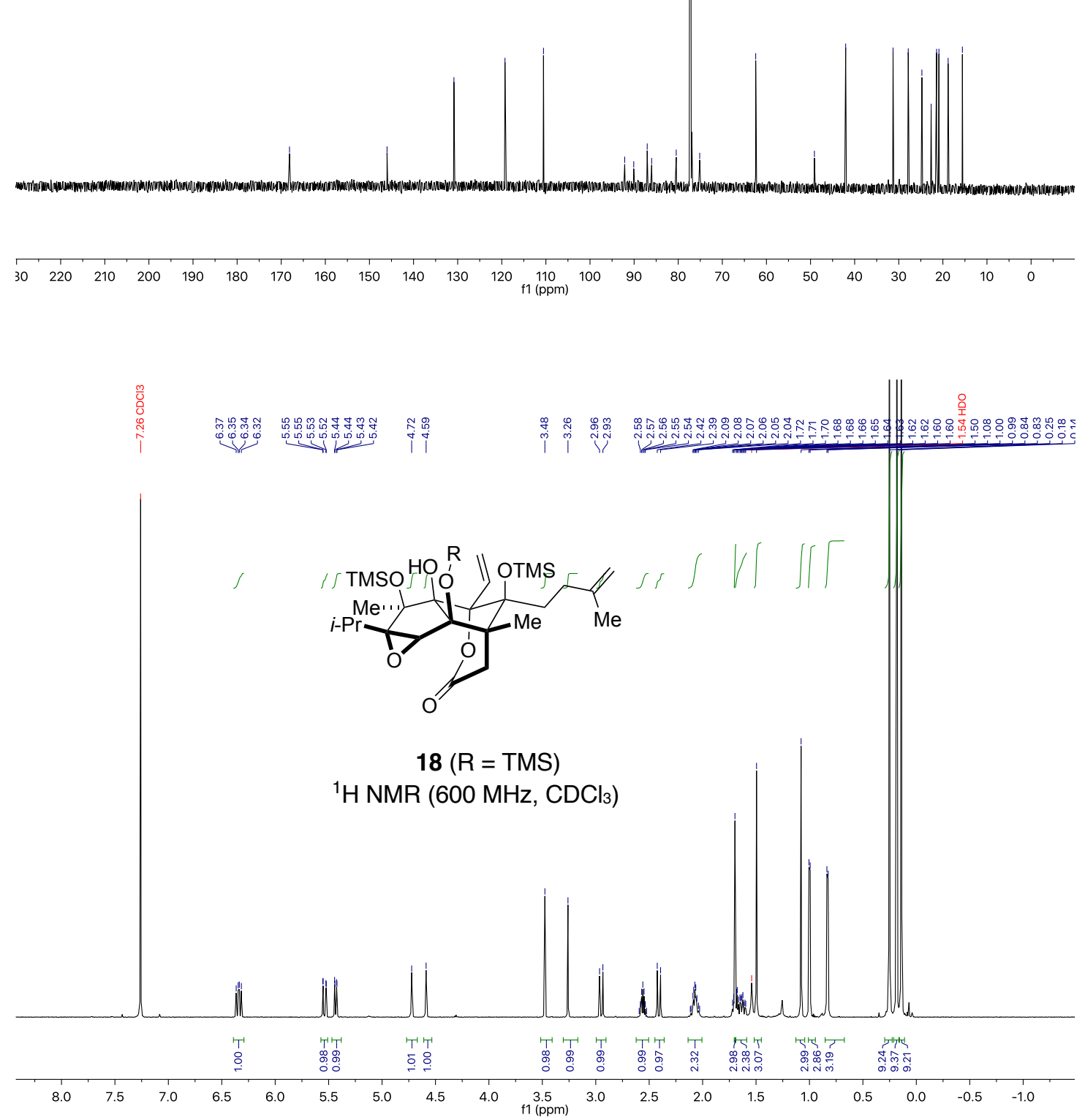

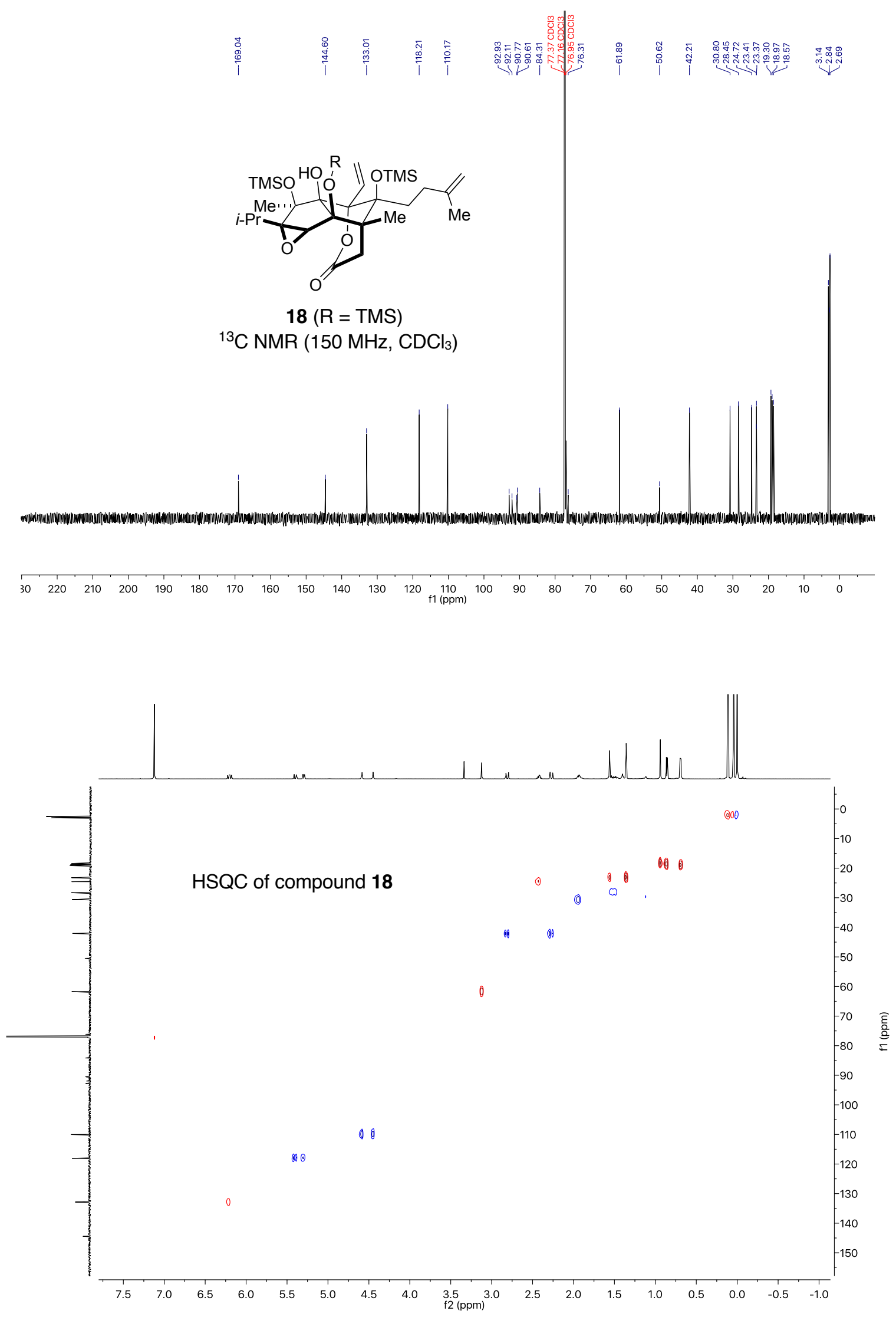


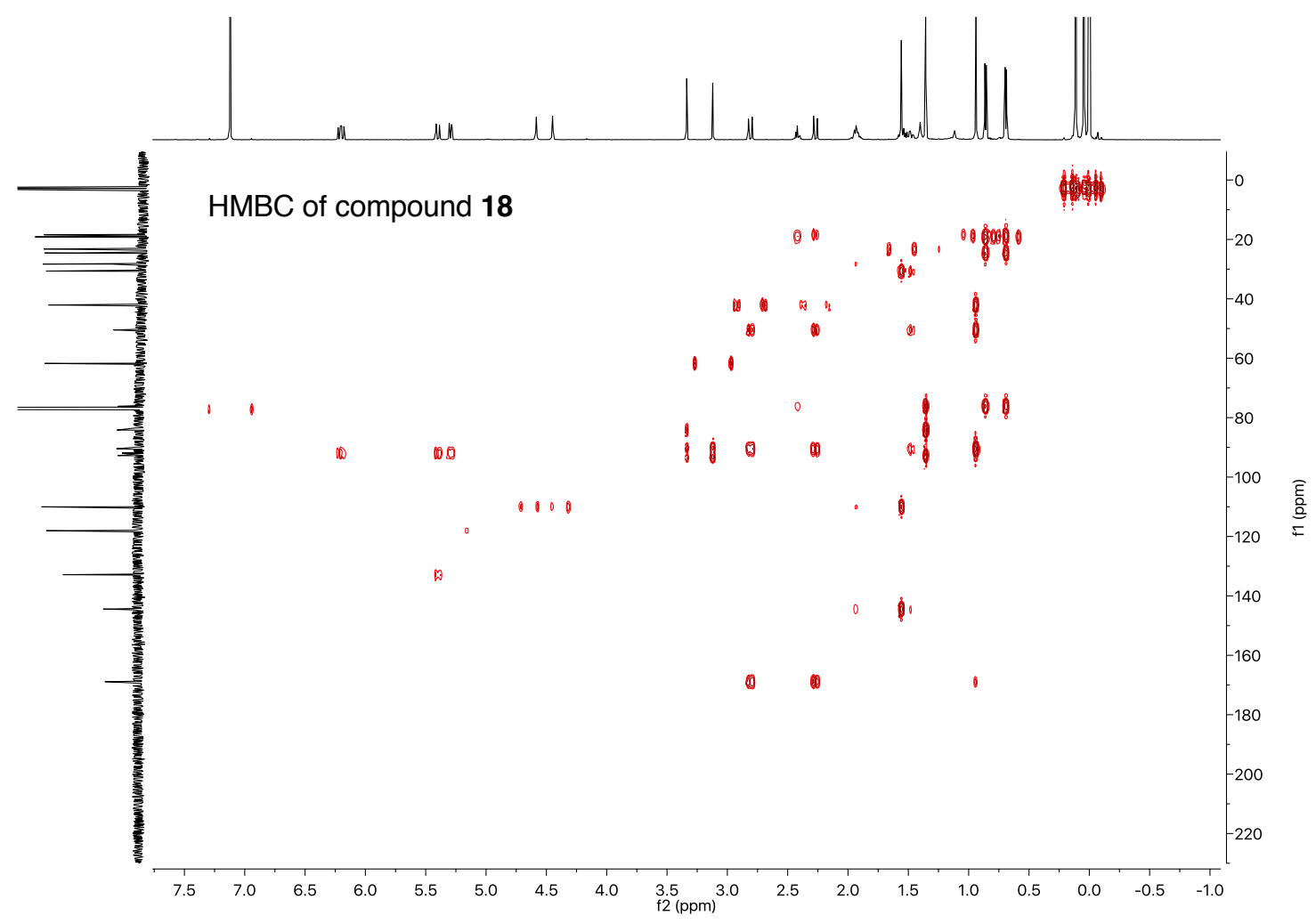

Selected 1D nOe of $\mathbf{1 8}$
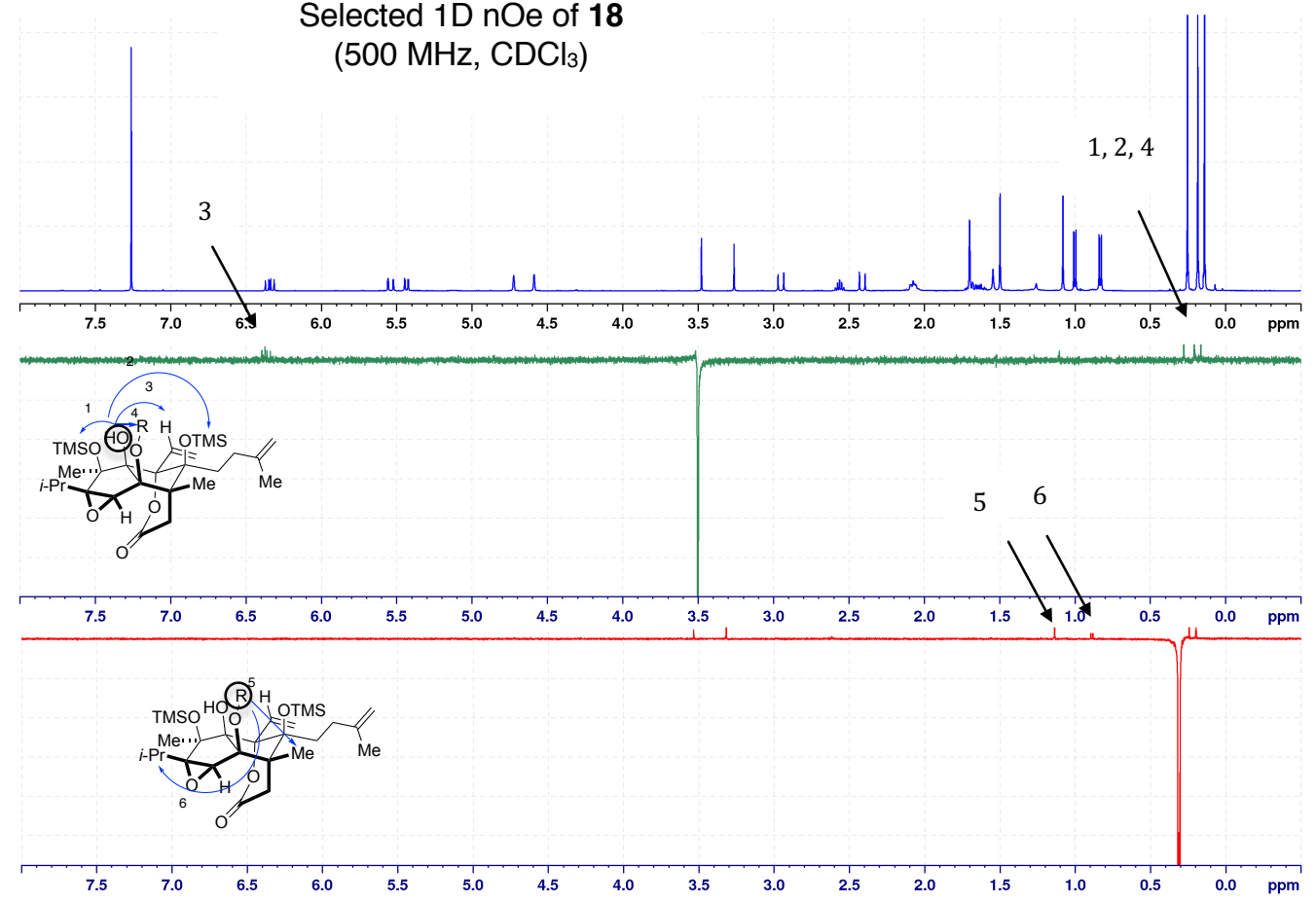


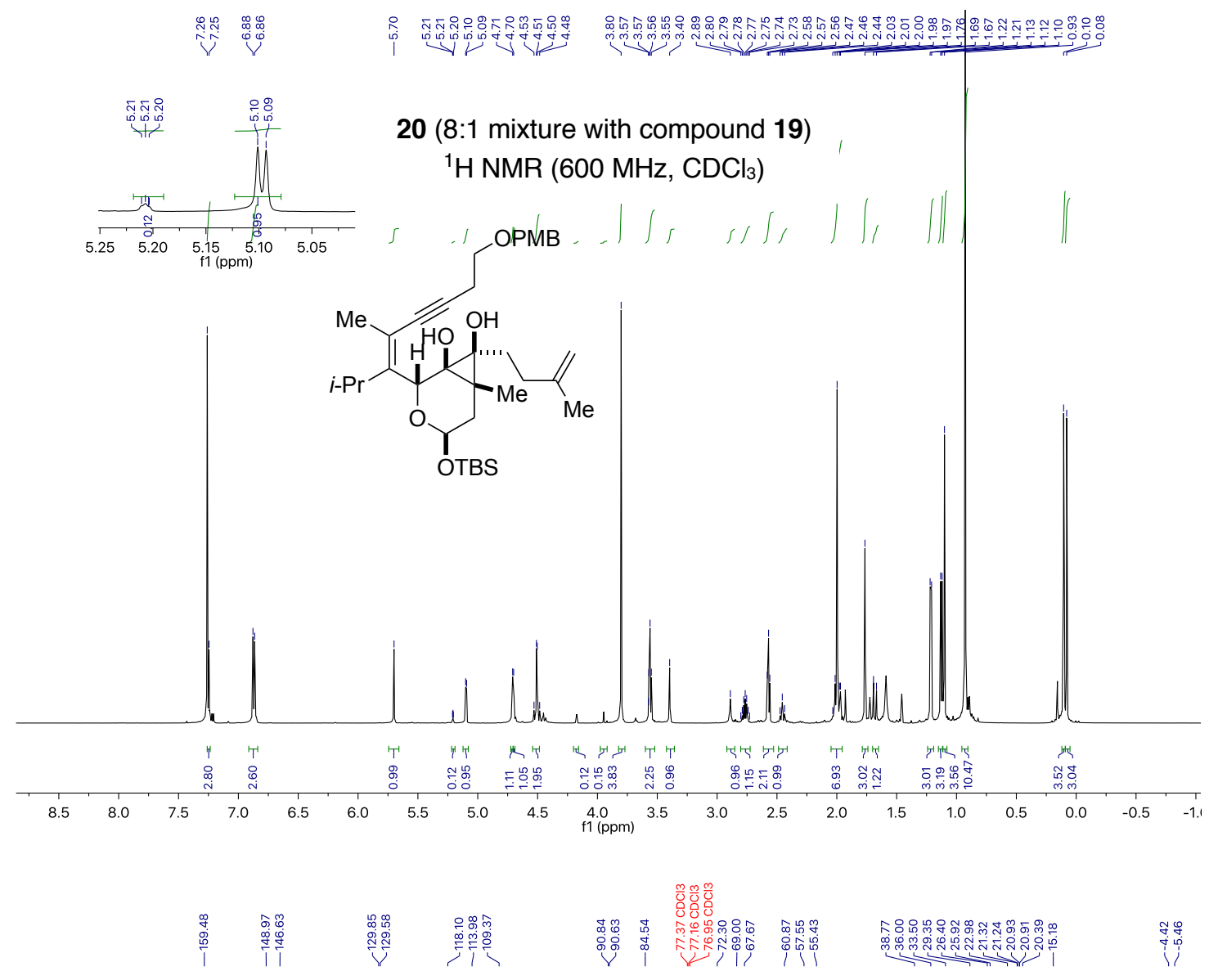

20 (8:1 mixture with compound 19)

${ }^{13} \mathrm{C} \mathrm{NMR}\left(150 \mathrm{MHz}, \mathrm{CDCl}_{3}\right)$

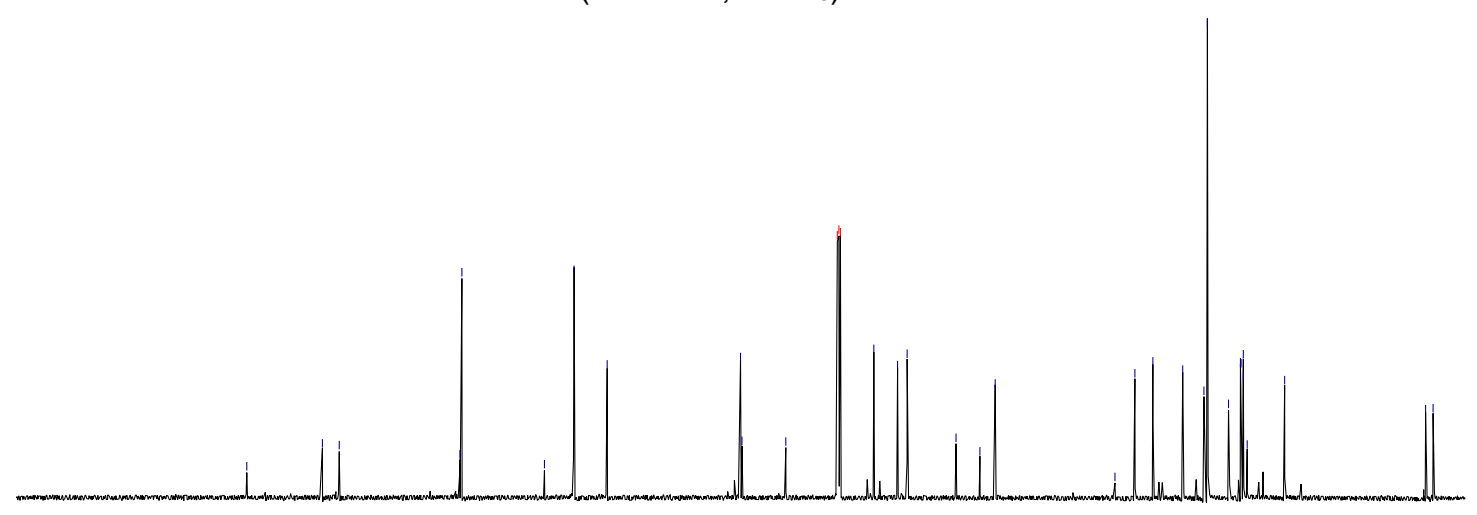

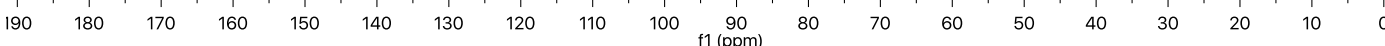



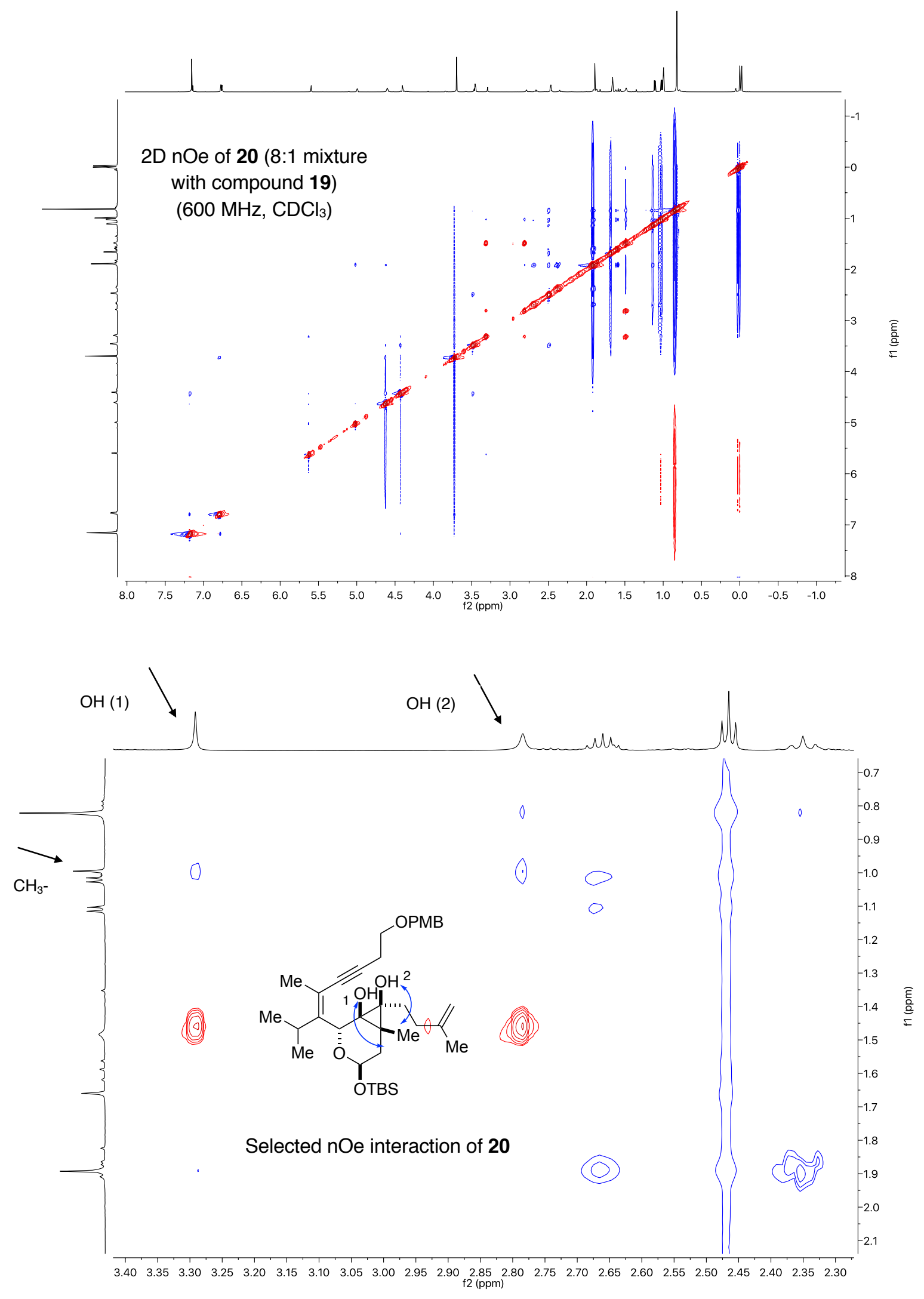


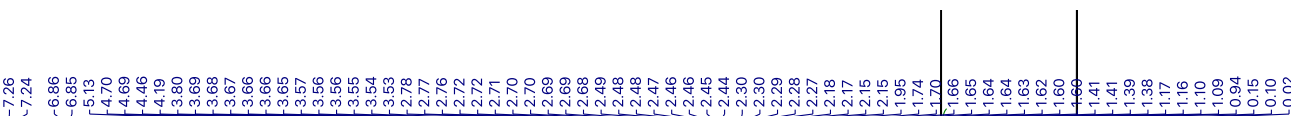

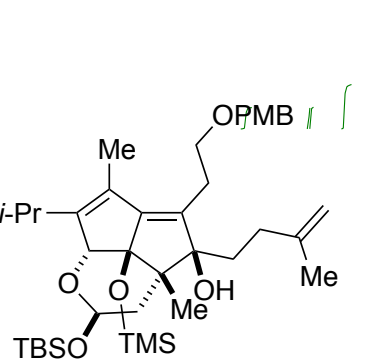

S8

${ }^{1} \mathrm{H} \mathrm{NMR}\left(600 \mathrm{MHz}, \mathrm{CDCl}_{3}\right)$

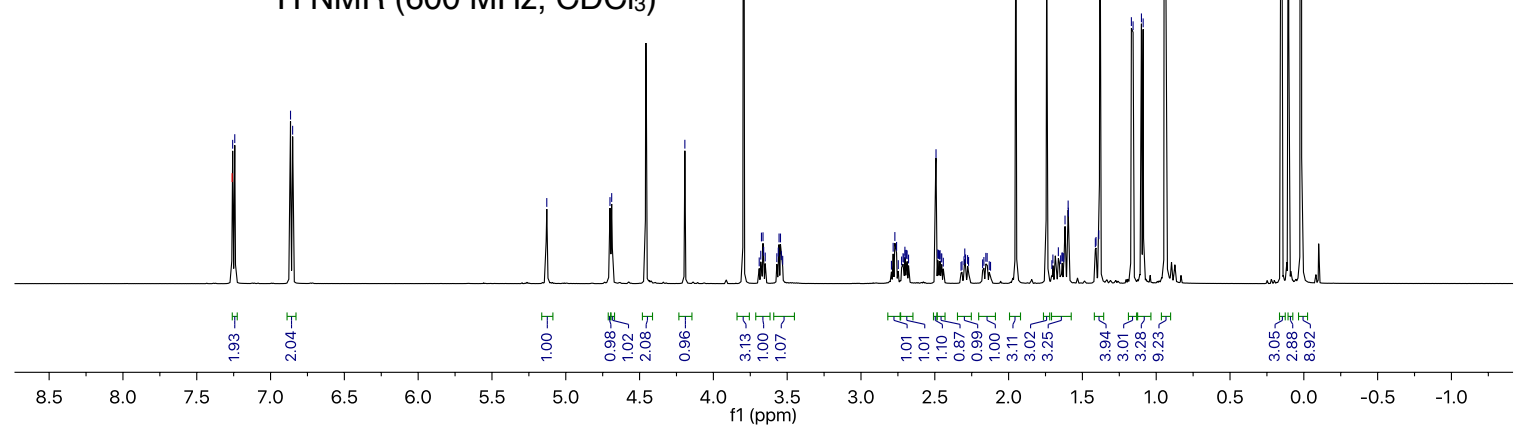

กิบ

l
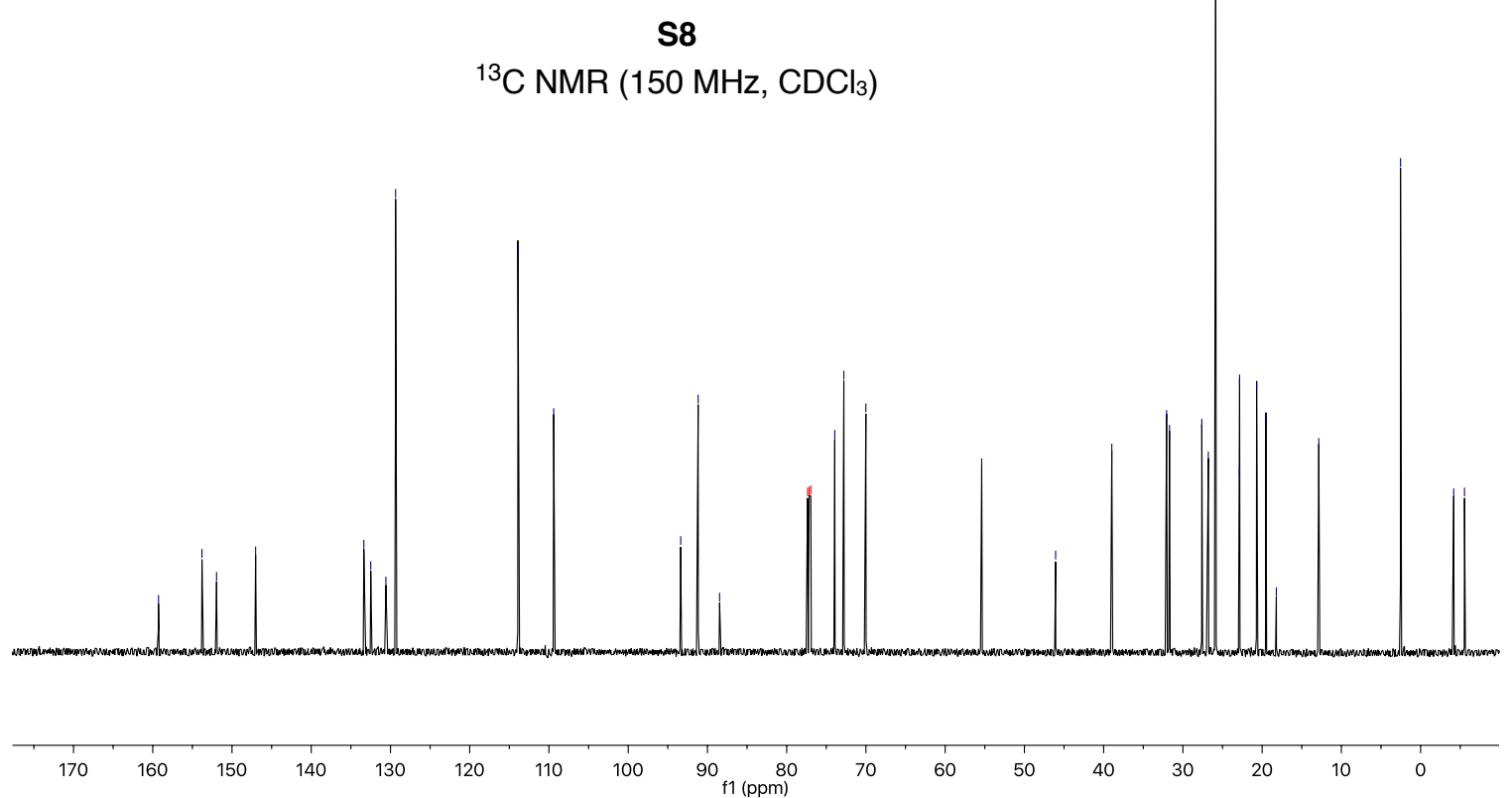


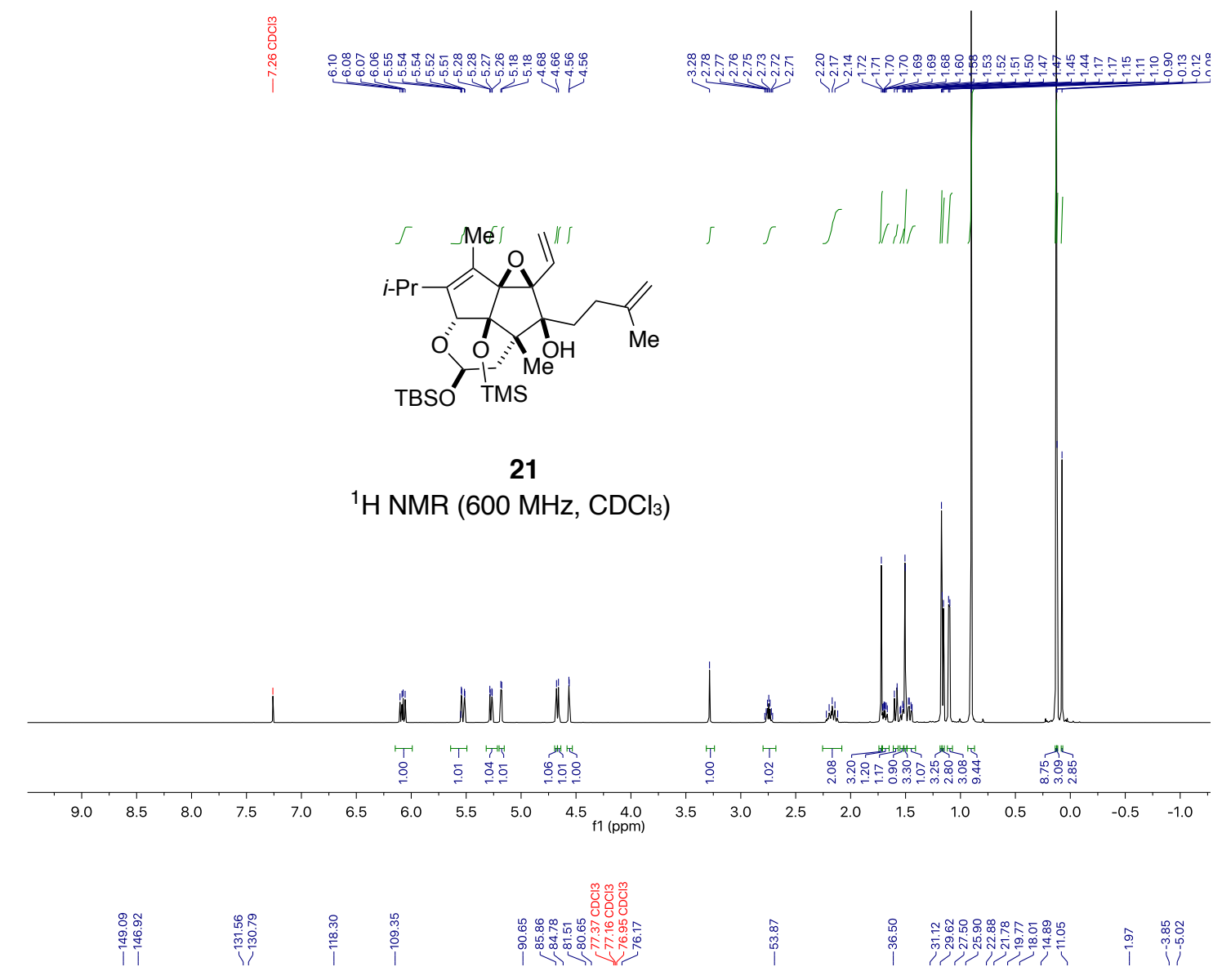

21

${ }^{13} \mathrm{C}$ NMR $\left(150 \mathrm{MHz}, \mathrm{CDCl}_{3}\right)$

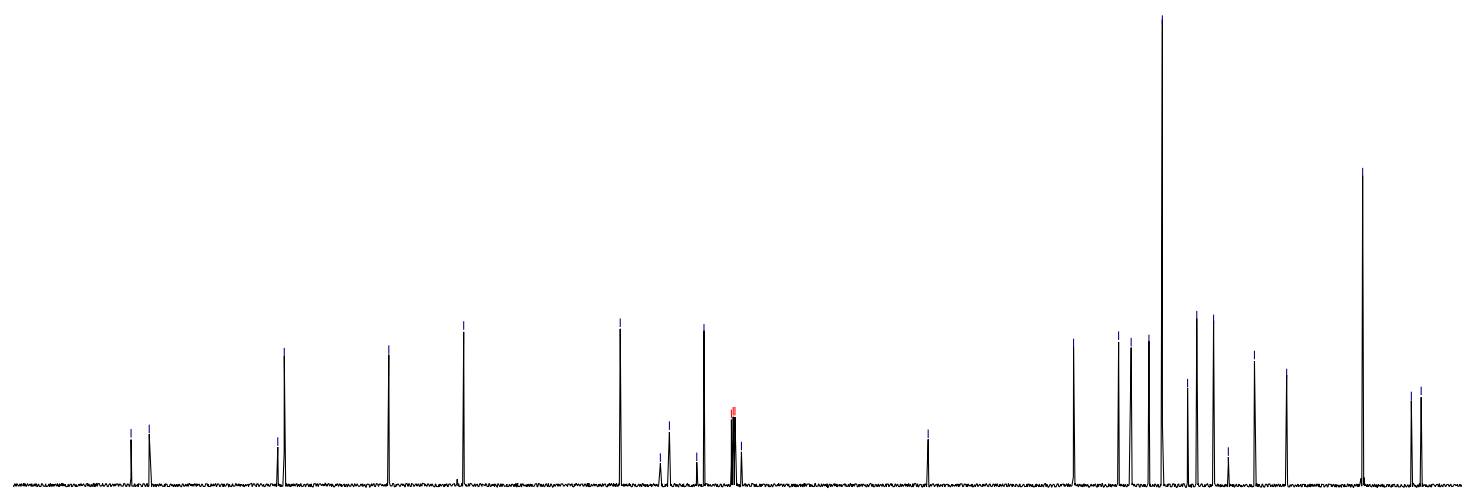

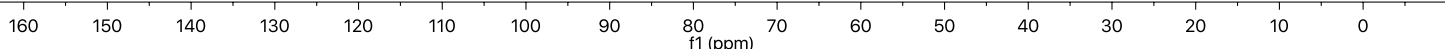



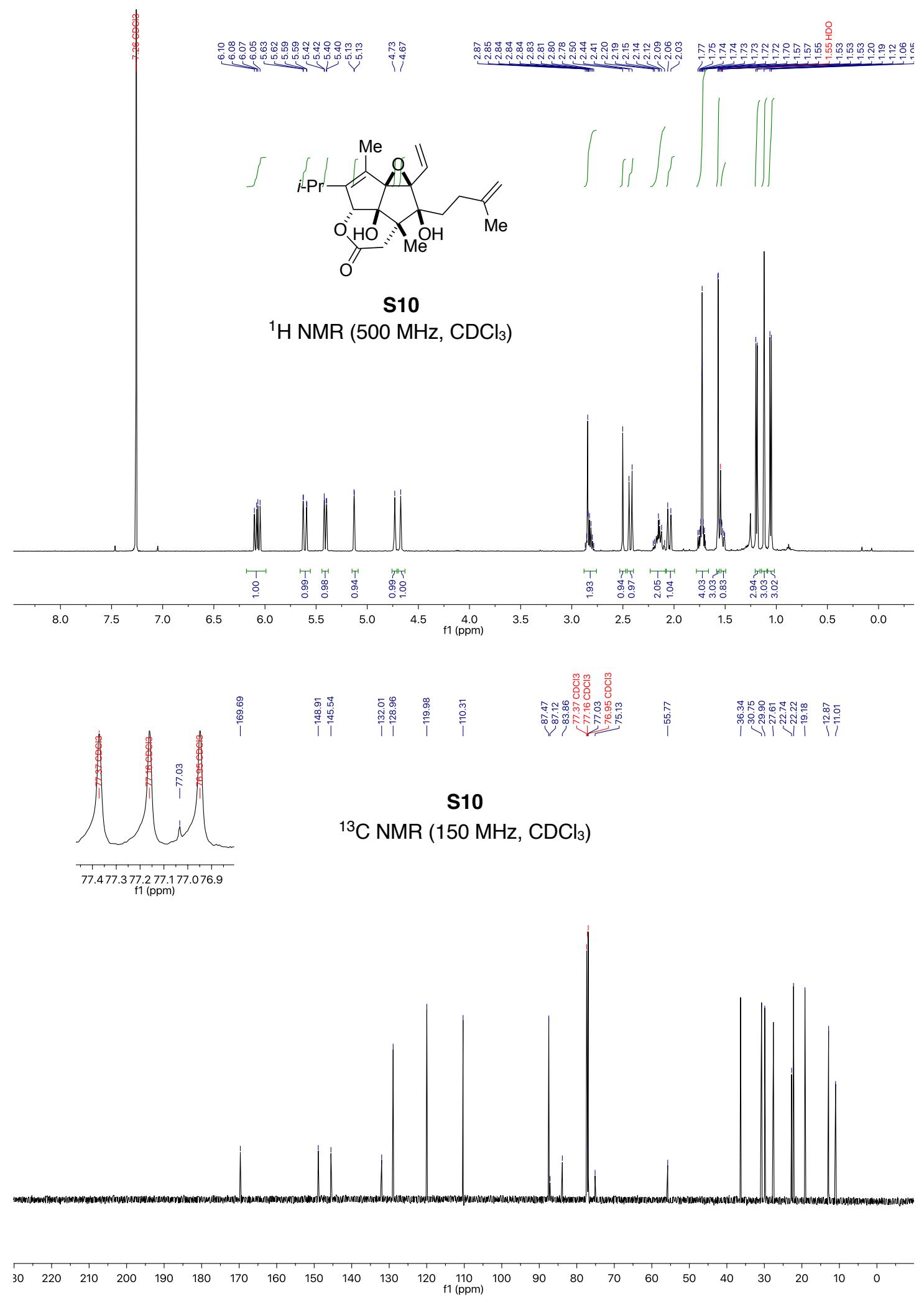

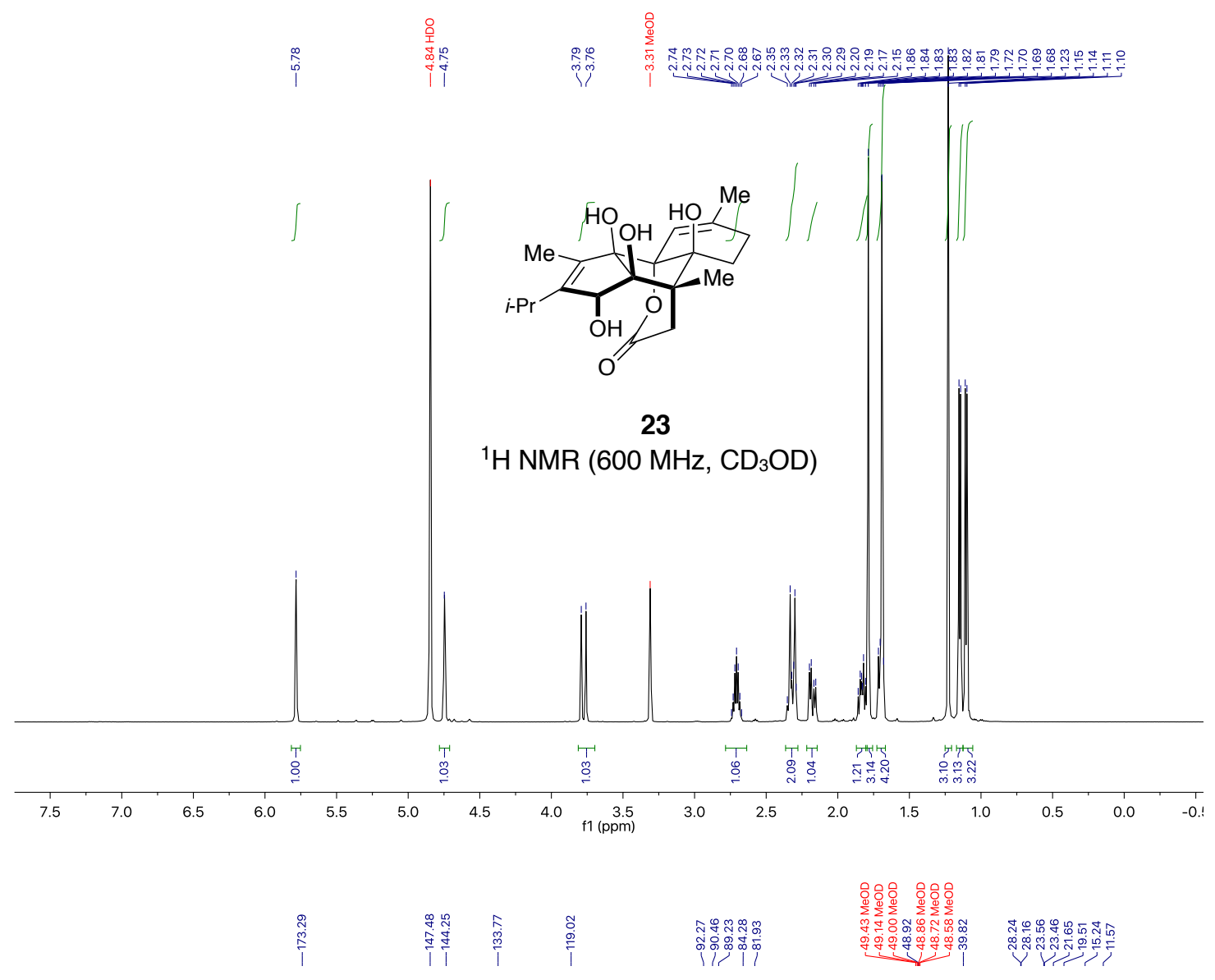

23

${ }^{13} \mathrm{C}$ NMR $\left(150 \mathrm{MHz}, \mathrm{CD}_{3} \mathrm{OD}\right)$

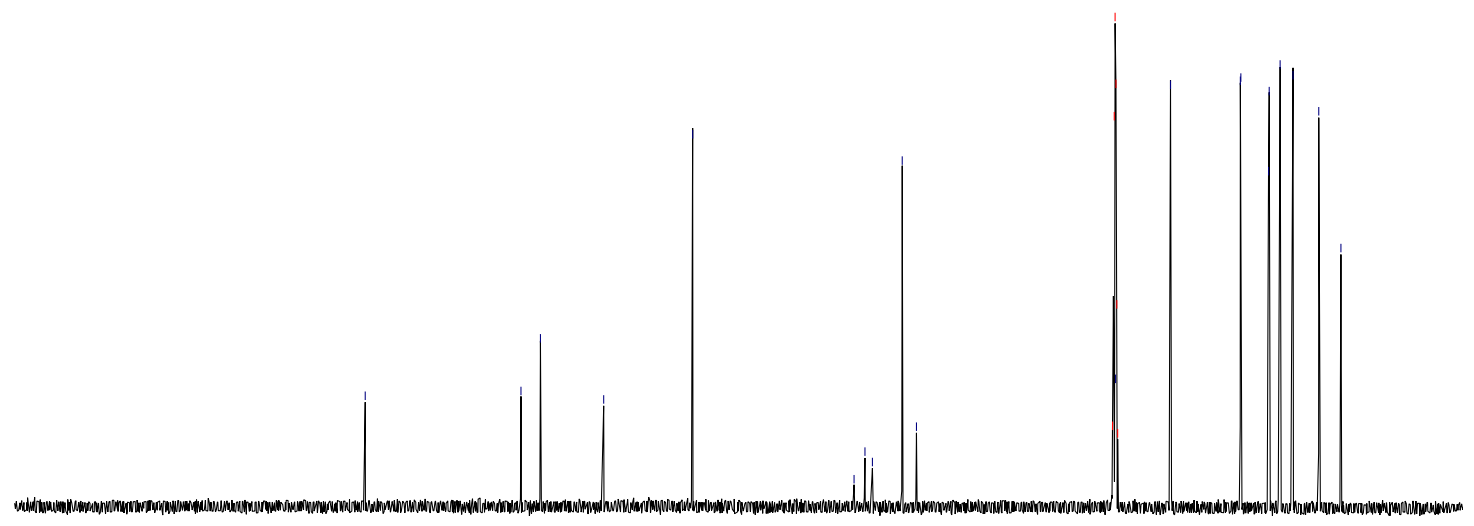

$\begin{array}{llllllllllllllllllllllllllll}30 & 220 & 210 & 200 & 190 & 180 & 170 & 160 & 150 & 140 & 130 & 120 & \begin{array}{l}110 \\ \mathrm{f}(\mathrm{ppm})\end{array} & 100 & 90 & 80 & 70 & 60 & 50 & 40 & 30 & 20 & 10 & 0 & 0\end{array}$ 


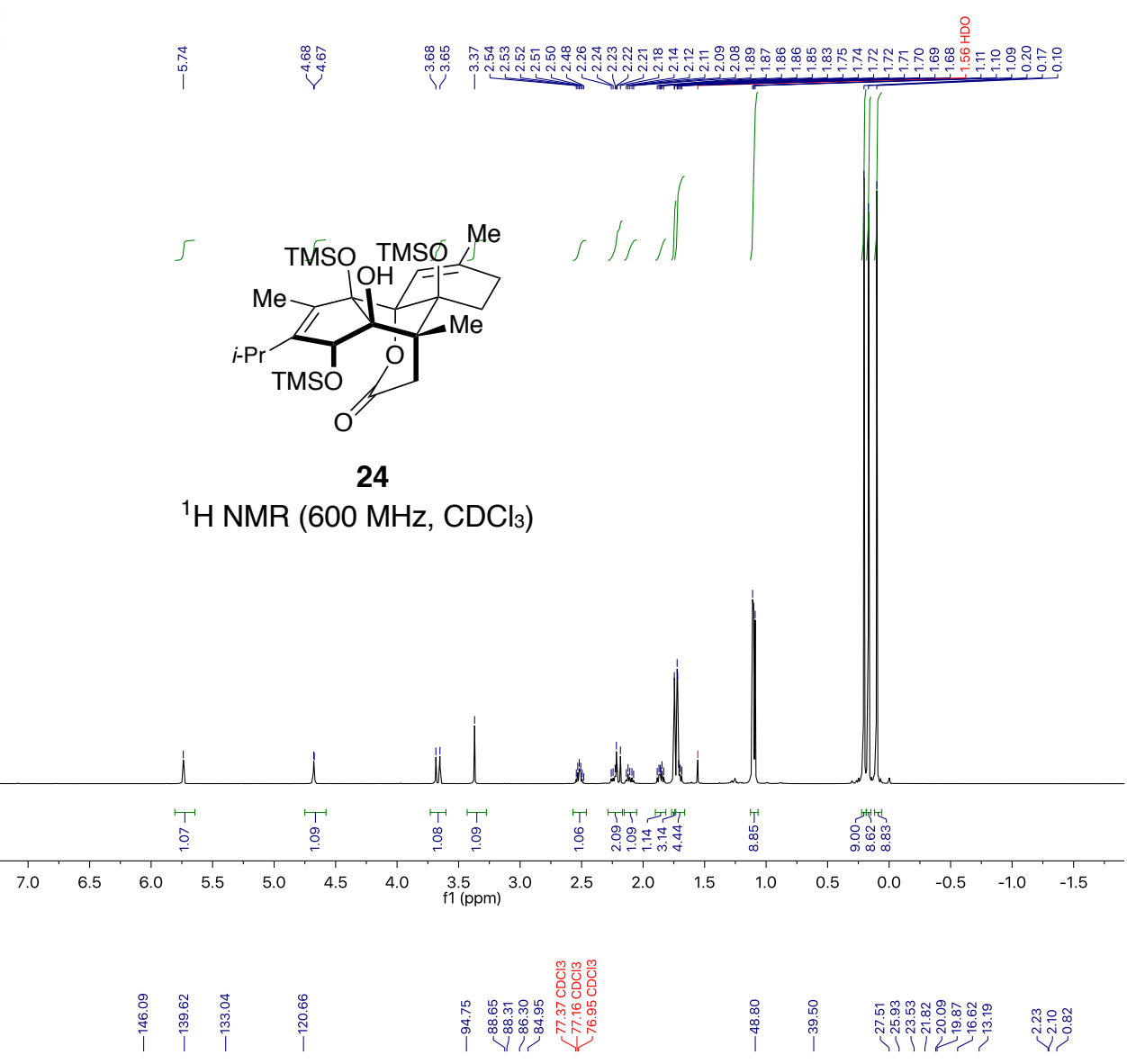

24

${ }^{13} \mathrm{C} \mathrm{NMR}\left(150 \mathrm{MHz}, \mathrm{CDCl}_{3}\right)$

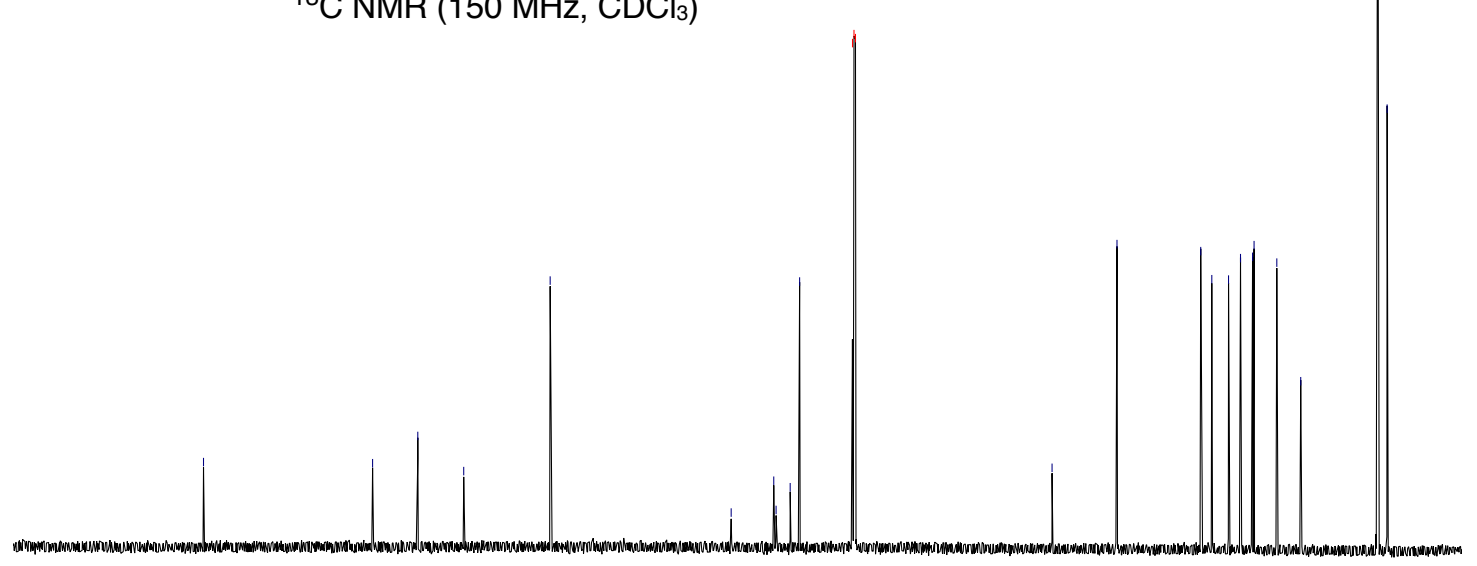

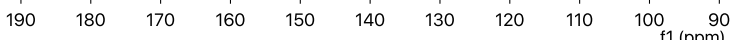




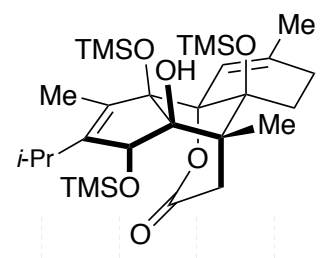

\section{Selected 1D nOe of $\mathbf{2 4}$ \\ (500 MHz, $\mathrm{CDCl}_{3}$ )}
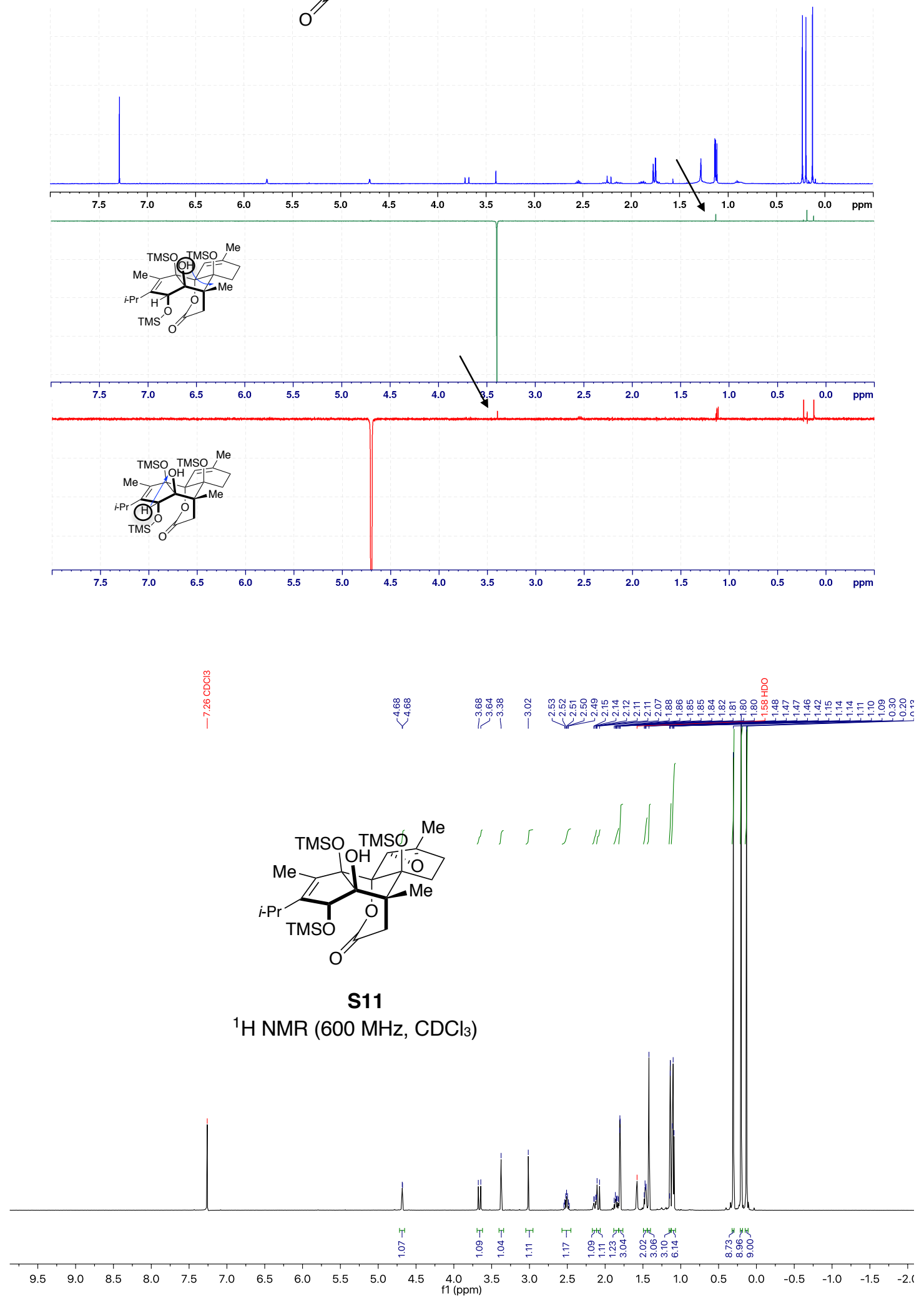

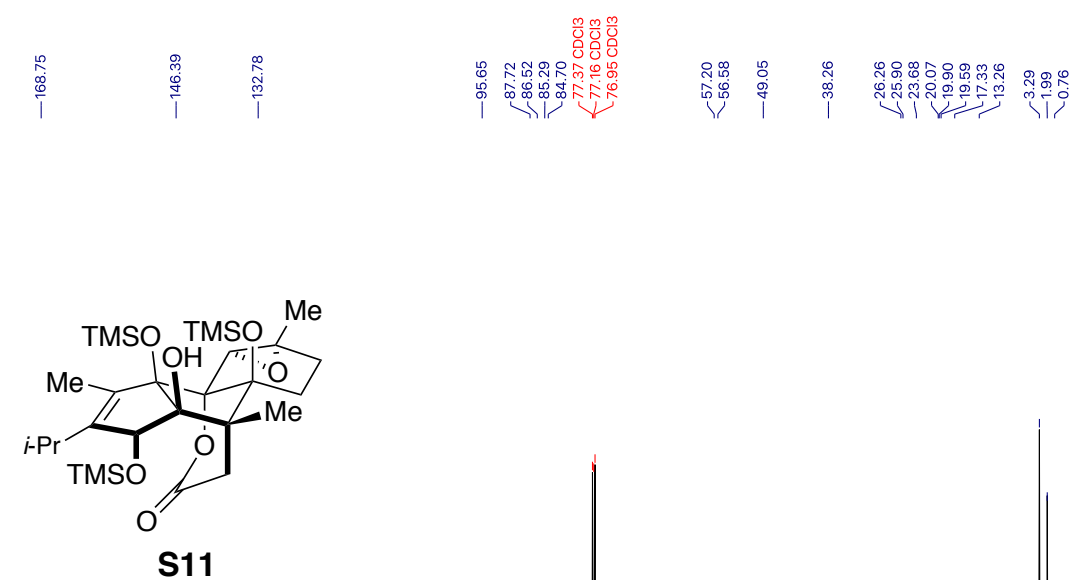

${ }^{13} \mathrm{C}$ NMR $\left(150 \mathrm{MHz}, \mathrm{CDCl}_{3}\right)$
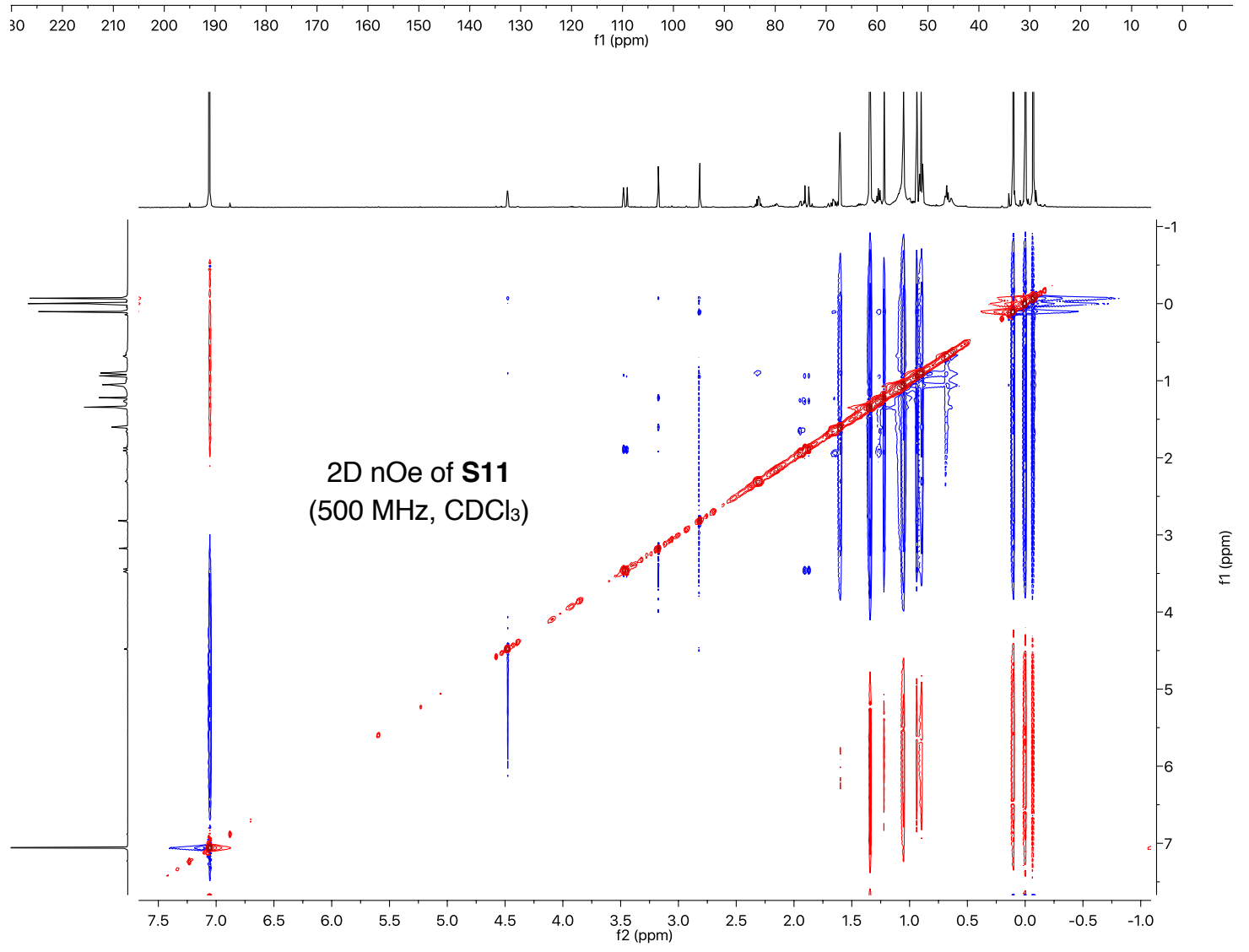


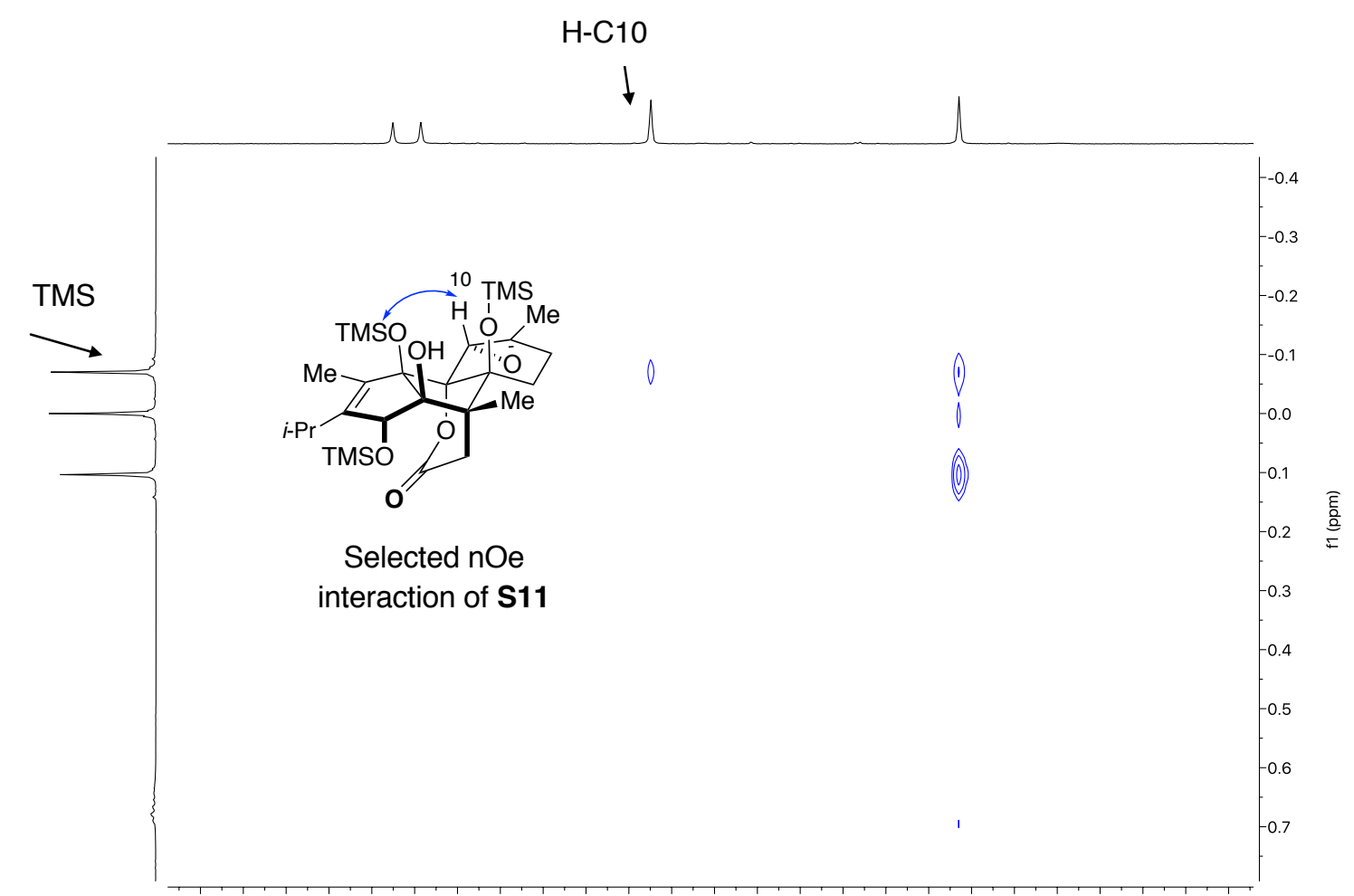

$\begin{array}{llllllllllllllllllllllllllllllllllll}3.70 & 3.65 & 3.60 & 3.55 & 3.50 & 3.45 & 3.40 & 3.35 & 3.30 & 3.25 & 3.20 & 3.15 & 3.10 & 3.05 & 3.00 & 2.95 & 2.90 & 2.85 & 2.80 & 2.75 & 2.70 & 2.65 & 2.60 & 2.55 & 2.50\end{array}$

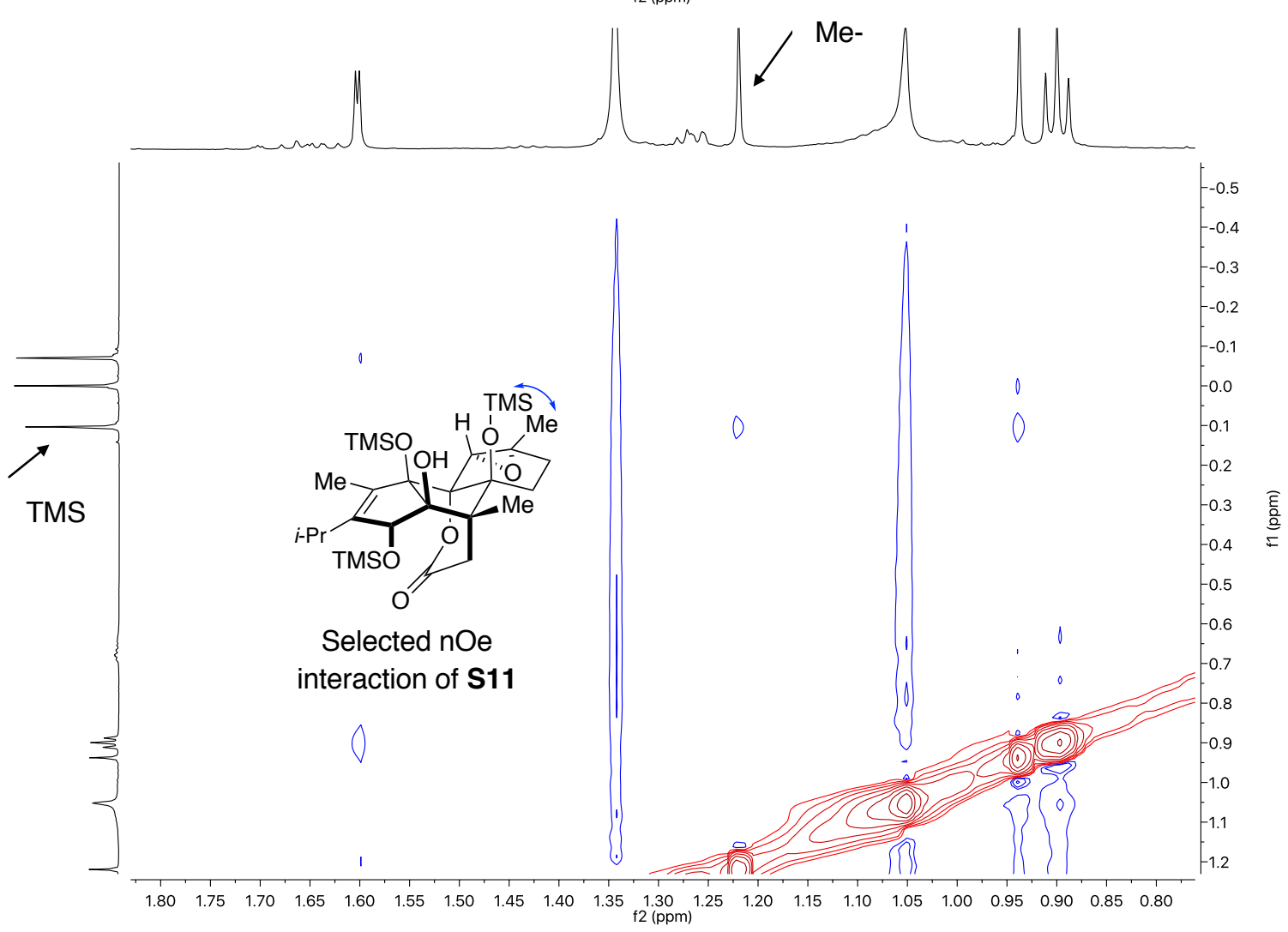




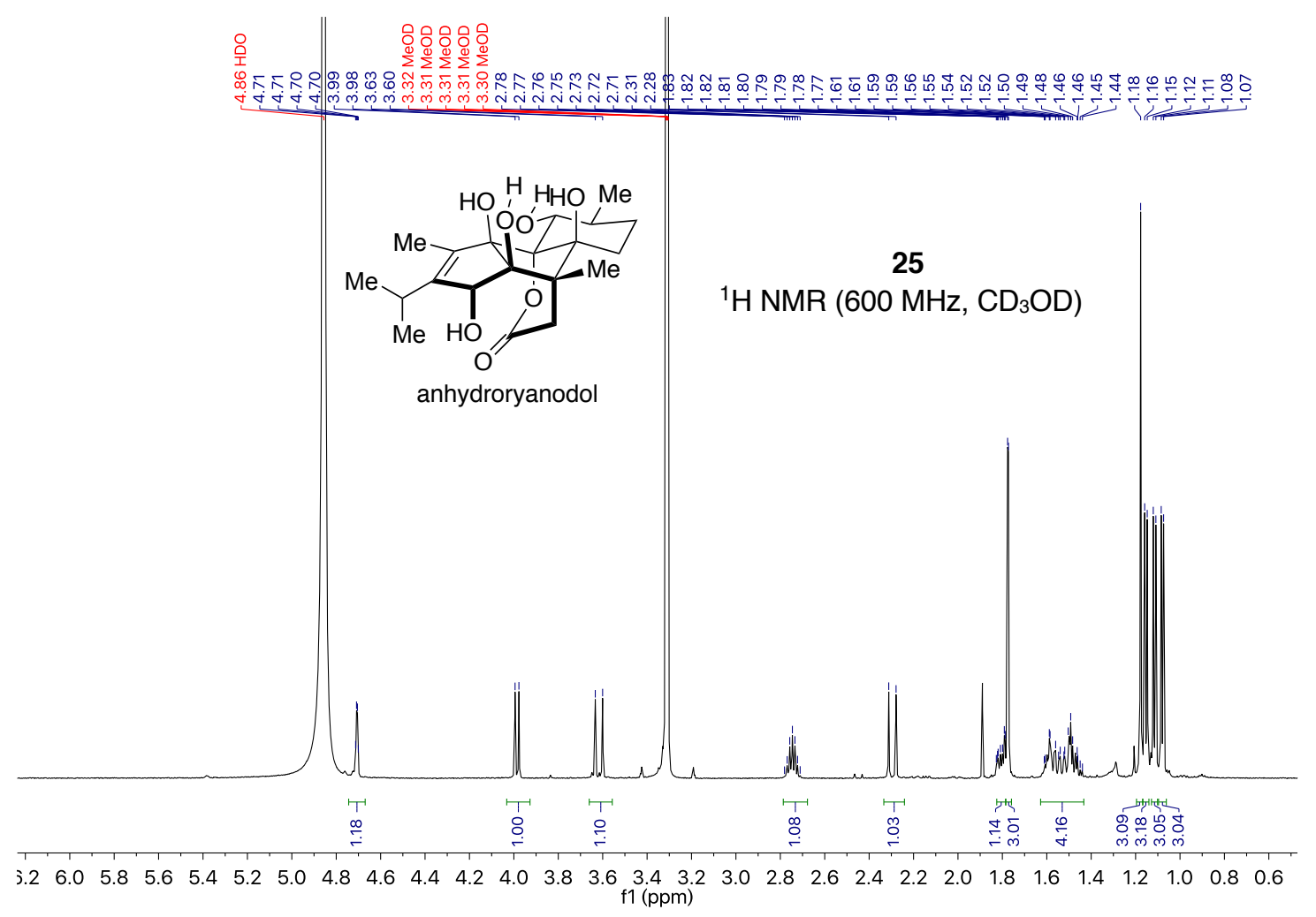

25

${ }^{13} \mathrm{C}$ NMR (150 MHz, $\left.\mathrm{CD}_{3} \mathrm{OD}\right)$

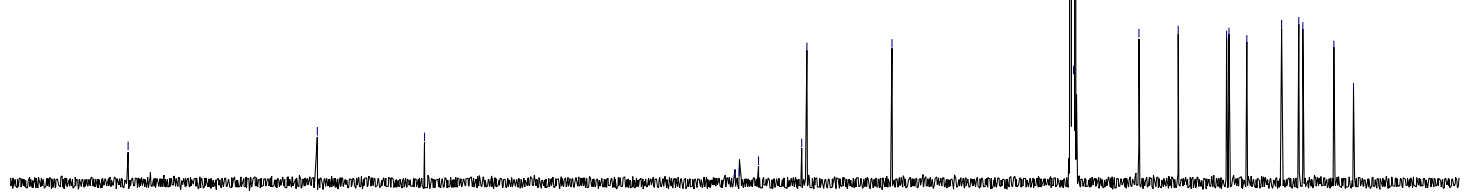

180
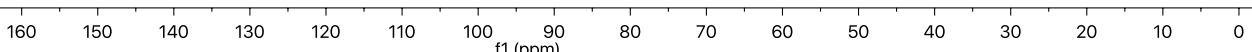


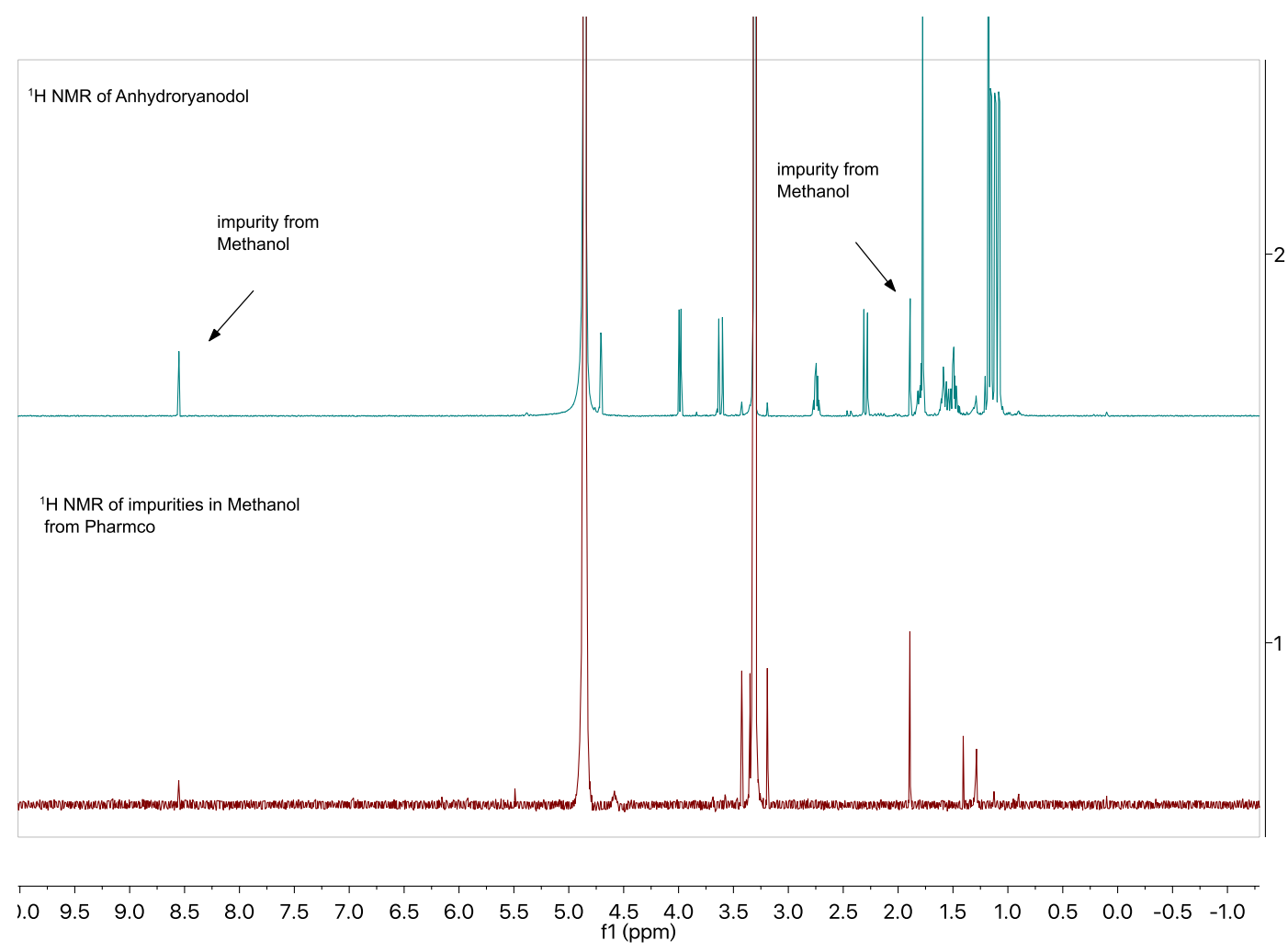


5. X-Ray Data of Compound 14 


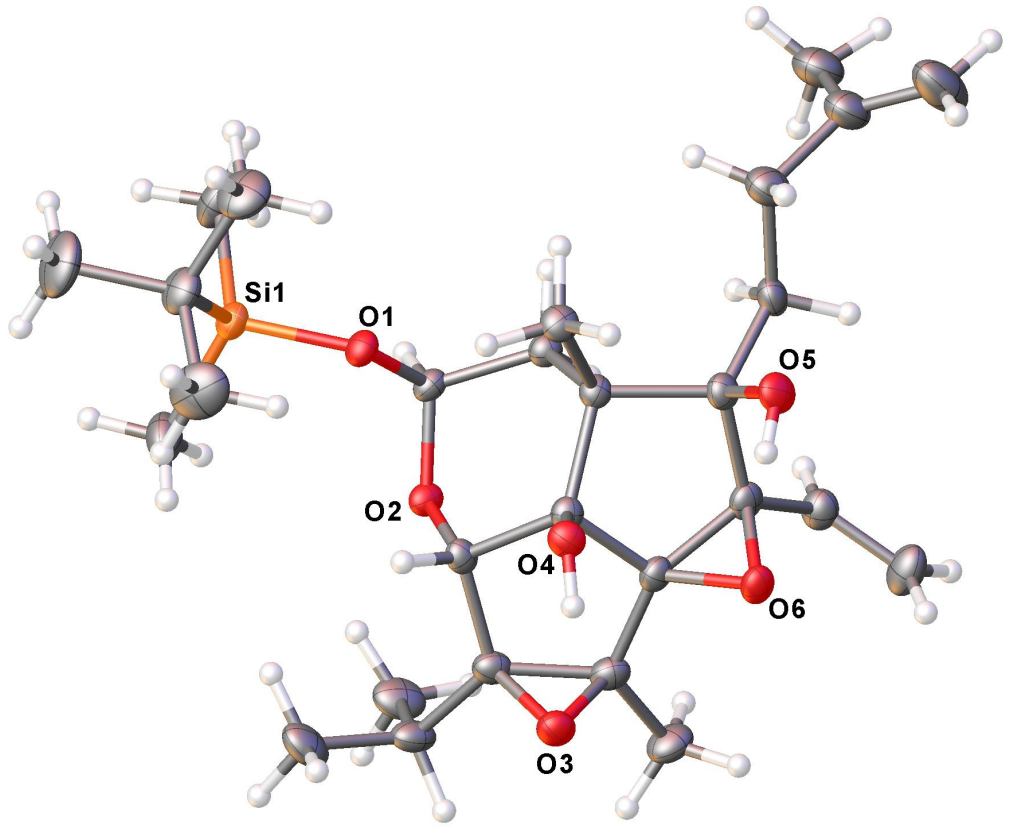

Table 1. Crystal data and structure refinement for micalizio22_0m_a.

Identification code

Empirical formula

Formula weight

Temperature

Wavelength

Crystal system

Space group

Unit cell dimensions

Volume

Z, Z'

Density (calculated)

Absorption coefficient

$\mathrm{F}(000)$

Crystal size

Theta range for data collection

Index ranges

Reflections collected

Independent reflections

Completeness to theta $=67.679^{\circ}$

Absorption correction

Max. and min. transmission

Refinement method

Data / restraints / parameters

Goodness-of-fit on $\mathrm{F}^{2}$

Final $\mathrm{R}$ indices [I $>2 \operatorname{sigma}(\mathrm{I})]$

$\mathrm{R}$ indices (all data)

Extinction coefficient

Largest diff. peak and hole kd-4-67

C28 H46 O6 Si

506.74

$100.0 \mathrm{~K}$

$1.54178 \AA$

Monoclinic

P 21/c

$\mathrm{a}=11.9235(12) \AA$

$\alpha=90^{\circ}$.

$\mathrm{b}=25.717(2) \AA$

$\mathrm{c}=20.0780(18) \AA$

$\beta=106.615(3)^{\circ}$.

$\gamma=90^{\circ}$.

$5899.5(10) \AA^{3}$

8,2

$1.141 \mathrm{Mg} / \mathrm{m}^{3}$

$0.996 \mathrm{~mm}^{-1}$

2208

$0.28 \times 0.18 \times 0.12 \mathrm{~mm}^{3}$

2.868 to $68.377^{\circ}$.

$-14<=\mathrm{h}<=14,-30<=\mathrm{k}<=30,-24<=1<=24$

58196

$10691[\mathrm{R}$ (int) $=0.0508]$

$99.1 \%$

Semi-empirical from equivalents

0.5849 and 0.5196

Full-matrix least-squares on $\mathrm{F}^{2}$

10691 / 0 / 655

1.041

$\mathrm{R} 1=0.0510, \mathrm{wR} 2=0.1245$

$\mathrm{R} 1=0.0633, \mathrm{wR} 2=0.1310$

$\mathrm{n} / \mathrm{a}$

0.568 and -0.353 e. $\AA^{-3}$ 
Table 2. Atomic coordinates $\left(\times 10^{4}\right)$ and equivalent isotropic displacement parameters $\left(\AA^{2} \times 10^{3}\right)$ for micalizio22_0m_a. U(eq) is defined as one third of the trace of the orthogonalized $U^{i j}$ tensor.

\begin{tabular}{|c|c|c|c|c|}
\hline & $\mathrm{x}$ & $\mathrm{y}$ & $\mathrm{z}$ & $\mathrm{U}(\mathrm{eq})$ \\
\hline $\operatorname{Si}(1)$ & $419(1)$ & $4504(1)$ & 1651(1) & $22(1)$ \\
\hline $\operatorname{Si}\left(1^{\prime}\right)$ & $6307(1)$ & $1317(1)$ & $3687(1)$ & $24(1)$ \\
\hline $\mathrm{O}\left(2^{\prime}\right)$ & $5854(1)$ & $2472(1)$ & $2779(1)$ & $20(1)$ \\
\hline $\mathrm{O}(2)$ & $621(1)$ & $3278(1)$ & $2298(1)$ & $19(1)$ \\
\hline $\mathrm{O}(1)$ & $265(1)$ & $4170(1)$ & $2330(1)$ & $20(1)$ \\
\hline $\mathrm{O}(6)$ & $-725(1)$ & 2499(1) & $3982(1)$ & $23(1)$ \\
\hline $\mathrm{O}\left(3^{\prime}\right)$ & $3317(1)$ & $3188(1)$ & 1771(1) & $25(1)$ \\
\hline $\mathrm{O}(3)$ & $-1443(1)$ & $2271(1)$ & $2412(1)$ & $25(1)$ \\
\hline $\mathrm{O}(4)$ & $-1930(1)$ & $3234(1)$ & $2982(1)$ & $22(1)$ \\
\hline $\mathrm{O}\left(4^{\prime}\right)$ & $3143(1)$ & $2920(1)$ & $3121(1)$ & $22(1)$ \\
\hline $\mathrm{O}(5)$ & $-666(1)$ & $3375(1)$ & $4616(1)$ & $26(1)$ \\
\hline $\mathrm{O}\left(1^{\prime}\right)$ & $5843(1)$ & $1928(1)$ & $3706(1)$ & $21(1)$ \\
\hline $\mathrm{O}\left(5^{\prime}\right)$ & $4169(1)$ & $3761(1)$ & $4302(1)$ & $31(1)$ \\
\hline $\mathrm{O}\left(6^{\prime}\right)$ & $3880(1)$ & $3964(1)$ & $3005(1)$ & $28(1)$ \\
\hline$C(6)$ & $-249(2)$ & $2653(1)$ & $3424(1)$ & $20(1)$ \\
\hline$C\left(20^{\prime}\right)$ & $6351(2)$ & $2834(1)$ & $3922(1)$ & $19(1)$ \\
\hline$C\left(6^{\prime}\right)$ & $4506(2)$ & $3532(1)$ & $2820(1)$ & $23(1)$ \\
\hline$C\left(4^{\prime}\right)$ & $4423(2)$ & 2904(1) & 1930(1) & $22(1)$ \\
\hline $\mathrm{C}(28)$ & $-246(2)$ & $2255(1)$ & $2888(1)$ & $24(1)$ \\
\hline$C(4)$ & $-492(2)$ & $2527(1)$ & $2214(1)$ & $22(1)$ \\
\hline $\mathrm{C}(21)$ & $1018(2)$ & $3758(1)$ & $2635(1)$ & $18(1)$ \\
\hline$C\left(21^{\prime}\right)$ & $6392(2)$ & $2357(1)$ & 3491(1) & $19(1)$ \\
\hline$C(17)$ & $-26(2)$ & $3601(1)$ & $3571(1)$ & $18(1)$ \\
\hline$C(20)$ & $1134(2)$ & $3706(1)$ & $3403(1)$ & $19(1)$ \\
\hline$C(8)$ & $1409(2)$ & $2421(1)$ & $4573(1)$ & $26(1)$ \\
\hline$C(19)$ & $-502(2)$ & $3117(1)$ & $2338(1)$ & $19(1)$ \\
\hline$C(10)$ & $283(2)$ & $3331(1)$ & $4315(1)$ & $21(1)$ \\
\hline$C(7)$ & $428(2)$ & $2742(1)$ & $4156(1)$ & $21(1)$ \\
\hline$C\left(19^{\prime}\right)$ & $4643(2)$ & $2607(1)$ & $2618(1)$ & $19(1)$ \\
\hline$C\left(7^{\prime}\right)$ & $5105(2)$ & $3894(1)$ & $3386(1)$ & $26(1)$ \\
\hline $\mathrm{C}(18)$ & $-710(2)$ & $3168(1)$ & $3067(1)$ & $18(1)$ \\
\hline
\end{tabular}




\begin{tabular}{|c|c|c|c|c|}
\hline $\mathrm{C}\left(28^{\prime}\right)$ & $4434(2)$ & $3469(1)$ & 2071(1) & $25(1)$ \\
\hline$C\left(16^{\prime}\right)$ & $4601(2)$ & 2691(1) & $4373(1)$ & $26(1)$ \\
\hline$C\left(8^{\prime}\right)$ & $5907(2)$ & $4314(1)$ & $3313(1)$ & $34(1)$ \\
\hline$C\left(10^{\prime}\right)$ & $5168(2)$ & $3614(1)$ & $4087(1)$ & $26(1)$ \\
\hline$C\left(17^{\prime}\right)$ & $5109(2)$ & $3016(1)$ & 3891(1) & $20(1)$ \\
\hline$C(16)$ & $-739(2)$ & 4099(1) & $3538(1)$ & $23(1)$ \\
\hline$C(11)$ & $1347(2)$ & $3536(1)$ & $4873(1)$ & $24(1)$ \\
\hline$C\left(18^{\prime}\right)$ & $4325(2)$ & $3003(1)$ & $3123(1)$ & $20(1)$ \\
\hline$C\left(11^{\prime}\right)$ & $6229(2)$ & $3754(1)$ & $4702(1)$ & $29(1)$ \\
\hline$C(24)$ & $-899(2)$ & 4939(1) & $1424(1)$ & $31(1)$ \\
\hline$C\left(2^{\prime}\right)$ & $4694(2)$ & $2667(1)$ & $1302(1)$ & $26(1)$ \\
\hline$C\left(24^{\prime}\right)$ & $5271(2)$ & $928(1)$ & $4042(1)$ & $35(1)$ \\
\hline$C\left(1^{\prime}\right)$ & $4230(2)$ & 2113(1) & $1183(1)$ & $32(1)$ \\
\hline$C(1)$ & $1045(2)$ & $2304(1)$ & $1607(1)$ & $36(1)$ \\
\hline$C(2)$ & $-252(2)$ & $2298(1)$ & $1572(1)$ & $28(1)$ \\
\hline $\mathrm{C}(9)$ & 1291(2) & 1998(1) & $4912(1)$ & $35(1)$ \\
\hline$C(13)$ & $2183(2)$ & $4172(1)$ & $5825(1)$ & $38(1)$ \\
\hline$C\left(12^{\prime}\right)$ & $6143(2)$ & $4282(1)$ & $5028(1)$ & $38(1)$ \\
\hline$C\left(5^{\prime}\right)$ & $4711(2)$ & $3892(1)$ & 1631(1) & $35(1)$ \\
\hline$C\left(23^{\prime}\right)$ & $7834(2)$ & $1267(1)$ & $4259(2)$ & $43(1)$ \\
\hline $\mathrm{C}(12)$ & $1251(2)$ & $4087(1)$ & $5143(1)$ & $33(1)$ \\
\hline $\mathrm{C}(23)$ & $1805(2)$ & $4883(1)$ & $1910(1)$ & $39(1)$ \\
\hline$C(5)$ & $308(2)$ & $1730(1)$ & $3053(1)$ & $32(1)$ \\
\hline$C(3)$ & $-993(2)$ & $2559(1)$ & $913(1)$ & $36(1)$ \\
\hline$C\left(13^{\prime}\right)$ & $7188(2)$ & $4444(1)$ & $5614(1)$ & $41(1)$ \\
\hline$C\left(3^{\prime}\right)$ & $6001(2)$ & 2692(1) & $1350(1)$ & $36(1)$ \\
\hline$C(15)$ & $3395(2)$ & $4239(1)$ & $5782(1)$ & $42(1)$ \\
\hline $\mathrm{C}(22)$ & $484(3)$ & $4054(1)$ & $941(1)$ & $39(1)$ \\
\hline$C\left(27^{\prime}\right)$ & $5331(3)$ & $1107(1)$ & $4781(2)$ & $48(1)$ \\
\hline $\mathrm{C}\left(9^{\prime}\right)$ & $5572(2)$ & $4759(1)$ & $3000(2)$ & $42(1)$ \\
\hline $\mathrm{C}(27)$ & $-874(2)$ & $5290(1)$ & $2049(2)$ & $42(1)$ \\
\hline$C\left(15^{\prime}\right)$ & $6967(3)$ & 4894(1) & $6020(2)$ & $49(1)$ \\
\hline$C\left(22^{\prime}\right)$ & $6226(3)$ & $1133(1)$ & 2781(1) & $47(1)$ \\
\hline$C(14)$ & 1932(3) & 4161(1) & $6426(2)$ & $58(1)$ \\
\hline$C\left(26^{\prime}\right)$ & $5588(3)$ & $344(1)$ & $4062(2)$ & $54(1)$ \\
\hline$C(25)$ & $-2015(2)$ & $4600(1)$ & $1247(2)$ & $49(1)$ \\
\hline
\end{tabular}


C(26)

$\mathrm{C}\left(25^{\prime}\right)$

C(14')
$-903(3)$

4014(3)

8225(3)
5278(1)

1013(1)

4218(2)
790(2)

3578(2)

5766(2)
51(1)

66(1)

84(1) 
Table 3. Bond lengths $[\AA]$ and angles $\left[{ }^{\circ}\right]$ for micalizio22_0m_a.

\begin{tabular}{|c|c|}
\hline $\mathrm{Si}(1)-\mathrm{O}(1)$ & $1.6661(14)$ \\
\hline $\mathrm{Si}(1)-\mathrm{C}(24)$ & $1.878(2)$ \\
\hline $\operatorname{Si}(1)-C(23)$ & $1.860(2)$ \\
\hline $\mathrm{Si}(1)-\mathrm{C}(22)$ & $1.855(3)$ \\
\hline $\mathrm{Si}\left(1^{\prime}\right)-\mathrm{O}\left(1^{\prime}\right)$ & $1.6680(15)$ \\
\hline $\operatorname{Si}\left(1^{\prime}\right)-C\left(24^{\prime}\right)$ & $1.882(2)$ \\
\hline $\mathrm{Si}\left(1^{\prime}\right)-\mathrm{C}\left(23^{\prime}\right)$ & $1.858(3)$ \\
\hline $\operatorname{Si}\left(1^{\prime}\right)-C\left(22^{\prime}\right)$ & $1.856(3)$ \\
\hline $\mathrm{O}\left(2^{\prime}\right)-\mathrm{C}\left(21^{\prime}\right)$ & $1.421(2)$ \\
\hline $\mathrm{O}\left(2^{\prime}\right)-\mathrm{C}\left(19^{\prime}\right)$ & $1.430(2)$ \\
\hline $\mathrm{O}(2)-\mathrm{C}(21)$ & $1.422(2)$ \\
\hline $\mathrm{O}(2)-\mathrm{C}(19)$ & $1.426(2)$ \\
\hline $\mathrm{O}(1)-\mathrm{C}(21)$ & $1.410(2)$ \\
\hline $\mathrm{O}(6)-\mathrm{C}(6)$ & $1.449(2)$ \\
\hline $\mathrm{O}(6)-\mathrm{C}(7)$ & $1.459(2)$ \\
\hline $\mathrm{O}\left(3^{\prime}\right)-\mathrm{C}\left(4^{\prime}\right)$ & $1.459(2)$ \\
\hline $\mathrm{O}\left(3^{\prime}\right)-\mathrm{C}\left(28^{\prime}\right)$ & $1.482(3)$ \\
\hline $\mathrm{O}(3)-\mathrm{C}(28)$ & $1.473(3)$ \\
\hline $\mathrm{O}(3)-\mathrm{C}(4)$ & $1.460(2)$ \\
\hline $\mathrm{O}(4)-\mathrm{H}(4)$ & 0.8400 \\
\hline $\mathrm{O}(4)-\mathrm{C}(18)$ & $1.425(2)$ \\
\hline $\mathrm{O}\left(4^{\prime}\right)-\mathrm{H}\left(4^{\prime}\right)$ & 0.8400 \\
\hline $\mathrm{O}\left(4^{\prime}\right)-\mathrm{C}\left(18^{\prime}\right)$ & $1.424(2)$ \\
\hline $\mathrm{O}(5)-\mathrm{H}(5)$ & 0.8400 \\
\hline $\mathrm{O}(5)-\mathrm{C}(10)$ & $1.431(2)$ \\
\hline $\mathrm{O}\left(1^{\prime}\right)-\mathrm{C}\left(21^{\prime}\right)$ & $1.412(2)$ \\
\hline $\mathrm{O}\left(5^{\prime}\right)-\mathrm{H}\left(5^{\prime}\right)$ & 0.8400 \\
\hline $\mathrm{O}\left(5^{\prime}\right)-\mathrm{C}\left(10^{\prime}\right)$ & $1.429(2)$ \\
\hline $\mathrm{O}\left(6^{\prime}\right)-\mathrm{C}\left(6^{\prime}\right)$ & $1.445(2)$ \\
\hline $\mathrm{O}\left(6^{\prime}\right)-\mathrm{C}\left(7^{\prime}\right)$ & $1.453(3)$ \\
\hline $\mathrm{C}(6)-\mathrm{C}(28)$ & $1.486(3)$ \\
\hline$C(6)-C(7)$ & $1.478(3)$ \\
\hline$C(6)-C(18)$ & $1.531(3)$ \\
\hline $\mathrm{C}\left(20^{\prime}\right)-\mathrm{H}(20 \mathrm{C})$ & 0.9900 \\
\hline
\end{tabular}




\begin{tabular}{|c|c|}
\hline $\mathrm{C}\left(20^{\prime}\right)-\mathrm{H}(20 \mathrm{D})$ & 0.9900 \\
\hline$C\left(20^{\prime}\right)-C\left(21^{\prime}\right)$ & $1.510(3)$ \\
\hline $\mathrm{C}\left(20^{\prime}\right)-\mathrm{C}\left(17^{\prime}\right)$ & $1.537(3)$ \\
\hline$C\left(6^{\prime}\right)-C\left(7^{\prime}\right)$ & $1.485(3)$ \\
\hline $\mathrm{C}\left(6^{\prime}\right)-\mathrm{C}\left(28^{\prime}\right)$ & $1.491(3)$ \\
\hline $\mathrm{C}\left(6^{\prime}\right)-\mathrm{C}\left(18^{\prime}\right)$ & $1.529(3)$ \\
\hline $\mathrm{C}\left(4^{\prime}\right)-\mathrm{C}\left(19^{\prime}\right)$ & $1.535(3)$ \\
\hline$C\left(4^{\prime}\right)-C\left(28^{\prime}\right)$ & $1.477(3)$ \\
\hline$C\left(4^{\prime}\right)-C\left(2^{\prime}\right)$ & $1.517(3)$ \\
\hline$C(28)-C(4)$ & $1.474(3)$ \\
\hline$C(28)-C(5)$ & $1.499(3)$ \\
\hline$C(4)-C(19)$ & $1.539(3)$ \\
\hline $\mathrm{C}(4)-\mathrm{C}(2)$ & $1.517(3)$ \\
\hline $\mathrm{C}(21)-\mathrm{H}(21)$ & 1.0000 \\
\hline$C(21)-C(20)$ & $1.514(3)$ \\
\hline $\mathrm{C}\left(21^{\prime}\right)-\mathrm{H}\left(21^{\prime}\right)$ & 1.0000 \\
\hline$C(17)-C(20)$ & $1.539(3)$ \\
\hline$C(17)-C(10)$ & $1.592(3)$ \\
\hline$C(17)-C(18)$ & $1.567(3)$ \\
\hline$C(17)-C(16)$ & $1.529(3)$ \\
\hline $\mathrm{C}(20)-\mathrm{H}(20 \mathrm{~A})$ & 0.9900 \\
\hline $\mathrm{C}(20)-\mathrm{H}(20 \mathrm{~B})$ & 0.9900 \\
\hline $\mathrm{C}(8)-\mathrm{H}(8)$ & 0.9500 \\
\hline $\mathrm{C}(8)-\mathrm{C}(7)$ & $1.481(3)$ \\
\hline C(8)-C(9) & $1.313(3)$ \\
\hline C(19)-H(19) & 1.0000 \\
\hline C(19)-C(18) & $1.558(3)$ \\
\hline $\mathrm{C}(10)-\mathrm{C}(7)$ & $1.566(3)$ \\
\hline $\mathrm{C}(10)-\mathrm{C}(11)$ & $1.526(3)$ \\
\hline $\mathrm{C}\left(19^{\prime}\right)-\mathrm{H}\left(19^{\prime}\right)$ & 1.0000 \\
\hline$C\left(19^{\prime}\right)-C\left(18^{\prime}\right)$ & $1.558(3)$ \\
\hline$C\left(7^{\prime}\right)-C\left(8^{\prime}\right)$ & $1.477(3)$ \\
\hline $\mathrm{C}\left(7^{\prime}\right)-\mathrm{C}\left(10^{\prime}\right)$ & $1.564(3)$ \\
\hline$C\left(28^{\prime}\right)-C\left(5^{\prime}\right)$ & $1.496(3)$ \\
\hline $\mathrm{C}\left(16^{\prime}\right)-\mathrm{H}(16 \mathrm{D})$ & 0.9800 \\
\hline$C\left(16^{\prime}\right)-\mathrm{H}(16 \mathrm{E})$ & 0.9800 \\
\hline
\end{tabular}




\begin{tabular}{|c|c|}
\hline $\mathrm{C}\left(16^{\prime}\right)-\mathrm{H}(16 \mathrm{~F})$ & 0.9800 \\
\hline$C\left(16^{\prime}\right)-C\left(17^{\prime}\right)$ & $1.528(3)$ \\
\hline $\mathrm{C}\left(8^{\prime}\right)-\mathrm{H}\left(8^{\prime}\right)$ & 0.9500 \\
\hline $\mathrm{C}\left(8^{\prime}\right)-\mathrm{C}\left(9^{\prime}\right)$ & $1.312(4)$ \\
\hline$C\left(10^{\prime}\right)-C\left(17^{\prime}\right)$ & $1.584(3)$ \\
\hline$C\left(10^{\prime}\right)-C\left(11^{\prime}\right)$ & $1.538(3)$ \\
\hline$C\left(17^{\prime}\right)-C\left(18^{\prime}\right)$ & $1.559(3)$ \\
\hline $\mathrm{C}(16)-\mathrm{H}(16 \mathrm{~A})$ & 0.9800 \\
\hline $\mathrm{C}(16)-\mathrm{H}(16 \mathrm{~B})$ & 0.9800 \\
\hline $\mathrm{C}(16)-\mathrm{H}(16 \mathrm{C})$ & 0.9800 \\
\hline $\mathrm{C}(11)-\mathrm{H}(11 \mathrm{~A})$ & 0.9900 \\
\hline $\mathrm{C}(11)-\mathrm{H}(11 \mathrm{~B})$ & 0.9900 \\
\hline$C(11)-C(12)$ & $1.532(3)$ \\
\hline $\mathrm{C}\left(11^{\prime}\right)-\mathrm{H}(11 \mathrm{C})$ & 0.9900 \\
\hline $\mathrm{C}\left(11^{\prime}\right)-\mathrm{H}(11 \mathrm{D})$ & 0.9900 \\
\hline $\mathrm{C}\left(11^{\prime}\right)-\mathrm{C}\left(12^{\prime}\right)$ & $1.523(3)$ \\
\hline$C(24)-C(27)$ & $1.538(4)$ \\
\hline$C(24)-C(25)$ & $1.545(4)$ \\
\hline$C(24)-C(26)$ & $1.542(3)$ \\
\hline $\mathrm{C}\left(2^{\prime}\right)-\mathrm{H}\left(2^{\prime}\right)$ & 1.0000 \\
\hline$C\left(2^{\prime}\right)-C\left(1^{\prime}\right)$ & $1.522(3)$ \\
\hline $\mathrm{C}\left(2^{\prime}\right)-\mathrm{C}\left(3^{\prime}\right)$ & $1.535(3)$ \\
\hline$C\left(24^{\prime}\right)-C\left(27^{\prime}\right)$ & $1.535(4)$ \\
\hline$C\left(24^{\prime}\right)-C\left(26^{\prime}\right)$ & $1.546(4)$ \\
\hline$C\left(24^{\prime}\right)-C\left(25^{\prime}\right)$ & $1.537(4)$ \\
\hline $\mathrm{C}\left(1^{\prime}\right)-\mathrm{H}\left(1^{\prime} \mathrm{A}\right)$ & 0.9800 \\
\hline C(1')-H(1'B) & 0.9800 \\
\hline $\mathrm{C}\left(1^{\prime}\right)-\mathrm{H}\left(1^{\prime} \mathrm{C}\right)$ & 0.9800 \\
\hline $\mathrm{C}(1)-\mathrm{H}(1 \mathrm{~A})$ & 0.9800 \\
\hline $\mathrm{C}(1)-\mathrm{H}(1 \mathrm{~B})$ & 0.9800 \\
\hline $\mathrm{C}(1)-\mathrm{H}(1 \mathrm{C})$ & 0.9800 \\
\hline $\mathrm{C}(1)-\mathrm{C}(2)$ & $1.529(3)$ \\
\hline $\mathrm{C}(2)-\mathrm{H}(2)$ & 1.0000 \\
\hline $\mathrm{C}(2)-\mathrm{C}(3)$ & $1.521(4)$ \\
\hline $\mathrm{C}(9)-\mathrm{H}(9 \mathrm{~A})$ & 0.9500 \\
\hline $\mathrm{C}(9)-\mathrm{H}(9 \mathrm{~B})$ & 0.9500 \\
\hline
\end{tabular}




\begin{tabular}{|c|c|}
\hline$C(13)-C(12)$ & $1.512(3)$ \\
\hline$C(13)-C(15)$ & $1.483(4)$ \\
\hline$C(13)-C(14)$ & $1.324(4)$ \\
\hline $\mathrm{C}\left(12^{\prime}\right)-\mathrm{H}(12 \mathrm{C})$ & 0.9900 \\
\hline $\mathrm{C}\left(12^{\prime}\right)-\mathrm{H}(12 \mathrm{D})$ & 0.9900 \\
\hline$C\left(12^{\prime}\right)-C\left(13^{\prime}\right)$ & $1.507(3)$ \\
\hline $\mathrm{C}\left(5^{\prime}\right)-\mathrm{H}\left(5^{\prime} \mathrm{A}\right)$ & 0.9800 \\
\hline $\mathrm{C}\left(5^{\prime}\right)-\mathrm{H}\left(5^{\prime} \mathrm{B}\right)$ & 0.9800 \\
\hline $\mathrm{C}\left(5^{\prime}\right)-\mathrm{H}\left(5^{\prime} \mathrm{C}\right)$ & 0.9800 \\
\hline $\mathrm{C}\left(23^{\prime}\right)-\mathrm{H}(23 \mathrm{D})$ & 0.9800 \\
\hline $\mathrm{C}\left(23^{\prime}\right)-\mathrm{H}(23 \mathrm{E})$ & 0.9800 \\
\hline $\mathrm{C}\left(23^{\prime}\right)-\mathrm{H}(23 \mathrm{~F})$ & 0.9800 \\
\hline $\mathrm{C}(12)-\mathrm{H}(12 \mathrm{~A})$ & 0.9900 \\
\hline $\mathrm{C}(12)-\mathrm{H}(12 \mathrm{~B})$ & 0.9900 \\
\hline $\mathrm{C}(23)-\mathrm{H}(23 \mathrm{~A})$ & 0.9800 \\
\hline $\mathrm{C}(23)-\mathrm{H}(23 \mathrm{~B})$ & 0.9800 \\
\hline $\mathrm{C}(23)-\mathrm{H}(23 \mathrm{C})$ & 0.9800 \\
\hline $\mathrm{C}(5)-\mathrm{H}(5 \mathrm{~A})$ & 0.9800 \\
\hline $\mathrm{C}(5)-\mathrm{H}(5 \mathrm{~B})$ & 0.9800 \\
\hline $\mathrm{C}(5)-\mathrm{H}(5 \mathrm{C})$ & 0.9800 \\
\hline $\mathrm{C}(3)-\mathrm{H}(3 \mathrm{~A})$ & 0.9800 \\
\hline $\mathrm{C}(3)-\mathrm{H}(3 \mathrm{~B})$ & 0.9800 \\
\hline $\mathrm{C}(3)-\mathrm{H}(3 \mathrm{C})$ & 0.9800 \\
\hline$C\left(13^{\prime}\right)-C\left(15^{\prime}\right)$ & $1.481(4)$ \\
\hline $\mathrm{C}\left(13^{\prime}\right)-\mathrm{C}\left(14^{\prime}\right)$ & $1.321(4)$ \\
\hline $\mathrm{C}\left(3^{\prime}\right)-\mathrm{H}\left(3^{\prime} \mathrm{A}\right)$ & 0.9800 \\
\hline $\mathrm{C}\left(3^{\prime}\right)-\mathrm{H}\left(3^{\prime} \mathrm{B}\right)$ & 0.9800 \\
\hline $\mathrm{C}\left(3^{\prime}\right)-\mathrm{H}\left(3^{\prime} \mathrm{C}\right)$ & 0.9800 \\
\hline $\mathrm{C}(15)-\mathrm{H}(15 \mathrm{~A})$ & 0.9800 \\
\hline $\mathrm{C}(15)-\mathrm{H}(15 \mathrm{~B})$ & 0.9800 \\
\hline C(15)-H(15C) & 0.9800 \\
\hline $\mathrm{C}(22)-\mathrm{H}(22 \mathrm{~A})$ & 0.9800 \\
\hline $\mathrm{C}(22)-\mathrm{H}(22 \mathrm{~B})$ & 0.9800 \\
\hline $\mathrm{C}(22)-\mathrm{H}(22 \mathrm{C})$ & 0.9800 \\
\hline $\mathrm{C}\left(27^{\prime}\right)-\mathrm{H}(27 \mathrm{D})$ & 0.9800 \\
\hline $\mathrm{C}\left(27^{\prime}\right)-\mathrm{H}(27 \mathrm{E})$ & 0.9800 \\
\hline
\end{tabular}




\begin{tabular}{|c|c|}
\hline $\mathrm{C}\left(27^{\prime}\right)-\mathrm{H}(27 \mathrm{~F})$ & 0.9800 \\
\hline $\mathrm{C}\left(9^{\prime}\right)-\mathrm{H}\left(9^{\prime} \mathrm{A}\right)$ & 0.9500 \\
\hline $\mathrm{C}\left(9^{\prime}\right)-\mathrm{H}\left(9^{\prime} \mathrm{B}\right)$ & 0.9500 \\
\hline $\mathrm{C}(27)-\mathrm{H}(27 \mathrm{~A})$ & 0.9800 \\
\hline $\mathrm{C}(27)-\mathrm{H}(27 \mathrm{~B})$ & 0.9800 \\
\hline $\mathrm{C}(27)-\mathrm{H}(27 \mathrm{C})$ & 0.9800 \\
\hline $\mathrm{C}\left(15^{\prime}\right)-\mathrm{H}(15 \mathrm{D})$ & 0.9800 \\
\hline$C\left(15^{\prime}\right)-\mathrm{H}(15 \mathrm{E})$ & 0.9800 \\
\hline $\mathrm{C}\left(15^{\prime}\right)-\mathrm{H}(15 \mathrm{~F})$ & 0.9800 \\
\hline $\mathrm{C}\left(22^{\prime}\right)-\mathrm{H}(22 \mathrm{D})$ & 0.9800 \\
\hline $\mathrm{C}\left(22^{\prime}\right)-\mathrm{H}(22 \mathrm{E})$ & 0.9800 \\
\hline $\mathrm{C}\left(22^{\prime}\right)-\mathrm{H}(22 \mathrm{~F})$ & 0.9800 \\
\hline $\mathrm{C}(14)-\mathrm{H}(14 \mathrm{~A})$ & 0.9500 \\
\hline $\mathrm{C}(14)-\mathrm{H}(14 \mathrm{~B})$ & 0.9500 \\
\hline$C\left(26^{\prime}\right)-H(26 D)$ & 0.9800 \\
\hline $\mathrm{C}\left(26^{\prime}\right)-\mathrm{H}(26 \mathrm{E})$ & 0.9800 \\
\hline $\mathrm{C}\left(26^{\prime}\right)-\mathrm{H}(26 \mathrm{~F})$ & 0.9800 \\
\hline $\mathrm{C}(25)-\mathrm{H}(25 \mathrm{~A})$ & 0.9800 \\
\hline $\mathrm{C}(25)-\mathrm{H}(25 \mathrm{~B})$ & 0.9800 \\
\hline $\mathrm{C}(25)-\mathrm{H}(25 \mathrm{C})$ & 0.9800 \\
\hline $\mathrm{C}(26)-\mathrm{H}(26 \mathrm{~A})$ & 0.9800 \\
\hline $\mathrm{C}(26)-\mathrm{H}(26 \mathrm{~B})$ & 0.9800 \\
\hline $\mathrm{C}(26)-\mathrm{H}(26 \mathrm{C})$ & 0.9800 \\
\hline $\mathrm{C}\left(25^{\prime}\right)-\mathrm{H}(25 \mathrm{D})$ & 0.9800 \\
\hline $\mathrm{C}\left(25^{\prime}\right)-\mathrm{H}(25 \mathrm{E})$ & 0.9800 \\
\hline $\mathrm{C}\left(25^{\prime}\right)-\mathrm{H}(25 \mathrm{~F})$ & 0.9800 \\
\hline $\mathrm{C}\left(14^{\prime}\right)-\mathrm{H}(14 \mathrm{C})$ & 0.9500 \\
\hline $\mathrm{C}\left(14^{\prime}\right)-\mathrm{H}(14 \mathrm{D})$ & 0.9500 \\
\hline $\mathrm{O}(1)-\mathrm{Si}(1)-\mathrm{C}(24)$ & $103.01(9)$ \\
\hline $\mathrm{O}(1)-\mathrm{Si}(1)-\mathrm{C}(23)$ & $109.81(10)$ \\
\hline $\mathrm{O}(1)-\mathrm{Si}(1)-\mathrm{C}(22)$ & $110.29(10)$ \\
\hline $\mathrm{C}(23)-\mathrm{Si}(1)-\mathrm{C}(24)$ & $111.72(11)$ \\
\hline C(22)-Si(1)-C(24) & $113.66(12)$ \\
\hline $\mathrm{C}(22)-\mathrm{Si}(1)-\mathrm{C}(23)$ & $108.26(13)$ \\
\hline $\mathrm{O}\left(1^{\prime}\right)-\mathrm{Si}\left(1^{\prime}\right)-\mathrm{C}\left(24^{\prime}\right)$ & $103.53(9)$ \\
\hline
\end{tabular}




\begin{tabular}{|c|c|}
\hline $\mathrm{O}\left(1^{\prime}\right)-\mathrm{Si}\left(1^{\prime}\right)-\mathrm{C}\left(23^{\prime}\right)$ & $108.93(10)$ \\
\hline $\mathrm{O}\left(1^{\prime}\right)-\mathrm{Si}\left(1^{\prime}\right)-\mathrm{C}\left(22^{\prime}\right)$ & $109.74(10)$ \\
\hline$C\left(23^{\prime}\right)-\operatorname{Si}\left(1^{\prime}\right)-C\left(24^{\prime}\right)$ & $111.25(12)$ \\
\hline$C\left(22^{\prime}\right)-\operatorname{Si}\left(1^{\prime}\right)-C\left(24^{\prime}\right)$ & $112.31(13)$ \\
\hline$C\left(22^{\prime}\right)-\operatorname{Si}\left(1^{\prime}\right)-C\left(23^{\prime}\right)$ & $110.80(14)$ \\
\hline $\mathrm{C}\left(21^{\prime}\right)-\mathrm{O}\left(2^{\prime}\right)-\mathrm{C}\left(19^{\prime}\right)$ & $114.41(14)$ \\
\hline $\mathrm{C}(21)-\mathrm{O}(2)-\mathrm{C}(19)$ & $114.56(14)$ \\
\hline $\mathrm{C}(21)-\mathrm{O}(1)-\mathrm{Si}(1)$ & $122.41(12)$ \\
\hline $\mathrm{C}(6)-\mathrm{O}(6)-\mathrm{C}(7)$ & $61.10(12)$ \\
\hline $\mathrm{C}\left(4^{\prime}\right)-\mathrm{O}\left(3^{\prime}\right)-\mathrm{C}\left(28^{\prime}\right)$ & $60.28(13)$ \\
\hline $\mathrm{C}(4)-\mathrm{O}(3)-\mathrm{C}(28)$ & $60.35(13)$ \\
\hline $\mathrm{C}(18)-\mathrm{O}(4)-\mathrm{H}(4)$ & 109.5 \\
\hline $\mathrm{C}\left(18^{\prime}\right)-\mathrm{O}\left(4^{\prime}\right)-\mathrm{H}\left(4^{\prime}\right)$ & 109.5 \\
\hline $\mathrm{C}(10)-\mathrm{O}(5)-\mathrm{H}(5)$ & 109.5 \\
\hline $\mathrm{C}\left(21^{\prime}\right)-\mathrm{O}\left(1^{\prime}\right)-\mathrm{Si}\left(1^{\prime}\right)$ & $122.87(12)$ \\
\hline $\mathrm{C}\left(10^{\prime}\right)-\mathrm{O}\left(5^{\prime}\right)-\mathrm{H}\left(5^{\prime}\right)$ & 109.5 \\
\hline $\mathrm{C}\left(6^{\prime}\right)-\mathrm{O}\left(6^{\prime}\right)-\mathrm{C}\left(7^{\prime}\right)$ & $61.66(13)$ \\
\hline $\mathrm{O}(6)-\mathrm{C}(6)-\mathrm{C}(28)$ & $117.07(17)$ \\
\hline $\mathrm{O}(6)-\mathrm{C}(6)-\mathrm{C}(7)$ & $59.80(12)$ \\
\hline $\mathrm{O}(6)-\mathrm{C}(6)-\mathrm{C}(18)$ & $115.54(16)$ \\
\hline$C(28)-C(6)-C(18)$ & $109.32(17)$ \\
\hline$C(7)-C(6)-C(28)$ & $135.53(19)$ \\
\hline$C(7)-C(6)-C(18)$ & $110.60(17)$ \\
\hline $\mathrm{H}(20 \mathrm{C})-\mathrm{C}\left(20^{\prime}\right)-\mathrm{H}(20 \mathrm{D})$ & 107.6 \\
\hline $\mathrm{C}\left(21^{\prime}\right)-\mathrm{C}\left(20^{\prime}\right)-\mathrm{H}(20 \mathrm{C})$ & 108.7 \\
\hline $\mathrm{C}\left(21^{\prime}\right)-\mathrm{C}\left(20^{\prime}\right)-\mathrm{H}(20 \mathrm{D})$ & 108.7 \\
\hline $\mathrm{C}\left(21^{\prime}\right)-\mathrm{C}\left(20^{\prime}\right)-\mathrm{C}\left(17^{\prime}\right)$ & $114.37(16)$ \\
\hline $\mathrm{C}\left(17^{\prime}\right)-\mathrm{C}\left(20^{\prime}\right)-\mathrm{H}(20 \mathrm{C})$ & 108.7 \\
\hline $\mathrm{C}\left(17^{\prime}\right)-\mathrm{C}\left(20^{\prime}\right)-\mathrm{H}(20 \mathrm{D})$ & 108.7 \\
\hline $\mathrm{O}\left(6^{\prime}\right)-\mathrm{C}\left(6^{\prime}\right)-\mathrm{C}\left(7^{\prime}\right)$ & $59.44(13)$ \\
\hline $\mathrm{O}\left(6^{\prime}\right)-\mathrm{C}\left(6^{\prime}\right)-\mathrm{C}\left(28^{\prime}\right)$ & $117.26(18)$ \\
\hline $\mathrm{O}\left(6^{\prime}\right)-\mathrm{C}\left(6^{\prime}\right)-\mathrm{C}\left(18^{\prime}\right)$ & $116.05(17)$ \\
\hline $\mathrm{C}\left(7^{\prime}\right)-\mathrm{C}\left(6^{\prime}\right)-\mathrm{C}\left(28^{\prime}\right)$ & $135.83(19)$ \\
\hline $\mathrm{C}\left(7^{\prime}\right)-\mathrm{C}\left(6^{\prime}\right)-\mathrm{C}\left(18^{\prime}\right)$ & $110.15(18)$ \\
\hline $\mathrm{C}\left(28^{\prime}\right)-\mathrm{C}\left(6^{\prime}\right)-\mathrm{C}\left(18^{\prime}\right)$ & $109.29(17)$ \\
\hline $\mathrm{O}\left(3^{\prime}\right)-\mathrm{C}\left(4^{\prime}\right)-\mathrm{C}\left(19^{\prime}\right)$ & $110.93(16)$ \\
\hline
\end{tabular}




\begin{tabular}{|c|c|}
\hline $\mathrm{O}\left(3^{\prime}\right)-\mathrm{C}\left(4^{\prime}\right)-\mathrm{C}\left(28^{\prime}\right)$ & $60.63(13)$ \\
\hline $\mathrm{O}\left(3^{\prime}\right)-\mathrm{C}\left(4^{\prime}\right)-\mathrm{C}\left(2^{\prime}\right)$ & $114.40(17)$ \\
\hline $\mathrm{C}\left(28^{\prime}\right)-\mathrm{C}\left(4^{\prime}\right)-\mathrm{C}\left(19^{\prime}\right)$ & $109.08(17)$ \\
\hline$C\left(28^{\prime}\right)-C\left(4^{\prime}\right)-C\left(2^{\prime}\right)$ & $124.23(19)$ \\
\hline$C\left(2^{\prime}\right)-C\left(4^{\prime}\right)-C\left(19^{\prime}\right)$ & $121.68(18)$ \\
\hline $\mathrm{O}(3)-\mathrm{C}(28)-\mathrm{C}(6)$ & $104.41(16)$ \\
\hline $\mathrm{O}(3)-\mathrm{C}(28)-\mathrm{C}(4)$ & $59.39(13)$ \\
\hline $\mathrm{O}(3)-\mathrm{C}(28)-\mathrm{C}(5)$ & $116.85(18)$ \\
\hline$C(6)-C(28)-C(5)$ & $123.5(2)$ \\
\hline $\mathrm{C}(4)-\mathrm{C}(28)-\mathrm{C}(6)$ & $107.34(17)$ \\
\hline$C(4)-C(28)-C(5)$ & $126.11(19)$ \\
\hline $\mathrm{O}(3)-\mathrm{C}(4)-\mathrm{C}(28)$ & $60.26(13)$ \\
\hline $\mathrm{O}(3)-\mathrm{C}(4)-\mathrm{C}(19)$ & $110.94(16)$ \\
\hline $\mathrm{O}(3)-\mathrm{C}(4)-\mathrm{C}(2)$ & $113.95(17)$ \\
\hline$C(28)-C(4)-C(19)$ & $109.09(17)$ \\
\hline $\mathrm{C}(28)-\mathrm{C}(4)-\mathrm{C}(2)$ & $124.06(19)$ \\
\hline $\mathrm{C}(2)-\mathrm{C}(4)-\mathrm{C}(19)$ & $122.13(18)$ \\
\hline $\mathrm{O}(2)-\mathrm{C}(21)-\mathrm{H}(21)$ & 108.2 \\
\hline $\mathrm{O}(2)-\mathrm{C}(21)-\mathrm{C}(20)$ & $109.15(15)$ \\
\hline $\mathrm{O}(1)-\mathrm{C}(21)-\mathrm{O}(2)$ & $111.19(16)$ \\
\hline $\mathrm{O}(1)-\mathrm{C}(21)-\mathrm{H}(21)$ & 108.2 \\
\hline $\mathrm{O}(1)-\mathrm{C}(21)-\mathrm{C}(20)$ & $111.74(16)$ \\
\hline $\mathrm{C}(20)-\mathrm{C}(21)-\mathrm{H}(21)$ & 108.2 \\
\hline $\mathrm{O}\left(2^{\prime}\right)-\mathrm{C}\left(21^{\prime}\right)-\mathrm{C}\left(20^{\prime}\right)$ & $109.18(16)$ \\
\hline $\mathrm{O}\left(2^{\prime}\right)-\mathrm{C}\left(21^{\prime}\right)-\mathrm{H}\left(21^{\prime}\right)$ & 108.4 \\
\hline $\mathrm{O}\left(1^{\prime}\right)-\mathrm{C}\left(21^{\prime}\right)-\mathrm{O}\left(2^{\prime}\right)$ & $110.82(16)$ \\
\hline $\mathrm{O}\left(1^{\prime}\right)-\mathrm{C}\left(21^{\prime}\right)-\mathrm{C}\left(20^{\prime}\right)$ & $111.48(16)$ \\
\hline $\mathrm{O}\left(1^{\prime}\right)-\mathrm{C}\left(21^{\prime}\right)-\mathrm{H}\left(21^{\prime}\right)$ & 108.4 \\
\hline $\mathrm{C}\left(20^{\prime}\right)-\mathrm{C}\left(21^{\prime}\right)-\mathrm{H}\left(21^{\prime}\right)$ & 108.4 \\
\hline$C(20)-C(17)-C(10)$ & $107.53(16)$ \\
\hline $\mathrm{C}(20)-\mathrm{C}(17)-\mathrm{C}(18)$ & $108.47(15)$ \\
\hline$C(18)-C(17)-C(10)$ & $103.56(15)$ \\
\hline$C(16)-C(17)-C(20)$ & $111.50(16)$ \\
\hline$C(16)-C(17)-C(10)$ & $112.57(16)$ \\
\hline$C(16)-C(17)-C(18)$ & $112.78(16)$ \\
\hline$C(21)-C(20)-C(17)$ & $114.40(16)$ \\
\hline
\end{tabular}




\begin{tabular}{|c|c|}
\hline $\mathrm{C}(21)-\mathrm{C}(20)-\mathrm{H}(20 \mathrm{~A})$ & 108.7 \\
\hline $\mathrm{C}(21)-\mathrm{C}(20)-\mathrm{H}(20 \mathrm{~B})$ & 108.7 \\
\hline $\mathrm{C}(17)-\mathrm{C}(20)-\mathrm{H}(20 \mathrm{~A})$ & 108.7 \\
\hline $\mathrm{C}(17)-\mathrm{C}(20)-\mathrm{H}(20 \mathrm{~B})$ & 108.7 \\
\hline $\mathrm{H}(20 \mathrm{~A})-\mathrm{C}(20)-\mathrm{H}(20 \mathrm{~B})$ & 107.6 \\
\hline $\mathrm{C}(7)-\mathrm{C}(8)-\mathrm{H}(8)$ & 117.6 \\
\hline $\mathrm{C}(9)-\mathrm{C}(8)-\mathrm{H}(8)$ & 117.6 \\
\hline$C(9)-C(8)-C(7)$ & $124.9(2)$ \\
\hline $\mathrm{O}(2)-\mathrm{C}(19)-\mathrm{C}(4)$ & $103.08(15)$ \\
\hline $\mathrm{O}(2)-\mathrm{C}(19)-\mathrm{H}(19)$ & 111.1 \\
\hline $\mathrm{O}(2)-\mathrm{C}(19)-\mathrm{C}(18)$ & $115.63(16)$ \\
\hline $\mathrm{C}(4)-\mathrm{C}(19)-\mathrm{H}(19)$ & 111.1 \\
\hline$C(4)-C(19)-C(18)$ & $104.26(16)$ \\
\hline $\mathrm{C}(18)-\mathrm{C}(19)-\mathrm{H}(19)$ & 111.1 \\
\hline $\mathrm{O}(5)-\mathrm{C}(10)-\mathrm{C}(17)$ & $111.19(16)$ \\
\hline $\mathrm{O}(5)-\mathrm{C}(10)-\mathrm{C}(7)$ & $108.12(16)$ \\
\hline $\mathrm{O}(5)-\mathrm{C}(10)-\mathrm{C}(11)$ & $104.75(16)$ \\
\hline$C(7)-C(10)-C(17)$ & $103.82(16)$ \\
\hline$C(11)-C(10)-C(17)$ & $117.29(17)$ \\
\hline$C(11)-C(10)-C(7)$ & $111.50(17)$ \\
\hline $\mathrm{O}(6)-\mathrm{C}(7)-\mathrm{C}(6)$ & $59.11(12)$ \\
\hline $\mathrm{O}(6)-\mathrm{C}(7)-\mathrm{C}(8)$ & $115.69(17)$ \\
\hline $\mathrm{O}(6)-\mathrm{C}(7)-\mathrm{C}(10)$ & $108.16(16)$ \\
\hline $\mathrm{C}(6)-\mathrm{C}(7)-\mathrm{C}(8)$ & $126.47(19)$ \\
\hline$C(6)-C(7)-C(10)$ & $107.01(17)$ \\
\hline $\mathrm{C}(8)-\mathrm{C}(7)-\mathrm{C}(10)$ & $122.60(18)$ \\
\hline $\mathrm{O}\left(2^{\prime}\right)-\mathrm{C}\left(19^{\prime}\right)-\mathrm{C}\left(4^{\prime}\right)$ & $103.07(15)$ \\
\hline $\mathrm{O}\left(2^{\prime}\right)-\mathrm{C}\left(19^{\prime}\right)-\mathrm{H}\left(19^{\prime}\right)$ & 111.1 \\
\hline $\mathrm{O}\left(2^{\prime}\right)-\mathrm{C}\left(19^{\prime}\right)-\mathrm{C}\left(18^{\prime}\right)$ & $115.53(16)$ \\
\hline $\mathrm{C}\left(4^{\prime}\right)-\mathrm{C}\left(19^{\prime}\right)-\mathrm{H}\left(19^{\prime}\right)$ & 111.1 \\
\hline $\mathrm{C}\left(4^{\prime}\right)-\mathrm{C}\left(19^{\prime}\right)-\mathrm{C}\left(18^{\prime}\right)$ & $104.43(16)$ \\
\hline $\mathrm{C}\left(18^{\prime}\right)-\mathrm{C}\left(19^{\prime}\right)-\mathrm{H}\left(19^{\prime}\right)$ & 111.1 \\
\hline $\mathrm{O}\left(6^{\prime}\right)-\mathrm{C}\left(7^{\prime}\right)-\mathrm{C}\left(6^{\prime}\right)$ & $58.90(13)$ \\
\hline $\mathrm{O}\left(6^{\prime}\right)-\mathrm{C}\left(7^{\prime}\right)-\mathrm{C}\left(8^{\prime}\right)$ & $116.05(19)$ \\
\hline $\mathrm{O}\left(6^{\prime}\right)-\mathrm{C}\left(7^{\prime}\right)-\mathrm{C}\left(10^{\prime}\right)$ & $108.29(17)$ \\
\hline$C\left(6^{\prime}\right)-C\left(7^{\prime}\right)-C\left(10^{\prime}\right)$ & $106.80(18)$ \\
\hline
\end{tabular}




\begin{tabular}{|c|c|}
\hline$C\left(8^{\prime}\right)-C\left(7^{\prime}\right)-C\left(6^{\prime}\right)$ & $124.4(2)$ \\
\hline$C\left(8^{\prime}\right)-C\left(7^{\prime}\right)-C\left(10^{\prime}\right)$ & $124.1(2)$ \\
\hline $\mathrm{O}(4)-\mathrm{C}(18)-\mathrm{C}(6)$ & $112.15(15)$ \\
\hline $\mathrm{O}(4)-\mathrm{C}(18)-\mathrm{C}(17)$ & $108.51(15)$ \\
\hline $\mathrm{O}(4)-\mathrm{C}(18)-\mathrm{C}(19)$ & $109.15(16)$ \\
\hline$C(6)-C(18)-C(17)$ & $105.12(16)$ \\
\hline$C(6)-C(18)-C(19)$ & $103.54(16)$ \\
\hline$C(19)-C(18)-C(17)$ & $118.28(16)$ \\
\hline $\mathrm{O}\left(3^{\prime}\right)-\mathrm{C}\left(28^{\prime}\right)-\mathrm{C}\left(6^{\prime}\right)$ & $104.43(16)$ \\
\hline $\mathrm{O}\left(3^{\prime}\right)-\mathrm{C}\left(28^{\prime}\right)-\mathrm{C}\left(5^{\prime}\right)$ & $116.04(18)$ \\
\hline $\mathrm{C}\left(6^{\prime}\right)-\mathrm{C}\left(28^{\prime}\right)-\mathrm{C}\left(5^{\prime}\right)$ & $123.8(2)$ \\
\hline $\mathrm{C}\left(4^{\prime}\right)-\mathrm{C}\left(28^{\prime}\right)-\mathrm{O}\left(3^{\prime}\right)$ & $59.09(13)$ \\
\hline $\mathrm{C}\left(4^{\prime}\right)-\mathrm{C}\left(28^{\prime}\right)-\mathrm{C}\left(6^{\prime}\right)$ & $107.15(17)$ \\
\hline $\mathrm{C}\left(4^{\prime}\right)-\mathrm{C}\left(28^{\prime}\right)-\mathrm{C}\left(5^{\prime}\right)$ & $126.3(2)$ \\
\hline $\mathrm{H}(16 \mathrm{D})-\mathrm{C}\left(16^{\prime}\right)-\mathrm{H}(16 \mathrm{E})$ & 109.5 \\
\hline $\mathrm{H}(16 \mathrm{D})-\mathrm{C}\left(16^{\prime}\right)-\mathrm{H}(16 \mathrm{~F})$ & 109.5 \\
\hline $\mathrm{H}(16 \mathrm{E})-\mathrm{C}\left(16^{\prime}\right)-\mathrm{H}(16 \mathrm{~F})$ & 109.5 \\
\hline $\mathrm{C}\left(17^{\prime}\right)-\mathrm{C}\left(16^{\prime}\right)-\mathrm{H}(16 \mathrm{D})$ & 109.5 \\
\hline$C\left(17^{\prime}\right)-C\left(16^{\prime}\right)-H(16 E)$ & 109.5 \\
\hline $\mathrm{C}\left(17^{\prime}\right)-\mathrm{C}\left(16^{\prime}\right)-\mathrm{H}(16 \mathrm{~F})$ & 109.5 \\
\hline $\mathrm{C}\left(7^{\prime}\right)-\mathrm{C}\left(8^{\prime}\right)-\mathrm{H}\left(8^{\prime}\right)$ & 117.7 \\
\hline $\mathrm{C}\left(9^{\prime}\right)-\mathrm{C}\left(8^{\prime}\right)-\mathrm{C}\left(7^{\prime}\right)$ & $124.6(2)$ \\
\hline $\mathrm{C}\left(9^{\prime}\right)-\mathrm{C}\left(8^{\prime}\right)-\mathrm{H}\left(8^{\prime}\right)$ & 117.7 \\
\hline $\mathrm{O}\left(5^{\prime}\right)-\mathrm{C}\left(10^{\prime}\right)-\mathrm{C}\left(7^{\prime}\right)$ & $108.69(17)$ \\
\hline $\mathrm{O}\left(5^{\prime}\right)-\mathrm{C}\left(10^{\prime}\right)-\mathrm{C}\left(17^{\prime}\right)$ & $110.50(17)$ \\
\hline $\mathrm{O}\left(5^{\prime}\right)-\mathrm{C}\left(10^{\prime}\right)-\mathrm{C}\left(11^{\prime}\right)$ & $105.11(17)$ \\
\hline $\mathrm{C}\left(7^{\prime}\right)-\mathrm{C}\left(10^{\prime}\right)-\mathrm{C}\left(17^{\prime}\right)$ & $103.69(16)$ \\
\hline $\mathrm{C}\left(11^{\prime}\right)-\mathrm{C}\left(10^{\prime}\right)-\mathrm{C}\left(7^{\prime}\right)$ & $115.60(19)$ \\
\hline $\mathrm{C}\left(11^{\prime}\right)-\mathrm{C}\left(10^{\prime}\right)-\mathrm{C}\left(17^{\prime}\right)$ & $113.27(17)$ \\
\hline $\mathrm{C}\left(20^{\prime}\right)-\mathrm{C}\left(17^{\prime}\right)-\mathrm{C}\left(10^{\prime}\right)$ & $108.19(16)$ \\
\hline $\mathrm{C}\left(20^{\prime}\right)-\mathrm{C}\left(17^{\prime}\right)-\mathrm{C}\left(18^{\prime}\right)$ & $109.40(16)$ \\
\hline $\mathrm{C}\left(16^{\prime}\right)-\mathrm{C}\left(17^{\prime}\right)-\mathrm{C}\left(20^{\prime}\right)$ & $111.07(17)$ \\
\hline $\mathrm{C}\left(16^{\prime}\right)-\mathrm{C}\left(17^{\prime}\right)-\mathrm{C}\left(10^{\prime}\right)$ & $111.80(17)$ \\
\hline $\mathrm{C}\left(16^{\prime}\right)-\mathrm{C}\left(17^{\prime}\right)-\mathrm{C}\left(18^{\prime}\right)$ & $112.38(17)$ \\
\hline $\mathrm{C}\left(18^{\prime}\right)-\mathrm{C}\left(17^{\prime}\right)-\mathrm{C}\left(10^{\prime}\right)$ & $103.68(16)$ \\
\hline $\mathrm{C}(17)-\mathrm{C}(16)-\mathrm{H}(16 \mathrm{~A})$ & 109.5 \\
\hline
\end{tabular}




\begin{tabular}{|c|c|}
\hline $\mathrm{C}(17)-\mathrm{C}(16)-\mathrm{H}(16 \mathrm{~B})$ & 109.5 \\
\hline $\mathrm{C}(17)-\mathrm{C}(16)-\mathrm{H}(16 \mathrm{C})$ & 109.5 \\
\hline $\mathrm{H}(16 \mathrm{~A})-\mathrm{C}(16)-\mathrm{H}(16 \mathrm{~B})$ & 109.5 \\
\hline $\mathrm{H}(16 \mathrm{~A})-\mathrm{C}(16)-\mathrm{H}(16 \mathrm{C})$ & 109.5 \\
\hline $\mathrm{H}(16 \mathrm{~B})-\mathrm{C}(16)-\mathrm{H}(16 \mathrm{C})$ & 109.5 \\
\hline $\mathrm{C}(10)-\mathrm{C}(11)-\mathrm{H}(11 \mathrm{~A})$ & 108.1 \\
\hline $\mathrm{C}(10)-\mathrm{C}(11)-\mathrm{H}(11 \mathrm{~B})$ & 108.1 \\
\hline$C(10)-C(11)-C(12)$ & $116.66(19)$ \\
\hline $\mathrm{H}(11 \mathrm{~A})-\mathrm{C}(11)-\mathrm{H}(11 \mathrm{~B})$ & 107.3 \\
\hline $\mathrm{C}(12)-\mathrm{C}(11)-\mathrm{H}(11 \mathrm{~A})$ & 108.1 \\
\hline $\mathrm{C}(12)-\mathrm{C}(11)-\mathrm{H}(11 \mathrm{~B})$ & 108.1 \\
\hline $\mathrm{O}\left(4^{\prime}\right)-\mathrm{C}\left(18^{\prime}\right)-\mathrm{C}\left(6^{\prime}\right)$ & $112.62(16)$ \\
\hline $\mathrm{O}\left(4^{\prime}\right)-\mathrm{C}\left(18^{\prime}\right)-\mathrm{C}\left(19^{\prime}\right)$ & $109.00(16)$ \\
\hline $\mathrm{O}\left(4^{\prime}\right)-\mathrm{C}\left(18^{\prime}\right)-\mathrm{C}\left(17^{\prime}\right)$ & $108.55(15)$ \\
\hline $\mathrm{C}\left(6^{\prime}\right)-\mathrm{C}\left(18^{\prime}\right)-\mathrm{C}\left(19^{\prime}\right)$ & $103.53(16)$ \\
\hline $\mathrm{C}\left(6^{\prime}\right)-\mathrm{C}\left(18^{\prime}\right)-\mathrm{C}\left(17^{\prime}\right)$ & $105.22(16)$ \\
\hline $\mathrm{C}\left(19^{\prime}\right)-\mathrm{C}\left(18^{\prime}\right)-\mathrm{C}\left(17^{\prime}\right)$ & $117.90(16)$ \\
\hline $\mathrm{C}\left(10^{\prime}\right)-\mathrm{C}\left(11^{\prime}\right)-\mathrm{H}(11 \mathrm{C})$ & 108.7 \\
\hline $\mathrm{C}\left(10^{\prime}\right)-\mathrm{C}\left(11^{\prime}\right)-\mathrm{H}(11 \mathrm{D})$ & 108.7 \\
\hline $\mathrm{H}(11 \mathrm{C})-\mathrm{C}\left(11^{\prime}\right)-\mathrm{H}(11 \mathrm{D})$ & 107.6 \\
\hline $\mathrm{C}\left(12^{\prime}\right)-\mathrm{C}\left(11^{\prime}\right)-\mathrm{C}\left(10^{\prime}\right)$ & $114.41(19)$ \\
\hline $\mathrm{C}\left(12^{\prime}\right)-\mathrm{C}\left(11^{\prime}\right)-\mathrm{H}(11 \mathrm{C})$ & 108.7 \\
\hline $\mathrm{C}\left(12^{\prime}\right)-\mathrm{C}\left(11^{\prime}\right)-\mathrm{H}(11 \mathrm{D})$ & 108.7 \\
\hline$C(27)-C(24)-S i(1)$ & $109.35(17)$ \\
\hline$C(27)-C(24)-C(25)$ & $109.4(2)$ \\
\hline$C(27)-C(24)-C(26)$ & $109.7(2)$ \\
\hline$C(25)-C(24)-S i(1)$ & $109.00(16)$ \\
\hline$C(26)-C(24)-\operatorname{Si}(1)$ & $110.05(17)$ \\
\hline$C(26)-C(24)-C(25)$ & $109.3(2)$ \\
\hline $\mathrm{C}\left(4^{\prime}\right)-\mathrm{C}\left(2^{\prime}\right)-\mathrm{H}\left(2^{\prime}\right)$ & 107.2 \\
\hline$C\left(4^{\prime}\right)-C\left(2^{\prime}\right)-C\left(1^{\prime}\right)$ & $110.67(17)$ \\
\hline $\mathrm{C}\left(4^{\prime}\right)-\mathrm{C}\left(2^{\prime}\right)-\mathrm{C}\left(3^{\prime}\right)$ & $112.59(18)$ \\
\hline $\mathrm{C}\left(1^{\prime}\right)-\mathrm{C}\left(2^{\prime}\right)-\mathrm{H}\left(2^{\prime}\right)$ & 107.2 \\
\hline $\mathrm{C}\left(1^{\prime}\right)-\mathrm{C}\left(2^{\prime}\right)-\mathrm{C}\left(3^{\prime}\right)$ & $111.6(2)$ \\
\hline $\mathrm{C}\left(3^{\prime}\right)-\mathrm{C}\left(2^{\prime}\right)-\mathrm{H}\left(2^{\prime}\right)$ & 107.2 \\
\hline$C\left(27^{\prime}\right)-C\left(24^{\prime}\right)-\operatorname{Si}\left(1^{\prime}\right)$ & $110.61(17)$ \\
\hline
\end{tabular}




\begin{tabular}{|c|c|}
\hline$C\left(27^{\prime}\right)-C\left(24^{\prime}\right)-C\left(26^{\prime}\right)$ & $108.8(2)$ \\
\hline $\mathrm{C}\left(27^{\prime}\right)-\mathrm{C}\left(24^{\prime}\right)-\mathrm{C}\left(25^{\prime}\right)$ & $108.2(2)$ \\
\hline $\mathrm{C}\left(26^{\prime}\right)-\mathrm{C}\left(24^{\prime}\right)-\mathrm{Si}\left(1^{\prime}\right)$ & $110.12(18)$ \\
\hline $\mathrm{C}\left(25^{\prime}\right)-\mathrm{C}\left(24^{\prime}\right)-\mathrm{Si}\left(1^{\prime}\right)$ & $109.10(19)$ \\
\hline $\mathrm{C}\left(25^{\prime}\right)-\mathrm{C}\left(24^{\prime}\right)-\mathrm{C}\left(26^{\prime}\right)$ & $110.0(2)$ \\
\hline $\mathrm{C}\left(2^{\prime}\right)-\mathrm{C}\left(1^{\prime}\right)-\mathrm{H}\left(1^{\prime} \mathrm{A}\right)$ & 109.5 \\
\hline $\mathrm{C}\left(2^{\prime}\right)-\mathrm{C}\left(1^{\prime}\right)-\mathrm{H}\left(1^{\prime} \mathrm{B}\right)$ & 109.5 \\
\hline $\mathrm{C}\left(2^{\prime}\right)-\mathrm{C}\left(1^{\prime}\right)-\mathrm{H}\left(1^{\prime} \mathrm{C}\right)$ & 109.5 \\
\hline H(1'A)-C(1')-H(1'B) & 109.5 \\
\hline $\mathrm{H}\left(1^{\prime} \mathrm{A}\right)-\mathrm{C}\left(1^{\prime}\right)-\mathrm{H}\left(1^{\prime} \mathrm{C}\right)$ & 109.5 \\
\hline $\mathrm{H}\left(1^{\prime} \mathrm{B}\right)-\mathrm{C}\left(1^{\prime}\right)-\mathrm{H}\left(1^{\prime} \mathrm{C}\right)$ & 109.5 \\
\hline $\mathrm{H}(1 \mathrm{~A})-\mathrm{C}(1)-\mathrm{H}(1 \mathrm{~B})$ & 109.5 \\
\hline $\mathrm{H}(1 \mathrm{~A})-\mathrm{C}(1)-\mathrm{H}(1 \mathrm{C})$ & 109.5 \\
\hline $\mathrm{H}(1 \mathrm{~B})-\mathrm{C}(1)-\mathrm{H}(1 \mathrm{C})$ & 109.5 \\
\hline $\mathrm{C}(2)-\mathrm{C}(1)-\mathrm{H}(1 \mathrm{~A})$ & 109.5 \\
\hline $\mathrm{C}(2)-\mathrm{C}(1)-\mathrm{H}(1 \mathrm{~B})$ & 109.5 \\
\hline $\mathrm{C}(2)-\mathrm{C}(1)-\mathrm{H}(1 \mathrm{C})$ & 109.5 \\
\hline$C(4)-C(2)-C(1)$ & $113.05(19)$ \\
\hline $\mathrm{C}(4)-\mathrm{C}(2)-\mathrm{H}(2)$ & 106.9 \\
\hline $\mathrm{C}(4)-\mathrm{C}(2)-\mathrm{C}(3)$ & $111.43(19)$ \\
\hline $\mathrm{C}(1)-\mathrm{C}(2)-\mathrm{H}(2)$ & 106.9 \\
\hline $\mathrm{C}(3)-\mathrm{C}(2)-\mathrm{C}(1)$ & $111.4(2)$ \\
\hline $\mathrm{C}(3)-\mathrm{C}(2)-\mathrm{H}(2)$ & 106.9 \\
\hline $\mathrm{C}(8)-\mathrm{C}(9)-\mathrm{H}(9 \mathrm{~A})$ & 120.0 \\
\hline $\mathrm{C}(8)-\mathrm{C}(9)-\mathrm{H}(9 \mathrm{~B})$ & 120.0 \\
\hline $\mathrm{H}(9 \mathrm{~A})-\mathrm{C}(9)-\mathrm{H}(9 \mathrm{~B})$ & 120.0 \\
\hline$C(15)-C(13)-C(12)$ & $116.1(2)$ \\
\hline $\mathrm{C}(14)-\mathrm{C}(13)-\mathrm{C}(12)$ & $121.6(2)$ \\
\hline$C(14)-C(13)-C(15)$ & $122.2(3)$ \\
\hline $\mathrm{C}\left(11^{\prime}\right)-\mathrm{C}\left(12^{\prime}\right)-\mathrm{H}(12 \mathrm{C})$ & 108.3 \\
\hline $\mathrm{C}\left(11^{\prime}\right)-\mathrm{C}\left(12^{\prime}\right)-\mathrm{H}(12 \mathrm{D})$ & 108.3 \\
\hline $\mathrm{H}(12 \mathrm{C})-\mathrm{C}\left(12^{\prime}\right)-\mathrm{H}(12 \mathrm{D})$ & 107.4 \\
\hline $\mathrm{C}\left(13^{\prime}\right)-\mathrm{C}\left(12^{\prime}\right)-\mathrm{C}\left(11^{\prime}\right)$ & $116.0(2)$ \\
\hline $\mathrm{C}\left(13^{\prime}\right)-\mathrm{C}\left(12^{\prime}\right)-\mathrm{H}(12 \mathrm{C})$ & 108.3 \\
\hline $\mathrm{C}\left(13^{\prime}\right)-\mathrm{C}\left(12^{\prime}\right)-\mathrm{H}(12 \mathrm{D})$ & 108.3 \\
\hline $\mathrm{C}\left(28^{\prime}\right)-\mathrm{C}\left(5^{\prime}\right)-\mathrm{H}\left(5^{\prime} \mathrm{A}\right)$ & 109.5 \\
\hline
\end{tabular}




\begin{tabular}{|c|c|}
\hline $\mathrm{C}\left(28^{\prime}\right)-\mathrm{C}\left(5^{\prime}\right)-\mathrm{H}\left(5^{\prime} \mathrm{B}\right)$ & 109.5 \\
\hline $\mathrm{C}\left(28^{\prime}\right)-\mathrm{C}\left(5^{\prime}\right)-\mathrm{H}\left(5^{\prime} \mathrm{C}\right)$ & 109.5 \\
\hline $\mathrm{H}\left(5^{\prime} \mathrm{A}\right)-\mathrm{C}\left(5^{\prime}\right)-\mathrm{H}\left(5^{\prime} \mathrm{B}\right)$ & 109.5 \\
\hline $\mathrm{H}\left(5^{\prime} \mathrm{A}\right)-\mathrm{C}\left(5^{\prime}\right)-\mathrm{H}\left(5^{\prime} \mathrm{C}\right)$ & 109.5 \\
\hline $\mathrm{H}\left(5^{\prime} \mathrm{B}\right)-\mathrm{C}\left(5^{\prime}\right)-\mathrm{H}\left(5^{\prime} \mathrm{C}\right)$ & 109.5 \\
\hline $\operatorname{Si}\left(1^{\prime}\right)-C\left(23^{\prime}\right)-H(23 D)$ & 109.5 \\
\hline $\mathrm{Si}\left(1^{\prime}\right)-\mathrm{C}\left(23^{\prime}\right)-\mathrm{H}(23 \mathrm{E})$ & 109.5 \\
\hline $\mathrm{Si}\left(1^{\prime}\right)-\mathrm{C}\left(23^{\prime}\right)-\mathrm{H}(23 \mathrm{~F})$ & 109.5 \\
\hline $\mathrm{H}(23 \mathrm{D})-\mathrm{C}\left(23^{\prime}\right)-\mathrm{H}(23 \mathrm{E})$ & 109.5 \\
\hline $\mathrm{H}(23 \mathrm{D})-\mathrm{C}\left(23^{\prime}\right)-\mathrm{H}(23 \mathrm{~F})$ & 109.5 \\
\hline $\mathrm{H}(23 \mathrm{E})-\mathrm{C}\left(23^{\prime}\right)-\mathrm{H}(23 \mathrm{~F})$ & 109.5 \\
\hline $\mathrm{C}(11)-\mathrm{C}(12)-\mathrm{H}(12 \mathrm{~A})$ & 109.6 \\
\hline $\mathrm{C}(11)-\mathrm{C}(12)-\mathrm{H}(12 \mathrm{~B})$ & 109.6 \\
\hline$C(13)-C(12)-C(11)$ & $110.2(2)$ \\
\hline $\mathrm{C}(13)-\mathrm{C}(12)-\mathrm{H}(12 \mathrm{~A})$ & 109.6 \\
\hline $\mathrm{C}(13)-\mathrm{C}(12)-\mathrm{H}(12 \mathrm{~B})$ & 109.6 \\
\hline $\mathrm{H}(12 \mathrm{~A})-\mathrm{C}(12)-\mathrm{H}(12 \mathrm{~B})$ & 108.1 \\
\hline $\mathrm{Si}(1)-\mathrm{C}(23)-\mathrm{H}(23 \mathrm{~A})$ & 109.5 \\
\hline $\mathrm{Si}(1)-\mathrm{C}(23)-\mathrm{H}(23 \mathrm{~B})$ & 109.5 \\
\hline $\mathrm{Si}(1)-\mathrm{C}(23)-\mathrm{H}(23 \mathrm{C})$ & 109.5 \\
\hline $\mathrm{H}(23 \mathrm{~A})-\mathrm{C}(23)-\mathrm{H}(23 \mathrm{~B})$ & 109.5 \\
\hline $\mathrm{H}(23 \mathrm{~A})-\mathrm{C}(23)-\mathrm{H}(23 \mathrm{C})$ & 109.5 \\
\hline $\mathrm{H}(23 \mathrm{~B})-\mathrm{C}(23)-\mathrm{H}(23 \mathrm{C})$ & 109.5 \\
\hline $\mathrm{C}(28)-\mathrm{C}(5)-\mathrm{H}(5 \mathrm{~A})$ & 109.5 \\
\hline $\mathrm{C}(28)-\mathrm{C}(5)-\mathrm{H}(5 \mathrm{~B})$ & 109.5 \\
\hline $\mathrm{C}(28)-\mathrm{C}(5)-\mathrm{H}(5 \mathrm{C})$ & 109.5 \\
\hline $\mathrm{H}(5 \mathrm{~A})-\mathrm{C}(5)-\mathrm{H}(5 \mathrm{~B})$ & 109.5 \\
\hline $\mathrm{H}(5 \mathrm{~A})-\mathrm{C}(5)-\mathrm{H}(5 \mathrm{C})$ & 109.5 \\
\hline $\mathrm{H}(5 \mathrm{~B})-\mathrm{C}(5)-\mathrm{H}(5 \mathrm{C})$ & 109.5 \\
\hline $\mathrm{C}(2)-\mathrm{C}(3)-\mathrm{H}(3 \mathrm{~A})$ & 109.5 \\
\hline $\mathrm{C}(2)-\mathrm{C}(3)-\mathrm{H}(3 \mathrm{~B})$ & 109.5 \\
\hline $\mathrm{C}(2)-\mathrm{C}(3)-\mathrm{H}(3 \mathrm{C})$ & 109.5 \\
\hline $\mathrm{H}(3 \mathrm{~A})-\mathrm{C}(3)-\mathrm{H}(3 \mathrm{~B})$ & 109.5 \\
\hline $\mathrm{H}(3 \mathrm{~A})-\mathrm{C}(3)-\mathrm{H}(3 \mathrm{C})$ & 109.5 \\
\hline $\mathrm{H}(3 \mathrm{~B})-\mathrm{C}(3)-\mathrm{H}(3 \mathrm{C})$ & 109.5 \\
\hline $\mathrm{C}\left(15^{\prime}\right)-\mathrm{C}\left(13^{\prime}\right)-\mathrm{C}\left(12^{\prime}\right)$ & $114.1(2)$ \\
\hline
\end{tabular}




\begin{tabular}{|c|c|}
\hline $\mathrm{C}\left(14^{\prime}\right)-\mathrm{C}\left(13^{\prime}\right)-\mathrm{C}\left(12^{\prime}\right)$ & $124.7(2)$ \\
\hline$C\left(14^{\prime}\right)-C\left(13^{\prime}\right)-C\left(15^{\prime}\right)$ & $121.2(3)$ \\
\hline $\mathrm{C}\left(2^{\prime}\right)-\mathrm{C}\left(3^{\prime}\right)-\mathrm{H}\left(3^{\prime} \mathrm{A}\right)$ & 109.5 \\
\hline $\mathrm{C}\left(2^{\prime}\right)-\mathrm{C}\left(3^{\prime}\right)-\mathrm{H}\left(3^{\prime} \mathrm{B}\right)$ & 109.5 \\
\hline $\mathrm{C}\left(2^{\prime}\right)-\mathrm{C}\left(3^{\prime}\right)-\mathrm{H}\left(3^{\prime} \mathrm{C}\right)$ & 109.5 \\
\hline $\mathrm{H}\left(3^{\prime} \mathrm{A}\right)-\mathrm{C}\left(3^{\prime}\right)-\mathrm{H}\left(3^{\prime} \mathrm{B}\right)$ & 109.5 \\
\hline $\mathrm{H}\left(3^{\prime} \mathrm{A}\right)-\mathrm{C}\left(3^{\prime}\right)-\mathrm{H}\left(3^{\prime} \mathrm{C}\right)$ & 109.5 \\
\hline $\mathrm{H}\left(3^{\prime} \mathrm{B}\right)-\mathrm{C}\left(3^{\prime}\right)-\mathrm{H}\left(3^{\prime} \mathrm{C}\right)$ & 109.5 \\
\hline $\mathrm{C}(13)-\mathrm{C}(15)-\mathrm{H}(15 \mathrm{~A})$ & 109.5 \\
\hline $\mathrm{C}(13)-\mathrm{C}(15)-\mathrm{H}(15 \mathrm{~B})$ & 109.5 \\
\hline $\mathrm{C}(13)-\mathrm{C}(15)-\mathrm{H}(15 \mathrm{C})$ & 109.5 \\
\hline $\mathrm{H}(15 \mathrm{~A})-\mathrm{C}(15)-\mathrm{H}(15 \mathrm{~B})$ & 109.5 \\
\hline $\mathrm{H}(15 \mathrm{~A})-\mathrm{C}(15)-\mathrm{H}(15 \mathrm{C})$ & 109.5 \\
\hline $\mathrm{H}(15 \mathrm{~B})-\mathrm{C}(15)-\mathrm{H}(15 \mathrm{C})$ & 109.5 \\
\hline $\mathrm{Si}(1)-\mathrm{C}(22)-\mathrm{H}(22 \mathrm{~A})$ & 109.5 \\
\hline $\mathrm{Si}(1)-\mathrm{C}(22)-\mathrm{H}(22 \mathrm{~B})$ & 109.5 \\
\hline $\mathrm{Si}(1)-\mathrm{C}(22)-\mathrm{H}(22 \mathrm{C})$ & 109.5 \\
\hline $\mathrm{H}(22 \mathrm{~A})-\mathrm{C}(22)-\mathrm{H}(22 \mathrm{~B})$ & 109.5 \\
\hline $\mathrm{H}(22 \mathrm{~A})-\mathrm{C}(22)-\mathrm{H}(22 \mathrm{C})$ & 109.5 \\
\hline $\mathrm{H}(22 \mathrm{~B})-\mathrm{C}(22)-\mathrm{H}(22 \mathrm{C})$ & 109.5 \\
\hline $\mathrm{C}\left(24^{\prime}\right)-\mathrm{C}\left(27^{\prime}\right)-\mathrm{H}(27 \mathrm{D})$ & 109.5 \\
\hline $\mathrm{C}\left(24^{\prime}\right)-\mathrm{C}\left(27^{\prime}\right)-\mathrm{H}(27 \mathrm{E})$ & 109.5 \\
\hline $\mathrm{C}\left(24^{\prime}\right)-\mathrm{C}\left(27^{\prime}\right)-\mathrm{H}(27 \mathrm{~F})$ & 109.5 \\
\hline $\mathrm{H}(27 \mathrm{D})-\mathrm{C}\left(27^{\prime}\right)-\mathrm{H}(27 \mathrm{E})$ & 109.5 \\
\hline $\mathrm{H}(27 \mathrm{D})-\mathrm{C}\left(27^{\prime}\right)-\mathrm{H}(27 \mathrm{~F})$ & 109.5 \\
\hline $\mathrm{H}(27 \mathrm{E})-\mathrm{C}\left(27^{\prime}\right)-\mathrm{H}(27 \mathrm{~F})$ & 109.5 \\
\hline $\mathrm{C}\left(8^{\prime}\right)-\mathrm{C}\left(9^{\prime}\right)-\mathrm{H}\left(9^{\prime} \mathrm{A}\right)$ & 120.0 \\
\hline $\mathrm{C}\left(8^{\prime}\right)-\mathrm{C}\left(9^{\prime}\right)-\mathrm{H}\left(9^{\prime} \mathrm{B}\right)$ & 120.0 \\
\hline $\mathrm{H}\left(9^{\prime} \mathrm{A}\right)-\mathrm{C}\left(9^{\prime}\right)-\mathrm{H}\left(9^{\prime} \mathrm{B}\right)$ & 120.0 \\
\hline $\mathrm{C}(24)-\mathrm{C}(27)-\mathrm{H}(27 \mathrm{~A})$ & 109.5 \\
\hline $\mathrm{C}(24)-\mathrm{C}(27)-\mathrm{H}(27 \mathrm{~B})$ & 109.5 \\
\hline $\mathrm{C}(24)-\mathrm{C}(27)-\mathrm{H}(27 \mathrm{C})$ & 109.5 \\
\hline $\mathrm{H}(27 \mathrm{~A})-\mathrm{C}(27)-\mathrm{H}(27 \mathrm{~B})$ & 109.5 \\
\hline $\mathrm{H}(27 \mathrm{~A})-\mathrm{C}(27)-\mathrm{H}(27 \mathrm{C})$ & 109.5 \\
\hline $\mathrm{H}(27 \mathrm{~B})-\mathrm{C}(27)-\mathrm{H}(27 \mathrm{C})$ & 109.5 \\
\hline $\mathrm{C}\left(13^{\prime}\right)-\mathrm{C}\left(15^{\prime}\right)-\mathrm{H}(15 \mathrm{D})$ & 109.5 \\
\hline
\end{tabular}




\begin{tabular}{|c|c|}
\hline $\mathrm{C}\left(13^{\prime}\right)-\mathrm{C}\left(15^{\prime}\right)-\mathrm{H}(15 \mathrm{E})$ & $10 s$ \\
\hline $\mathrm{C}\left(13^{\prime}\right)-\mathrm{C}\left(15^{\prime}\right)-\mathrm{H}(15 \mathrm{~F})$ & 109. \\
\hline $\mathrm{H}(15 \mathrm{D})-\mathrm{C}\left(15^{\prime}\right)-\mathrm{H}(15 \mathrm{E})$ & 109. \\
\hline $\mathrm{H}(15 \mathrm{D})-\mathrm{C}\left(15^{\prime}\right)-\mathrm{H}(15 \mathrm{~F})$ & 109 \\
\hline $\mathrm{H}(15 \mathrm{E})-\mathrm{C}\left(15^{\prime}\right)-\mathrm{H}(15 \mathrm{~F})$ & 10 \\
\hline $\mathrm{Si}\left(1^{\prime}\right)-\mathrm{C}\left(22^{\prime}\right)-\mathrm{H}(22 \mathrm{D})$ & 100 \\
\hline $\mathrm{Si}\left(1^{\prime}\right)-\mathrm{C}\left(22^{\prime}\right)-\mathrm{H}(22 \mathrm{E})$ & 109 \\
\hline $\mathrm{Si}\left(1^{\prime}\right)-\mathrm{C}\left(22^{\prime}\right)-\mathrm{H}(22 \mathrm{~F})$ & 100 \\
\hline $\mathrm{H}(22 \mathrm{D})-\mathrm{C}\left(22^{\prime}\right)-\mathrm{H}(22 \mathrm{E})$ & 109.5 \\
\hline $\mathrm{H}(22 \mathrm{D})-\mathrm{C}\left(22^{\prime}\right)-\mathrm{H}(22 \mathrm{~F})$ & 109. \\
\hline $\mathrm{H}(22 \mathrm{E})-\mathrm{C}\left(22^{\prime}\right)-\mathrm{H}(22 \mathrm{~F})$ & 109.5 \\
\hline $\mathrm{C}(13)-\mathrm{C}(14)-\mathrm{H}(14 \mathrm{~A})$ & 12 \\
\hline $\mathrm{C}(13)-\mathrm{C}(14)-\mathrm{H}(14 \mathrm{~B})$ & 120 \\
\hline H(14A)-C(14)-H(14B) & 120. \\
\hline $\mathrm{C}\left(24^{\prime}\right)-\mathrm{C}\left(26^{\prime}\right)-\mathrm{H}(26 \mathrm{D})$ & 109 \\
\hline $\mathrm{C}\left(24^{\prime}\right)-\mathrm{C}\left(26^{\prime}\right)-\mathrm{H}(26 \mathrm{E})$ & 105 \\
\hline $\mathrm{C}\left(24^{\prime}\right)-\mathrm{C}\left(26^{\prime}\right)-\mathrm{H}(26 \mathrm{~F})$ & $10 s$ \\
\hline $\mathrm{H}(26 \mathrm{D})-\mathrm{C}\left(26^{\prime}\right)-\mathrm{H}(26 \mathrm{E})$ & $10 s$ \\
\hline $\mathrm{H}(26 \mathrm{D})-\mathrm{C}\left(26^{\prime}\right)-\mathrm{H}(26 \mathrm{~F})$ & 100 \\
\hline $\mathrm{H}(26 \mathrm{E})-\mathrm{C}\left(26^{\prime}\right)-\mathrm{H}(26 \mathrm{~F})$ & 109 \\
\hline $\mathrm{C}(24)-\mathrm{C}(25)-\mathrm{H}(25 \mathrm{~A})$ & 100 \\
\hline $\mathrm{C}(24)-\mathrm{C}(25)-\mathrm{H}(25 \mathrm{~B})$ & 109. \\
\hline $\mathrm{C}(24)-\mathrm{C}(25)-\mathrm{H}(25 \mathrm{C})$ & 109.5 \\
\hline $\mathrm{H}(25 \mathrm{~A})-\mathrm{C}(25)-\mathrm{H}(25 \mathrm{~B})$ & 109. \\
\hline $\mathrm{H}(25 \mathrm{~A})-\mathrm{C}(25)-\mathrm{H}(25 \mathrm{C})$ & 109 \\
\hline $\mathrm{H}(25 \mathrm{~B})-\mathrm{C}(25)-\mathrm{H}(25 \mathrm{C})$ & 109 \\
\hline $\mathrm{C}(24)-\mathrm{C}(26)-\mathrm{H}(26 \mathrm{~A})$ & 109 \\
\hline $\mathrm{C}(24)-\mathrm{C}(26)-\mathrm{H}(26 \mathrm{~B})$ & 109 \\
\hline $\mathrm{C}(24)-\mathrm{C}(26)-\mathrm{H}(26 \mathrm{C})$ & 10 \\
\hline $\mathrm{H}(26 \mathrm{~A})-\mathrm{C}(26)-\mathrm{H}(26 \mathrm{~B})$ & 100 \\
\hline $\mathrm{H}(26 \mathrm{~A})-\mathrm{C}(26)-\mathrm{H}(26 \mathrm{C})$ & 109 \\
\hline $\mathrm{H}(26 \mathrm{~B})-\mathrm{C}(26)-\mathrm{H}(26 \mathrm{C})$ & 10 \\
\hline $\mathrm{C}\left(24^{\prime}\right)-\mathrm{C}\left(25^{\prime}\right)-\mathrm{H}(25 \mathrm{D})$ & 109 \\
\hline $\mathrm{C}\left(24^{\prime}\right)-\mathrm{C}\left(25^{\prime}\right)-\mathrm{H}(25 \mathrm{E})$ & 10 \\
\hline $\mathrm{C}\left(24^{\prime}\right)-\mathrm{C}\left(25^{\prime}\right)-\mathrm{H}(25 \mathrm{~F})$ & 105 \\
\hline $\mathrm{H}(25 \mathrm{D})-\mathrm{C}\left(25^{\prime}\right)-\mathrm{H}(25 \mathrm{E})$ & 109 \\
\hline
\end{tabular}




$\begin{array}{ll}\mathrm{H}(25 \mathrm{D})-\mathrm{C}\left(25^{\prime}\right)-\mathrm{H}(25 \mathrm{~F}) & 109.5 \\ \mathrm{H}(25 \mathrm{E})-\mathrm{C}\left(25^{\prime}\right)-\mathrm{H}(25 \mathrm{~F}) & 109.5 \\ \mathrm{C}\left(13^{\prime}\right)-\mathrm{C}\left(14^{\prime}\right)-\mathrm{H}(14 \mathrm{C}) & 120.0 \\ \mathrm{C}\left(13^{\prime}\right)-\mathrm{C}\left(14^{\prime}\right)-\mathrm{H}(14 \mathrm{D}) & 120.0 \\ \mathrm{H}(14 \mathrm{C})-\mathrm{C}\left(14^{\prime}\right)-\mathrm{H}(14 \mathrm{D}) & 120.0\end{array}$

Symmetry transformations used to generate equivalent atoms: 
Table 4. Anisotropic displacement parameters $\left(\AA^{2} \times 10^{3}\right)$ for micalizio22_0m_a. The anisotropic displacement factor exponent takes the form: $-2 \pi^{2}\left[h^{2} a^{* 2} U^{11}+\ldots+2 h k a^{*} b^{*} U^{12}\right]$

\begin{tabular}{|c|c|c|c|c|c|c|}
\hline & $\mathrm{U}^{11}$ & $\mathrm{U}^{22}$ & $\mathrm{U}^{33}$ & $\mathrm{U}^{23}$ & $\mathrm{U}^{13}$ & $\mathrm{U}^{12}$ \\
\hline $\operatorname{Si}(1)$ & $25(1)$ & $20(1)$ & $22(1)$ & $4(1)$ & $8(1)$ & $1(1)$ \\
\hline $\operatorname{Si}\left(1^{\prime}\right)$ & $25(1)$ & 21(1) & $25(1)$ & $2(1)$ & $7(1)$ & $2(1)$ \\
\hline $\mathrm{O}\left(2^{\prime}\right)$ & $18(1)$ & $26(1)$ & $17(1)$ & $-1(1)$ & $7(1)$ & $3(1)$ \\
\hline $\mathrm{O}(2)$ & $21(1)$ & $18(1)$ & 21(1) & $-1(1)$ & 11(1) & $-1(1)$ \\
\hline $\mathrm{O}(1)$ & $23(1)$ & $17(1)$ & $22(1)$ & $4(1)$ & $8(1)$ & $3(1)$ \\
\hline $\mathrm{O}(6)$ & $21(1)$ & $27(1)$ & $22(1)$ & $4(1)$ & $8(1)$ & $-6(1)$ \\
\hline $\mathrm{O}\left(3^{\prime}\right)$ & $21(1)$ & $28(1)$ & $23(1)$ & $4(1)$ & $0(1)$ & $0(1)$ \\
\hline $\mathrm{O}(3)$ & $24(1)$ & $26(1)$ & $25(1)$ & $-2(1)$ & $9(1)$ & $-7(1)$ \\
\hline $\mathrm{O}(4)$ & $17(1)$ & $25(1)$ & $23(1)$ & $-2(1)$ & $7(1)$ & $-1(1)$ \\
\hline $\mathrm{O}\left(4^{\prime}\right)$ & $16(1)$ & $28(1)$ & $22(1)$ & $0(1)$ & $4(1)$ & $1(1)$ \\
\hline $\mathrm{O}(5)$ & $27(1)$ & $32(1)$ & $23(1)$ & $-2(1)$ & $16(1)$ & $-3(1)$ \\
\hline $\mathrm{O}\left(1^{\prime}\right)$ & $21(1)$ & $21(1)$ & $22(1)$ & $2(1)$ & $9(1)$ & $1(1)$ \\
\hline $\mathrm{O}\left(5^{\prime}\right)$ & $22(1)$ & $38(1)$ & $34(1)$ & $-13(1)$ & $8(1)$ & $8(1)$ \\
\hline $\mathrm{O}\left(6^{\prime}\right)$ & $22(1)$ & $22(1)$ & $36(1)$ & $-2(1)$ & $3(1)$ & $4(1)$ \\
\hline$C(6)$ & $19(1)$ & $20(1)$ & $22(1)$ & $3(1)$ & $8(1)$ & $-2(1)$ \\
\hline $\mathrm{C}\left(20^{\prime}\right)$ & $16(1)$ & $23(1)$ & $18(1)$ & $1(1)$ & $5(1)$ & $2(1)$ \\
\hline$C\left(6^{\prime}\right)$ & $18(1)$ & $21(1)$ & $28(1)$ & $0(1)$ & $5(1)$ & $3(1)$ \\
\hline$C\left(4^{\prime}\right)$ & $20(1)$ & $26(1)$ & $18(1)$ & $2(1)$ & $1(1)$ & $-2(1)$ \\
\hline $\mathrm{C}(28)$ & $22(1)$ & $21(1)$ & $29(1)$ & $-2(1)$ & $9(1)$ & $-4(1)$ \\
\hline$C(4)$ & $21(1)$ & $22(1)$ & $26(1)$ & $-4(1)$ & $10(1)$ & $-5(1)$ \\
\hline $\mathrm{C}(21)$ & $19(1)$ & $15(1)$ & $22(1)$ & $2(1)$ & $8(1)$ & $1(1)$ \\
\hline $\mathrm{C}\left(21^{\prime}\right)$ & $18(1)$ & $22(1)$ & $18(1)$ & $2(1)$ & $6(1)$ & $2(1)$ \\
\hline$C(17)$ & $18(1)$ & $19(1)$ & $19(1)$ & $0(1)$ & $7(1)$ & $2(1)$ \\
\hline$C(20)$ & $18(1)$ & $19(1)$ & $20(1)$ & $0(1)$ & $7(1)$ & $-1(1)$ \\
\hline$C(8)$ & $24(1)$ & $29(1)$ & $25(1)$ & $3(1)$ & $6(1)$ & $-1(1)$ \\
\hline $\mathrm{C}(19)$ & $18(1)$ & $24(1)$ & $17(1)$ & $-1(1)$ & $7(1)$ & $-2(1)$ \\
\hline$C(10)$ & $22(1)$ & $24(1)$ & $19(1)$ & $0(1)$ & $10(1)$ & $-1(1)$ \\
\hline$C(7)$ & $20(1)$ & $24(1)$ & $22(1)$ & $3(1)$ & $10(1)$ & $-4(1)$ \\
\hline $\mathrm{C}\left(19^{\prime}\right)$ & $17(1)$ & $22(1)$ & $17(1)$ & $-3(1)$ & $4(1)$ & $0(1)$ \\
\hline$C\left(7^{\prime}\right)$ & $19(1)$ & $21(1)$ & $36(1)$ & $-4(1)$ & $6(1)$ & $3(1)$ \\
\hline $\mathrm{C}(18)$ & $17(1)$ & $20(1)$ & 19(1) & $0(1)$ & $7(1)$ & $0(1)$ \\
\hline
\end{tabular}




\begin{tabular}{|c|c|c|c|c|c|c|}
\hline$C\left(28^{\prime}\right)$ & $22(1)$ & $27(1)$ & $25(1)$ & $4(1)$ & $3(1)$ & $-1(1)$ \\
\hline$C\left(16^{\prime}\right)$ & $22(1)$ & $39(1)$ & $18(1)$ & 1(1) & $9(1)$ & $4(1)$ \\
\hline$C\left(8^{\prime}\right)$ & $29(1)$ & $27(1)$ & $46(2)$ & $-8(1)$ & $10(1)$ & $-4(1)$ \\
\hline$C\left(10^{\prime}\right)$ & $20(1)$ & $29(1)$ & $27(1)$ & $-9(1)$ & $6(1)$ & $4(1)$ \\
\hline$C\left(17^{\prime}\right)$ & $17(1)$ & $26(1)$ & $16(1)$ & $-3(1)$ & $5(1)$ & $2(1)$ \\
\hline$C(16)$ & $24(1)$ & $23(1)$ & $26(1)$ & $-2(1)$ & 11(1) & $2(1)$ \\
\hline$C(11)$ & $28(1)$ & $29(1)$ & $16(1)$ & $1(1)$ & $6(1)$ & $-4(1)$ \\
\hline$C\left(18^{\prime}\right)$ & $17(1)$ & $23(1)$ & $19(1)$ & $-1(1)$ & $4(1)$ & $1(1)$ \\
\hline$C\left(11^{\prime}\right)$ & $23(1)$ & $33(1)$ & $31(1)$ & $-13(1)$ & $6(1)$ & $3(1)$ \\
\hline$C(24)$ & $32(1)$ & $26(1)$ & $34(1)$ & $10(1)$ & $7(1)$ & $9(1)$ \\
\hline$C\left(2^{\prime}\right)$ & $27(1)$ & $37(1)$ & $13(1)$ & $0(1)$ & $4(1)$ & $-3(1)$ \\
\hline$C\left(24^{\prime}\right)$ & $37(1)$ & $27(1)$ & $40(1)$ & $3(1)$ & $12(1)$ & $-7(1)$ \\
\hline$C\left(1^{\prime}\right)$ & $39(1)$ & $37(1)$ & $20(1)$ & $-7(1)$ & $10(1)$ & $-5(1)$ \\
\hline$C(1)$ & $38(1)$ & $37(1)$ & $40(1)$ & $-15(1)$ & $22(1)$ & $-2(1)$ \\
\hline$C(2)$ & $34(1)$ & $24(1)$ & $31(1)$ & $-11(1)$ & $16(1)$ & $-8(1)$ \\
\hline$C(9)$ & $30(1)$ & $36(1)$ & $37(1)$ & $14(1)$ & $7(1)$ & $2(1)$ \\
\hline$C(13)$ & $47(1)$ & $38(1)$ & $30(1)$ & $-10(1)$ & $12(1)$ & $-11(1)$ \\
\hline$C\left(12^{\prime}\right)$ & $32(1)$ & $38(1)$ & $42(2)$ & $-17(1)$ & $5(1)$ & $4(1)$ \\
\hline$C\left(5^{\prime}\right)$ & $43(1)$ & $29(1)$ & $33(1)$ & $8(1)$ & 11(1) & $-4(1)$ \\
\hline$C\left(23^{\prime}\right)$ & $28(1)$ & $32(1)$ & $63(2)$ & $9(1)$ & $4(1)$ & $5(1)$ \\
\hline$C(12)$ & $39(1)$ & $34(1)$ & $29(1)$ & $-8(1)$ & $13(1)$ & $-6(1)$ \\
\hline$C(23)$ & $34(1)$ & $37(1)$ & $46(2)$ & $14(1)$ & $12(1)$ & $-5(1)$ \\
\hline$C(5)$ & $41(1)$ & $19(1)$ & $41(1)$ & $0(1)$ & $18(1)$ & $2(1)$ \\
\hline$C(3)$ & $40(1)$ & $48(2)$ & $25(1)$ & $-13(1)$ & $14(1)$ & $-6(1)$ \\
\hline$C\left(13^{\prime}\right)$ & $34(1)$ & $46(2)$ & $41(2)$ & $-21(1)$ & $7(1)$ & $-2(1)$ \\
\hline$C\left(3^{\prime}\right)$ & $31(1)$ & $59(2)$ & $20(1)$ & $-7(1)$ & $10(1)$ & $-8(1)$ \\
\hline$C(15)$ & $48(2)$ & $40(2)$ & $36(2)$ & $-12(1)$ & $9(1)$ & $-9(1)$ \\
\hline$C(22)$ & $60(2)$ & $34(1)$ & $26(1)$ & $4(1)$ & $18(1)$ & $7(1)$ \\
\hline$C\left(27^{\prime}\right)$ & $62(2)$ & $40(2)$ & $50(2)$ & $12(1)$ & $32(2)$ & $4(1)$ \\
\hline$C\left(9^{\prime}\right)$ & $49(2)$ & $26(1)$ & $54(2)$ & $-8(1)$ & $18(1)$ & $-10(1)$ \\
\hline$C(27)$ & $49(2)$ & $26(1)$ & $55(2)$ & $3(1)$ & $18(1)$ & $14(1)$ \\
\hline$C\left(15^{\prime}\right)$ & $52(2)$ & $53(2)$ & $40(2)$ & $-16(1)$ & $8(1)$ & $0(1)$ \\
\hline$C\left(22^{\prime}\right)$ & $76(2)$ & $31(1)$ & $38(2)$ & $0(1)$ & $24(1)$ & $15(1)$ \\
\hline$C(14)$ & $58(2)$ & $81(2)$ & $35(2)$ & $-19(2)$ & $15(1)$ & $-28(2)$ \\
\hline$C\left(26^{\prime}\right)$ & $76(2)$ & $27(1)$ & $66(2)$ & $2(1)$ & $31(2)$ & $-11(1)$ \\
\hline$C(25)$ & $27(1)$ & $51(2)$ & $62(2)$ & $6(1)$ & $1(1)$ & $7(1)$ \\
\hline
\end{tabular}




\begin{tabular}{lllllll}
$\mathrm{C}(26)$ & $55(2)$ & $47(2)$ & $49(2)$ & $28(1)$ & $14(1)$ & $21(1)$ \\
$\mathrm{C}\left(25^{\prime}\right)$ & $36(2)$ & $71(2)$ & $83(3)$ & $8(2)$ & $6(2)$ & $-23(2)$ \\
$\mathrm{C}\left(14^{\prime}\right)$ & $43(2)$ & $101(3)$ & $91(3)$ & $-67(2)$ & $-9(2)$ & $12(2)$ \\
\hline
\end{tabular}


Table 5. Hydrogen coordinates ( $\left.\times 10^{4}\right)$ and isotropic displacement parameters $\left(\AA^{2} \times 10^{3}\right)$ for micalizio22_0m_a.

\begin{tabular}{|c|c|c|c|c|}
\hline & $\mathrm{x}$ & $\mathrm{y}$ & $\mathrm{z}$ & $\mathrm{U}(\mathrm{eq})$ \\
\hline $\mathrm{H}(4)$ & -2285 & 2957 & 2831 & 33 \\
\hline $\mathrm{H}\left(4^{\prime}\right)$ & 2692 & 3003 & 2732 & 33 \\
\hline $\mathrm{H}(5)$ & -1233 & 3195 & 4386 & 38 \\
\hline $\mathrm{H}\left(5^{\prime}\right)$ & 3594 & 3806 & 3950 & 47 \\
\hline $\mathrm{H}(20 \mathrm{C})$ & 6762 & 3121 & 3762 & 23 \\
\hline $\mathrm{H}(20 \mathrm{D})$ & 6783 & 2759 & 4412 & 23 \\
\hline $\mathrm{H}(21)$ & 1810 & 3833 & 2581 & 22 \\
\hline $\mathrm{H}\left(21^{\prime}\right)$ & 7230 & 2266 & 3550 & 23 \\
\hline $\mathrm{H}(20 \mathrm{~A})$ & 1482 & 4029 & 3641 & 23 \\
\hline $\mathrm{H}(20 \mathrm{~B})$ & 1683 & 3418 & 3594 & 23 \\
\hline $\mathrm{H}(8)$ & 2182 & 2530 & 4598 & 31 \\
\hline $\mathrm{H}(19)$ & -1142 & 3290 & 1972 & 23 \\
\hline $\mathrm{H}\left(19^{\prime}\right)$ & 4141 & 2290 & 2560 & 23 \\
\hline $\mathrm{H}(16 \mathrm{D})$ & 4441 & 2338 & 4186 & 38 \\
\hline $\mathrm{H}(16 \mathrm{E})$ & 3872 & 2850 & 4405 & 38 \\
\hline $\mathrm{H}(16 \mathrm{~F})$ & 5165 & 2676 & 4836 & 38 \\
\hline $\mathrm{H}\left(8^{\prime}\right)$ & 6723 & 4257 & 3506 & 41 \\
\hline $\mathrm{H}(16 \mathrm{~A})$ & -215 & 4385 & 3751 & 35 \\
\hline $\mathrm{H}(16 \mathrm{~B})$ & -1323 & 4049 & 3790 & 35 \\
\hline $\mathrm{H}(16 \mathrm{C})$ & -1134 & 4184 & 3052 & 35 \\
\hline $\mathrm{H}(11 \mathrm{~A})$ & 2028 & 3526 & 4684 & 29 \\
\hline $\mathrm{H}(11 \mathrm{~B})$ & 1514 & 3294 & 5273 & 29 \\
\hline $\mathrm{H}(11 \mathrm{C})$ & 6324 & 3483 & 5065 & 35 \\
\hline $\mathrm{H}(11 \mathrm{D})$ & 6940 & 3750 & 4542 & 35 \\
\hline $\mathrm{H}\left(2^{\prime}\right)$ & 4267 & 2876 & 887 & 31 \\
\hline $\mathrm{H}\left(1^{\prime} \mathrm{A}\right)$ & 4673 & 1890 & 1563 & 47 \\
\hline $\mathrm{H}\left(1^{\prime} \mathrm{B}\right)$ & 4315 & 1983 & 741 & 47 \\
\hline $\mathrm{H}\left(1^{\prime} \mathrm{C}\right)$ & 3401 & 2109 & 1168 & 47 \\
\hline $\mathrm{H}(1 \mathrm{~A})$ & 1286 & 2660 & 1542 & 54 \\
\hline $\mathrm{H}(1 \mathrm{~B})$ & 1173 & 2080 & 1240 & 54 \\
\hline
\end{tabular}




\begin{tabular}{|c|c|c|c|c|}
\hline $\mathrm{H}(1 \mathrm{C})$ & 1508 & 2174 & 2061 & 54 \\
\hline $\mathrm{H}(2)$ & -499 & 1925 & 1547 & 34 \\
\hline $\mathrm{H}(9 \mathrm{~A})$ & 532 & 1877 & 4900 & 42 \\
\hline $\mathrm{H}(9 \mathrm{~B})$ & 1964 & 1812 & 5169 & 42 \\
\hline $\mathrm{H}(12 \mathrm{C})$ & 6007 & 4549 & 4659 & 46 \\
\hline $\mathrm{H}(12 \mathrm{D})$ & 5448 & 4279 & 5205 & 46 \\
\hline $\mathrm{H}\left(5^{\prime} \mathrm{A}\right)$ & 4555 & 3769 & 1151 & 53 \\
\hline $\mathrm{H}\left(5^{\prime} \mathrm{B}\right)$ & 5539 & 3987 & 1812 & 53 \\
\hline $\mathrm{H}\left(5^{\prime} \mathrm{C}\right)$ & 4222 & 4196 & 1643 & 53 \\
\hline $\mathrm{H}(23 \mathrm{D})$ & 8352 & 1476 & 4065 & 65 \\
\hline $\mathrm{H}(23 \mathrm{E})$ & 8085 & 903 & 4289 & 65 \\
\hline $\mathrm{H}(23 \mathrm{~F})$ & 7870 & 1395 & 4724 & 65 \\
\hline $\mathrm{H}(12 \mathrm{~A})$ & 1346 & 4344 & 4797 & 40 \\
\hline $\mathrm{H}(12 \mathrm{~B})$ & 467 & 4136 & 5210 & 40 \\
\hline $\mathrm{H}(23 \mathrm{~A})$ & 1758 & 5146 & 2255 & 58 \\
\hline $\mathrm{H}(23 \mathrm{~B})$ & 1925 & 5055 & 1500 & 58 \\
\hline $\mathrm{H}(23 \mathrm{C})$ & 2462 & 4648 & 2112 & 58 \\
\hline $\mathrm{H}(5 \mathrm{~A})$ & -17 & 1554 & 3389 & 49 \\
\hline $\mathrm{H}(5 \mathrm{~B})$ & 1155 & 1770 & 3252 & 49 \\
\hline $\mathrm{H}(5 \mathrm{C})$ & 147 & 1522 & 2627 & 49 \\
\hline $\mathrm{H}(3 \mathrm{~A})$ & -1820 & 2543 & 900 & 55 \\
\hline $\mathrm{H}(3 \mathrm{~B})$ & -880 & 2380 & 506 & 55 \\
\hline $\mathrm{H}(3 \mathrm{C})$ & -755 & 2924 & 908 & 55 \\
\hline $\mathrm{H}\left(3^{\prime} \mathrm{A}\right)$ & 6295 & 3044 & 1485 & 54 \\
\hline $\mathrm{H}\left(3^{\prime} \mathrm{B}\right)$ & 6110 & 2606 & 897 & 54 \\
\hline $\mathrm{H}\left(3^{\prime} \mathrm{C}\right)$ & 6433 & 2443 & 1699 & 54 \\
\hline $\mathrm{H}(15 \mathrm{~A})$ & 3584 & 3956 & 5504 & 63 \\
\hline $\mathrm{H}(15 \mathrm{~B})$ & 3942 & 4231 & 6251 & 63 \\
\hline $\mathrm{H}(15 \mathrm{C})$ & 3462 & 4573 & 5562 & 63 \\
\hline $\mathrm{H}(22 \mathrm{~A})$ & 1125 & 3806 & 1114 & 58 \\
\hline $\mathrm{H}(22 \mathrm{~B})$ & 619 & 4253 & 555 & 58 \\
\hline $\mathrm{H}(22 \mathrm{C})$ & -258 & 3865 & 779 & 58 \\
\hline $\mathrm{H}(27 \mathrm{D})$ & 6126 & 1055 & 5087 & 71 \\
\hline $\mathrm{H}(27 \mathrm{E})$ & 4778 & 904 & 4955 & 71 \\
\hline $\mathrm{H}(27 \mathrm{~F})$ & 5127 & 1477 & 4774 & 71 \\
\hline $\mathrm{H}\left(9^{\prime} \mathrm{A}\right)$ & 4763 & 4829 & 2801 & 50 \\
\hline
\end{tabular}




\begin{tabular}{|c|c|c|c|c|}
\hline $\mathrm{H}\left(9^{\prime} \mathrm{B}\right)$ & 6139 & 5011 & 2973 & 50 \\
\hline $\mathrm{H}(27 \mathrm{~A})$ & -895 & 5073 & 2447 & 64 \\
\hline $\mathrm{H}(27 \mathrm{~B})$ & -1555 & 5521 & 1928 & 64 \\
\hline $\mathrm{H}(27 \mathrm{C})$ & -155 & 5498 & 2169 & 64 \\
\hline $\mathrm{H}(15 \mathrm{D})$ & 6665 & 5185 & 5706 & 74 \\
\hline $\mathrm{H}(15 \mathrm{E})$ & 7700 & 4997 & 6361 & 74 \\
\hline $\mathrm{H}(15 \mathrm{~F})$ & 6392 & 4796 & 6262 & 74 \\
\hline $\mathrm{H}(22 \mathrm{D})$ & 5418 & 1170 & 2487 & 70 \\
\hline $\mathrm{H}(22 \mathrm{E})$ & 6479 & 771 & 2771 & 70 \\
\hline $\mathrm{H}(22 \mathrm{~F})$ & 6739 & 1361 & 2607 & 70 \\
\hline $\mathrm{H}(14 \mathrm{~A})$ & 2540 & 4197 & 6849 & 69 \\
\hline $\mathrm{H}(14 \mathrm{~B})$ & 1145 & 4118 & 6434 & 69 \\
\hline $\mathrm{H}(26 \mathrm{D})$ & 5548 & 226 & 3592 & 81 \\
\hline $\mathrm{H}(26 \mathrm{E})$ & 5033 & 145 & 4238 & 81 \\
\hline $\mathrm{H}(26 \mathrm{~F})$ & 6383 & 293 & 4368 & 81 \\
\hline $\mathrm{H}(25 \mathrm{~A})$ & -2019 & 4369 & 858 & 73 \\
\hline $\mathrm{H}(25 \mathrm{~B})$ & -2708 & 4825 & 1116 & 73 \\
\hline $\mathrm{H}(25 \mathrm{C})$ & -2027 & 4392 & 1654 & 73 \\
\hline $\mathrm{H}(26 \mathrm{~A})$ & -183 & 5485 & 895 & 76 \\
\hline $\mathrm{H}(26 \mathrm{~B})$ & -1582 & 5511 & 683 & 76 \\
\hline $\mathrm{H}(26 \mathrm{C})$ & -946 & 5054 & 389 & 76 \\
\hline $\mathrm{H}(25 \mathrm{D})$ & 3833 & 1385 & 3550 & 98 \\
\hline $\mathrm{H}(25 \mathrm{E})$ & 3466 & 829 & 3777 & 98 \\
\hline $\mathrm{H}(25 \mathrm{~F})$ & 3943 & 878 & 3111 & 98 \\
\hline $\mathrm{H}(14 \mathrm{C})$ & 8846 & 4343 & 6142 & 101 \\
\hline $\mathrm{H}(14 \mathrm{D})$ & 8350 & 3930 & 5499 & 101 \\
\hline
\end{tabular}




\section{References}

1. Love, B.; Jones, E. J. Org. Chem. 1999, 64, 10, 3755

2. Zhang, X.-B.; Lu, Z.; Fu, C.-L.; Ma, S.-M. Org. Biomol. Chem. 2009, 7, 3258

3. Du, K.; Kier, M. J.; Rheingold, A. L. Micalizio, G. C. Org. Lett. 2018, 20, 6457

4. Hayes, P. Y.; Kitching, W. J. Am. Chem. Soc. 2002, 124, 9718

5. Buffet, M. F.; Dixon, D.; Ley, S. V.; Reynolds, D. J. Storer, R. I. Org. Biomol. Chem. 2004, 2, 1145

6. Hookins, D. R.; Burns, A. R.; Taylor, R. J. K.; Eur. J. Org. Chem. 2011, 451

7. Han, A.; Tao, Y.-J.; Reisman, S. E. Nature 2019, 573, 563

8. a) Kanda, Y.; Nakamura, H.; Umemiya, S.; Puthukanoori, R. K.; Appala, V. R. M.; Gaddamanugu, G. K.; Paraselli, B. R.; Baran, P. S. J. Am. Chem. Soc. 2020, 142, 10526;

b) Gao, J.-H.; Rao, P.-R.; Xu, K.-X.; Wang, S.-F.; Wu, Y.-F.; He, C.; Ding, H.-F. J. Am. Chem. Soc. 2020, 142, 4592

9. Chuang, K. V.; Xu, C.; Reisman, S. E. Science 2016, 353, 912 